UNIVERSIDADE DE SÃO PAULO

INSTITUTO DE GEOCIÊNCIAS

\title{
QUALIDADE FÍSICA E QUÍMICA DA ÁGUA E SEDIMENTOS DE FUNDO DA PORÇÃO SW DO RESERVATÓRIO DE BIRITIBA-MIRIM (SP) E SUA IMPLICAÇÃO AMBIENTAL
}

\author{
Ana Carolina Sartori \\ Orientador: Prof. Dr. Joel Barbujiani Sígolo \\ DISSERTAÇÃO DE MESTRADO
}

Programa de Pós-Graduação em Recursos Minerais e Hidrogeologia

Versão Corrigida

São Paulo

2015 
ANA CAROLINA SARTORI

QUALIDADE FÍSICA E QUÍMICA DA ÁGUA E SEDIMENTOS DE FUNDO DA PORÇÃO SW DO RESERVATÓRIO DE BIRITIBA-MIRIM (SP) E SUA IMPLICAÇÃO AMBIENTAL

Dissertação apresentada ao

Instituto de Geociências da

Universidade de São Paulo

para a obtenção do título de

Mestre.

Área de Concentração:

Recursos Minerais e

Hidrogeologia.

Orientador: Prof. Dr. Joel

Barbujiani Sígolo.

Versão Corrigida

São Paulo

2015 
Autorizo a reprodução e divulgação total ou parcial deste trabalho, por qualquer meio convencional ou eletrônico, para fins de estudo e pesquisa, desde que citada a fonte.

Ficha catalográfica preparada pelo Serviço de Biblioteca e Documentação do Instituto de Geociências da Universidade de São Paulo

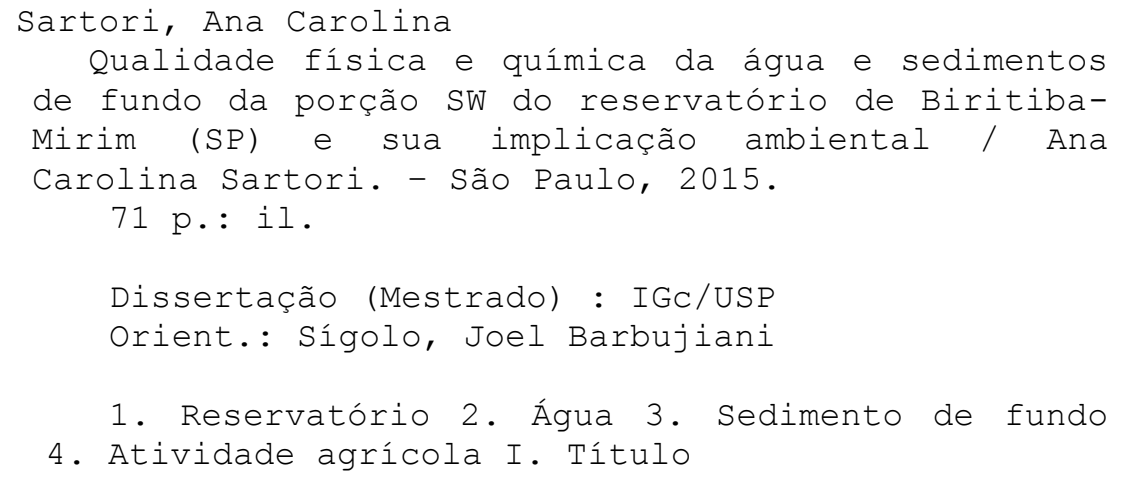


Dedico esse trabalho a minha família, pelo incentivo e apoio em todas as minhas escolhas e decisões.

A vitória dessa conquista dedico ao meu marido, Daniel. 


\section{AGRADECIMENTOS}

Ao meu Deus, pelo presente da vida, pelo alento que respiro, pelas pessoas que convivo, pela graça de ter me permitido concluir essa dissertação, pelo dom do ensino, pelo cuidado diário e amor supremo.

Ao Prof. Dr. Joel Barbujiani Sígolo, pela orientação e amizade e por sempre ter acreditado em minha capacidade e potencial para a realização dessa dissertação. Obrigada pelo carinho pelas pessoas que te cercam.

Agradecimento especial a minha mãe, pela coragem e esforço, por nossa educação e princípios.

Ao meu marido Daniel, pela parceria, carinho, força sempre, além da ajuda na reta final desse Mestrado.

Aos colegas de pesquisa, Edvaldo Sorrini e Camila Sousa. Pela companhia nos estudos do meio e a partilha de informações, sempre enriquecedoras.

Aos Laboratórios de granulometria de sedimentos do Instituto de Geociências e seus respectivos funcionários; À Sabesp, pelos equipamentos de infraestrutura para coleta de amostras e análise química da água. Ao Laboratório de caracterização tecnológica (LCT) da Escola Politécnica da Universidade de São Paulo, o qual realizou a determinação de diversos elementos químicos. Obrigada pela participação indispensável nesse trabalho.

Ao Conselho Nacional de Desenvolvimento Científico e Tecnológico - CNPq pelo apoio financeiro durante o desenvolvimento desse trabalho.

A minha família, pelo apoio e amor incondicional. 
"É muito melhor lançar-se em busca de conquistas grandiosas, mesmo expondo-se ao fracasso, do que alinhar-se com os pobres de espírito, que nem gozam muito nem sofrem muito, porque vivem numa penumbra cinzenta, onde não conhecem nem vitória, nem derrota."

Theodore Roosevelt 


\section{RESUMO}

Essa dissertação teve como objetivo principal comparar parâmetros físicos e químicos da água e sedimentos de fundo em dez pontos delimitados do reservatório de Biritiba-Mirim, uma próxima à atividade agrícola e outra em que havia proteção de mata nativa. Como objetivo secundário, avaliar o uso e ocupação do solo no entorno do reservatório, utilizando imagens obtidas por sensoriamento remoto e também, discutir os parâmetros utilizados para delimitar a qualidade da água e sedimentos de fundo balizados pelos critérios do CONAMA, CETESB e MINISTÉRIO DA SAÚDE. A qualidade da água e sedimentos de fundo do reservatório foi determinada com base na coleta e análise laboratorial das amostras. Os resultados obtidos evidenciam variações nos parâmetros físico-químicos da água, pH e OD. As amostras CAL estão dentro dos valores referenciados pelos critérios estudados, mas algumas amostras CAS e os pontos de referência apresentaram os elementos alumínio, ferro e manganês em concentração acima do valor permitido pelas normativas em questão. As amostras CAL apresentaram-se mais com maior quantidade dos elementos químicos: fósforo, enxofre, potássio, manganês, cobre, zinco e chumbo do que as amostras CAS. Nas duas amostras retiradas do ponto de referência, o esperado era não encontrar os elementos químicos fósforo, enxofre e cobre. A análise das imagens de uso e ocupação do solo por sensoriamento remoto exibiu um aumento considerável da área de horticultura, ao mesmo tempo que apresentou diminuição das áreas cobertas de vegetação. Conclui-se que a alteração do $\mathrm{pH}$ e $\mathrm{OD}$, assim como a presença de alumínio, ferro e manganês em concentrações acima do valor permitido na amostras CAS e ponto referência da água, pode estar relacionado ao despejo de aditivos agrícolas. Pode ser que devido a presença e quantidade de elementos químicos presentes no sedimento de fundo não haja comprometimento ambiental. Para evitarmos o comprometimento da água e solo dos reservatórios destinados a captação de água e, consequentemente, o desabastecimento das grandes cidades, como o que vem acontecendo nos anos de 2014 e 2015, deve haver uma melhor gestão dos recursos hídricos, que proiba o manejo inadequado do solo e que proteja as áreas de mananciais e a mata ciliar do entorno dos reservatórios.

Palavras-chave: reservatório; água; sedimento de fundo; atividade agrícola. 


\section{ABSTRACT}

This dissertation aimed to compare physical and chemical parameters of water and bottom sediments in ten delimited points Biritiba-Mirim reservoir, one next to agriculture and one where there were native forest protection. As a secondary objective, to evaluate the use and occupation of land around the reservoir, using images obtained by remote sensing, and also discuss the parameters used to define the quality of water and bottom sediments marked by CONAMA criteria, CETESB and MINISTRY OF HEALTH. The water quality and bottom sediments was determined based on the collection and laboratory analysis of samples that were sent for chemical analysis. The results show variations in physical and chemical parameters of water, $\mathrm{pH}$ and OD. The CAL samples are within the range referenced by the criteria studied, but some CAS samples and reference samples presented the elements aluminum, iron and manganese in concentrations above the amount permitted by the regulations in question. The CAL samples that had become more enriched by chemical elements phosphorus, sulfur, potassium, manganese, copper, zinc and lead than CAS samples. In both samples taken from the reference point, it wasn't expected to find chemical elements phosphorus, sulfur and copper. The analysis of land use and occupation by remote sensing images showed a considerable increase in the horticultural area, while presented decrease in areas covered by vegetation. It is concluded that the change in $\mathrm{pH}$ and $\mathrm{OD}$, as well as the presence of aluminum, iron and manganese in concentrations above the permitted value in the CAS sample and reference point of water, may be related to the presence of agricultural additives. It may be that due to the presence and amount of chemical elements present in the bottom sediment there is no environmental impairment. To avoid compromising the water and soil of the reservoires intended for the abstraction of water and hence the shortage of large cities such as what happened in the years 2014 and 2015, there should be a better management of water resources, which prohibit inadequate management of soil and protect the watershed areas and riparian forest surrounding the reservoirs.

Keywords: reservoir; water; bottom sediment; agricultural activity. 


\section{LISTA DE FIGURAS}

Figura 1 - Bacia hidrográfica do Alto Tietê e indicação (seta vermelha) do Reservatório estudado

Figura 2 - Localização do município de Biritiba Mirim no Estado de São Paulo e rodovias de acesso até o reservatório de Biritiba-Mirim

Figura 3 - Foto com a vista do reservatório de Biritiba-Mirim.

Figura 4 - Intensidades de chuva mensais e anuais no Reservatório de Biritiba Mirim. O eixo das ordenadas representa a precipitação $(\mathrm{mm})$ e o eixo das abcissas os meses do ano

Figura 5 - Unidades geológicas aflorantes na área do reservatório de Biritiba-Mirim. (Fonte: Monteiro, 2006).

Figura 6 - Mapa hidrogeológico da área de estudo 25

Figura 7 - Unidades geomorfológicas presentes na área de estudo .28

Figura 8 - Imagens da Sonda Multiparâmetro Modelo YSI 6820 V2, para determinação de parâmetros "in situ" na Represa Biritiba-Mirim 30

Figura 9 - Pesagem das amostras úmidas de sedimentos de fundo

Figura 10 - Amostras úmidas de sedimento de fundo em estufa à $60{ }^{\circ} \mathrm{C}$ ) para a secagem (peso seco)

Figura 11- Ataque à matéria orgânica presente nas amostras de sedimento de fundo após a adição de água oxigenada.

Figura 12 - Granulometria à laser - Malveer Master

Figura 13 - Equipamento ICP OES

Figura 14 - Equipamento DR5000

Figura 15 - Mapa de localização das áreas de amostragens no reservatório BiritibaMirim distanciadas em cerca de 5 metros da margem todas georeferenciadas (indicados em vermelho os locais de coleta das amostras) .36 
Figura 16 - Ponto de referência de coleta da SABESP (visão para Leste)

Figura 17 - Área de coleta de amostras de água e sedimentos de fundo, expondo a visão lateral para o Norte.

Figura 18 - Área de coleta de amostras de água e sedimentos de fundo, expondo a visão lateral para o Sul.

Figura 19 - Área de coleta de amostras de água e sedimentos de fundo, expondo a visão frontal -1 .

Figura 20 - Área de coleta de amostras de água e sedimentos de fundo, exibindo a visão frontal -2 .

Figura 21 - Sonda Multiparâmetro - Modelo YSI 6820 V2.......................................38

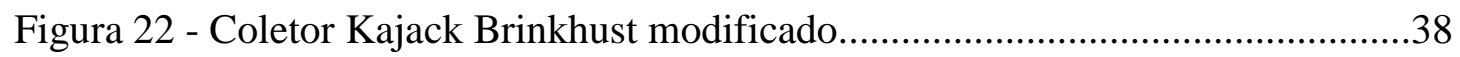

Figura 23 - Fixação do coletor Kajack Brinkhust para a coleta de água e sedimento de fundo. .38

Figura 24 - Coleta de água e sedimentos de fundo... 39

Figura 25 - Porção final do coletor Kajack Brinkhust contendo o sedimento e a água de fundo do reservatório.

Figura 26 - Extração do sedimento de fundo. .39

Figura 27 - Diagrama que representa os elementos químicos e suas quantidades relativas encontradas nas amostras retiradas da área do reservatório, circundada por mata preservada.

Figura 28 - Diagrama que representa os elementos químicos e suas quantidades encontradas nas amostras retiradas da área do reservatório circundada por atividade agrícola.

Figura 29 - Diagrama que representa os elementos químicos e suas quantidades encontradas nas amostras retiradas do ponto considerado de referência (ponto referência).

Figura 30 - Composição colorida da Bacia Hidrográfica do Alto Tietê, ano de 1990 .

Figura 31 - Composição colorida da Bacia Hidrográfica do Alto Tietê, ano de 2011.

Figura 32 - Representação da digitalização dos reservatórios da Bacia Hidrográfica do Alto Tietê 
Figura 33 - Classificação supervisionada da Bacia hidrográfica do Alto Tietê, ano de 1990. Os contornos em preto mostram qual será a área preenchida de água de cada

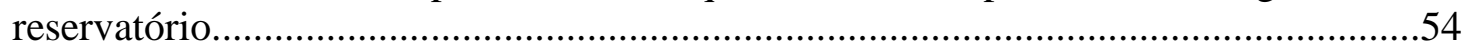

Figura 34 - Classificação supervisionada da Bacia Hidrográfica do Alto Tietê, ano de 2011. 55

Figura 35 - Zonação longitudinal do reservatório. (modificado de COOKE et. al., 2005)..... 61 


\section{LISTA DE TABELAS}

Tabela 1 - Valores máximos dos parâmetros químicos da água para consumo humano, somente com os elementos químicos analisados nessa dissertação. Os espaços expressos através de (-) mostram que o parâmetro analisado não trata dos elementos

em

estudo.

Tabela 2 - Índices de qualidade da água e respectivas variáveis que os integram)

Tabela 3 - Classificação da qualidade de elementos em sedimentos analisados nessa dissertação a partir de TEL e PEL

Tabela 4 - Bandas espectrais do TM/LANDSAT 5 com suas aplicações, utilizadas na

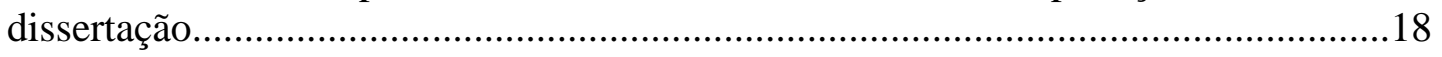

Tabela 5 - Características do reservatório de Biritiba-Mirim ...................................19

Tabela 6 - Identificação dos vetores através da digitalização dos indicadores quantitativos da água dos reservatório.

Tabela 7 - Identificação das classes de desejo para a classificação supervisionada das imagens.

Tabela 8 - Valores dos parâmetros físico-químicos da água da porção SW do Reservatório de Biritiba-Mirim(SP) em área protegida por área preservada. 41

Tabela 9 - Valores dos parâmetros físico-químicos da água da porção SW do Reservatório de Biritiba-Mirim(SP) em área próxima ao reservatório com atividade agrícola.

Tabela 10 - Valores dos parâmetros físico-químicos da cabeceira do Ribeirão Biritiba-Mirim(SP), valores de referência.

Tabela 11 - Teor em massa e teor de umidade de cada

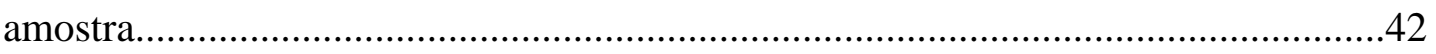

Tabela 12 - Porcentagem de matéria orgânica presente nas amostras.........................43

Tabela 13a - Resultados de análise granulométrica por difração a laser.....................44

Tabela 13b - Parâmetros estatísticos da distribuição granulométrica (phi).................44 
Tabela 14 - Valores da análise química dos sedimentos de fundo da porção SW do Reservatório de Biritiba-Mirim (SP) em área protegida por mata

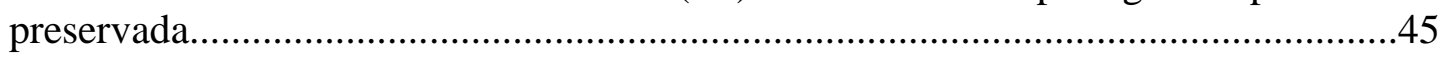

Tabela 15 - Valores da análise química dos sedimentos de fundo da porção SW do Reservatório de Biritiba-Mirim(SP) em área próxima ao reservatório com atividade agrícola.

Tabela 16 - Valores da análise química dos sedimentos de fundo da cabeceira do

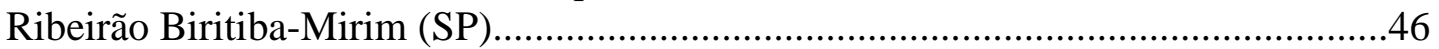

Tabela 17 - Valores da Classificação da qualidade de elementos em sedimentos......

Tabela 18. Valores dos parâmetros químicos da água analisados em laboratório para o Reservatório de Biritiba-Mirim (SP) nas áreas com mata preservada. Os valores apresentados são apenas os obtidos acima dos limites de detecção do aparelho

Tabela 19 - Valores dos parâmetros químicos da água analisados em laboratório para o Reservatório de Biritiba-Mirim (SP) em áreas sob influência de atividade agrícola. Os valores apresentados são apenas os obtidos acima dos limites de detecção do aparelho

Tabela 20 - Valores dos parâmetros químicos da água analisados em laboratório para o Reservatório de Biritiba-Mirim (SP) no ponto considerado de referência. Os valores apresentados são apenas os obtidos acima dos limites de detecção do aparelho

Tabela 21. Comparação entre os valores obtidos da análise química da água das amostras analisadas e coletadas no reservatório com os valores máximos dos parâmetros das normativas em questão. 51

Tabela 22. Tabela comparativa entre os valores em hectares de cada amostra, calculada em 1990 e em 2011 


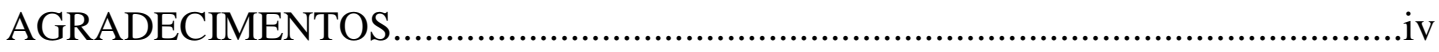

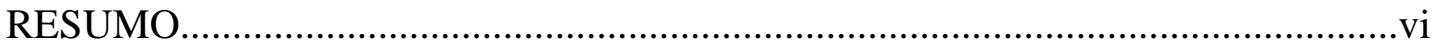

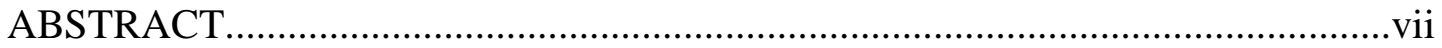

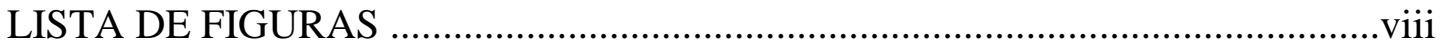

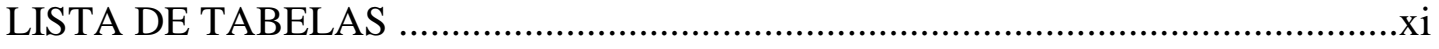

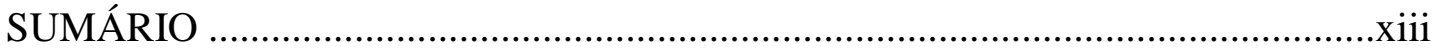

\section{INTRODUÇÃO}

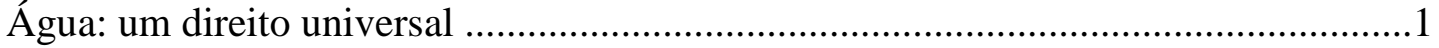

2. OBJETIVOS

\section{REVISÃO BIBLIOGRÁFICA}

3.1. Bacia Hidrográfica do Alto tietê 3

3.2. Legislação Hídrica Brasileira

3.2.1. Particularidades da Legislação Hídrica Federal .................................... 5

3.2.2. Particularidades da Legislação do Estado de São

Paulo

3.3. Índices da Qualidade da Água com base no CONAMA 357/2005 e Ministério da

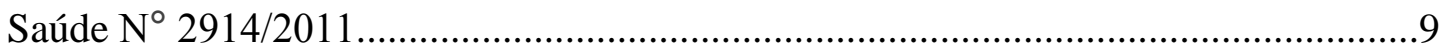

3.4. Importância da Qualidade dos Sedimentos de fundo..........................................12

3.5. Uso e Ocupação do Solo no Entorno dos Reservatórios.......................................16

3.6. Metodologia de Análise do Uso e Ocupação de um Território com Base em Sensoriamento Remoto.

3.6.1. Processamento digital de imagens orbitais........................................18

3.7. Caracterização do Reservatório de Biritiba-Mirim.............................................18

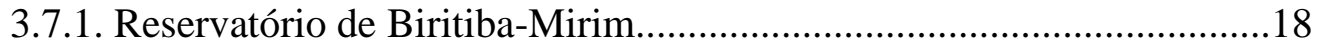

3.7.2. Localização do reservatório......................................... 19

3.7.3. Características climáticas..............................................................21

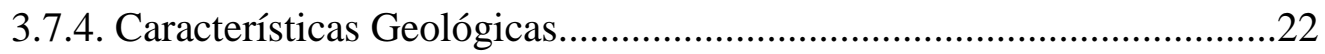

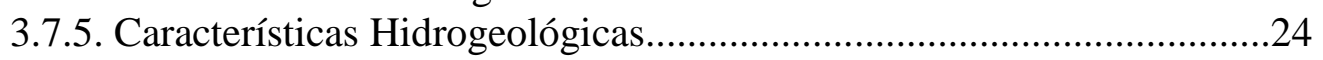

3.7.8. Características Pedológicas.............................................................26

3.7.7. Características Geomorfológicas.......................................................26

\section{MATERIAIS E MÉTODOS}

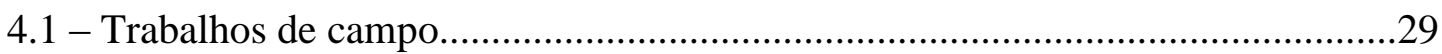

4.2- Medição de Parâmetros Físico-Químicos da água...........................................29

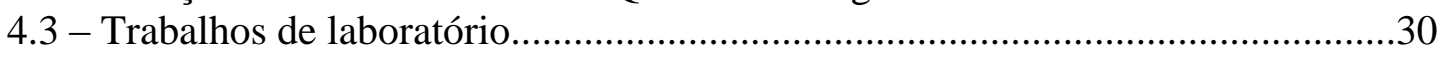

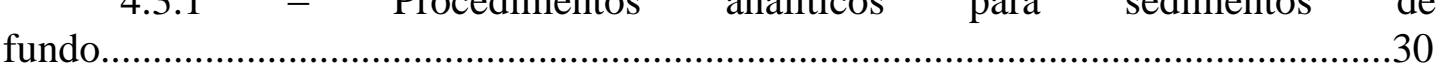


4.3.2 - Análise Química dos Sedimentos..........................................................31

4.3.3 - Análise Química da Água.................................................................32

4.4 - Análise do Uso e Ocupação do Solo por Sensoriamento Remoto........................33

\section{RESULTADOS}

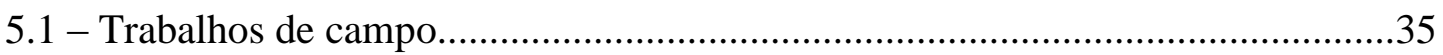

5.1.1. Localizações dos Pontos Coletados............................................................35

5.2- Medição de Parâmetros Físico-Químicos da Água..............................................39

5.3 - Resultados de Matéria Orgânica (MO), umidade e

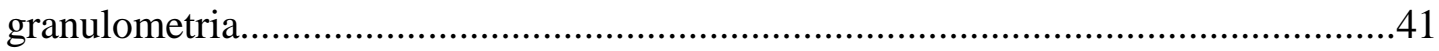

5.3.1 - Granulometria de Sedimentos de fundo.............................................41

5.3.2 - Análise Química dos Sedimentos de fundo........................................45

5.3.3 - Análise Química da Água.................................................................. 49

5.4 - Análise do Uso e Ocupação do Solo por Sensoriamento remoto........................53

\section{DISCUSSÃO}

6.1. Parâmetros Físico-Químicos da Água...............................................................57

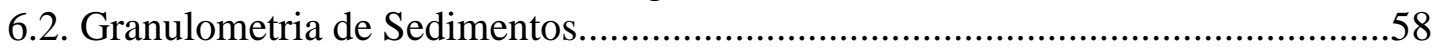

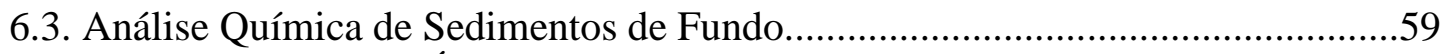

6.4. Análise Química da Água..................................................................................61

6.5. Análise do Uso e Ocupação do Solo por Sensoriamento Remoto.........................62

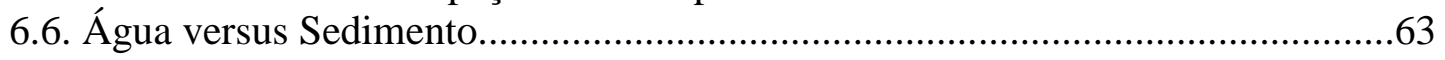

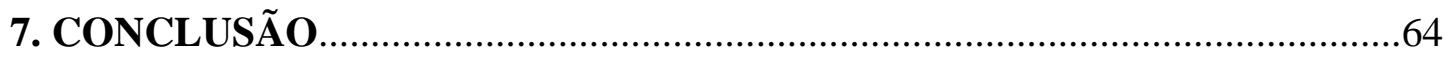

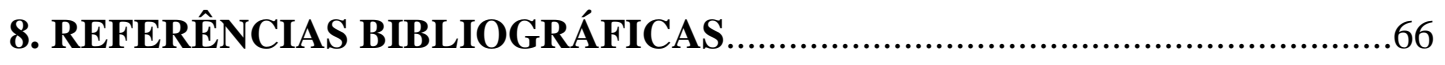




\section{INTRODUÇÃO}

\section{Água: Um Direito Universal}

A intensa urbanização pela qual passou todo o planeta, com grandes deslocamentos populacionais em direção às grandes metrópoles, e o aumento das atividades industriais potencializaram os problemas, entre eles, a ameaça pelo desabastecimento de água, consequência do balanço inadequado entre a disponibilidade de água potável e a demanda por esse recurso.

Esse é o caso da Região Metropolitana de São Paulo. As represas de água que abastecem os milhões de habitantes da região se encontraram em situação crítica no ano de 2014, devido à falta de chuvas, às decisões públicas inadequadas na gestão de recursos hídricos e ao uso excessivo de água pela população.

Atualmente existe uma preocupação global com a quantidade e a qualidade da água para consumo, pois com o crescimento populacional e econômico exagerado, há alteração do ciclo natural da água que se degrada e se torna imprópria para consumo e, em resposta a essas causas, há consequência para a saúde pública.

Dessa forma, a construção de sistemas como reservatórios em cascata, formados pela intercepção de rios através da construção de barragens são essenciais no que tange, principalmente, à captação de água para abastecimento urbano.

A inadequada gestão e planejamento do uso e ocupação do solo face ao crescimento populacional e ao desenvolvimento de atividades agrícolas no entorno de reservatórios, já que terrenos em suas proximidades apresentam condições adequadas à esta prática, vem colocando esses reservatórios em condições de atenção quanto à manutenção da qualidade de suas águas.

Neste contexto enquadra-se o reservatório de Biritiba-Mirim (SP), foco dessa dissertação, uma vez que os defensivos e fertilizantes agrícolas empregados em seu entorno podem estar contaminando o solo e migrando por escoamento superficial para a lâmina d'água, comprometendo a qualidade da água desse reservatório destinado ao abastecimento público. 


\section{OBJETIVO}

A presente dissertação tem como principal objetivo realizar um estudo comparativo da qualidade da água e de sedimentos de fundo entre a área protegida por mata nativa e uma área agrícola, ambas localizadas na porção SW do Reservatório de Biritiba-Mirim em SP.

O objetivo secundário diz respeito a uma avaliação do uso e ocupação do solo e da pressão antrópica e agrícola sobre a manutenção da qualidade da água desse reservatório. Nesse caso utilizou-se da ferramenta sensoriamento remoto para a comparação das imagens obtidas dos anos de 1990 e 2011 de modo comparativo quanto ao uso e ocupação do entorno do reservatório.

Paralelamente serão discutidos alguns aspectos referentes à qualidade da água e dos sedimentos de fundo, segundo os critérios da federação (CONAMA) e as do MINISTÉRIO DA SAÚDE. 


\section{REVISÃO BIBLIOGRÁFICA}

\subsection{Bacia Hidrográfica do Alto Tietê}

A região que comporta os reservatórios de Taiaçupeba, Jundiaí, BiritibaMirim, Ponte Nova, Paraitinga e Salesópolis é uma importante fonte estratégica como reserva de abastecimento para os municípios de Mogi das Cruzes, Suzano, BiritibaMirim e parte do Município de São Paulo.

Nesta região localiza-se a Bacia Hidrográfica do Alto Tietê que corresponde à área drenada pelo rio Tietê desde suas nascentes em Salesópolis, até a Barragem de Rasgão. Compreende uma área de $5.900 \mathrm{~km}^{2}$, com extensa superfície urbanizada e integrada por 35 municípios. Caracteriza-se por apresentar seus regimes hidráulico e hidrológico extremamente complexos, em virtude das profundas alterações introduzidas por obras hidráulicas e por efeitos antrópicos bastante diversos (SILVA, 2003).

Os principais contribuintes do rio Tietê nas suas cabeceiras são os rios Claro, Paraitinga, Jundiaí, Biritiba-Mirim e Taiaçupeba que, juntamente com o próprio rio Tietê, compõem o quadro dos mais importantes mananciais de abastecimento de água da região, destacando-se os reservatórios Ponte Nova, Jundiaí e Taiaçupeba, projetados e implantados para abastecimento público como finalidade principal e, secundariamente, para controle de enchentes (SILVA, 2003).

De acordo com o Departamento de Água e Energia Elétrica - DAEE, o reservatório de Taiaçupeba foi construído em 1976; o Jundiaí, em 1989; e o Ponte Nova em 1971. O reservatório de Biritiba-Mirim foi concluído no ano de 2001 e o Paraitinga no ano de 2003.

O reservatório de Biritiba-Mirim, a penúltima barragem implantada pelo DAEE na região das cabeceiras do rio Tietê, foi escolhido para o desenvolvimento dessa dissertação, por se tratar de um reservatório recentemente construído e possivelmente ainda não submetido a impacto ambiental mais severo. Segundo porque é contornado por diversas pequenas propriedades, as quais têm como foco principal a atividade hortifrutigranjeira e essa pode ser fator de comprometimento da qualidade da água, podendo produzir e dispersar poluentes provindos de fontes difusas, isto é, insumos agrícolas (fertilizantes, herbicidas, inseticidas, fungicidas, entre outros), bem como por se prestar a diversos usos, como o abastecimento urbano e industrial. 
O reservatório de Biritiba-Mirim encontra-se em meio a solos ricos em nutrientes e o seu entorno é utilizado para atividade agrícola, principalmente a horticultura na produção de flores ornamentais e cogumelos além de diversas variedades de hortaliças comestíveis. Este reservatório ocupa $11,4 \mathrm{Km}^{2}$, sendo drenada em uma área de $75 \mathrm{Km}^{2}$ e faz parte do Sistema Produtor Alto Tietê e forneceu água para 3,5 milhões de habitantes da Região Leste da Grande São Paulo (Figura 1).

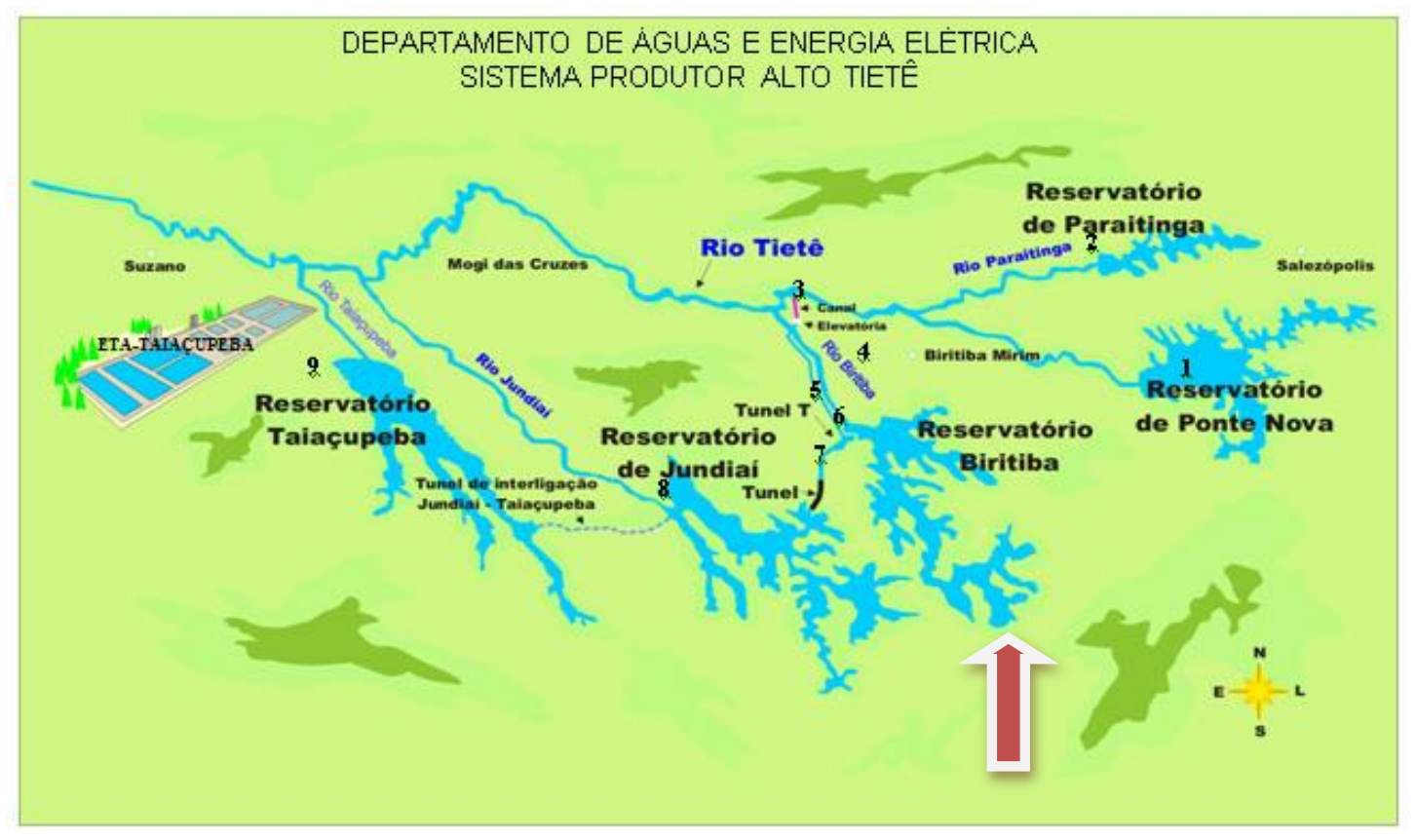

Figura 1 - Bacia hidrográfica do Alto Tietê e indicação (seta vermelha) do Reservatório estudado (Fonte: http://www.daee.sp.org.br)

De acordo com os dados do DAEE, as águas provenientes dos reservatórios Ponte Nova e Paraitinga são parcialmente derivadas até o túnel de interligação Tietê/Biritiba e através de sistemas canal-túnel-canal, é transferida para o reservatório Jundiaí e depois para o reservatório de Taiaçupeba, onde é feita a captação pela SABESP.

Este sistema em cascata, de Salesópolis até Taiaçupeba, está em funcionamento desde junho de 1999, e atualmente disponibiliza um total de água de $10 \mathrm{~m}^{3} / \mathrm{s}$, desde a entrada em funcionamento dos reservatórios Biritiba e Paraitinga. A meta é disponibilizar até 15 m³/s de água para a Região Metropolitana de São Paulo. 


\subsection{Legislação Hídrica Brasileira}

\subsubsection{Particularidades da Legislação Hídrica Federal}

Durante a Revolução Industrial, com o aumento populacional e a maior utilização de energia elétrica para o desenvolvimento do país, surge a necessidade do desenvolvimento de legislações e políticas com o intuito de valorizar os recursos hídricos do Brasil. Neste contexto, em 1934 foi criado o Decreto Federal 24.643, que aprovou o Código de Águas Brasileiro. Desta forma, abrem-se conceitos relativos ao uso e à propriedade da água, sendo estabelecida uma Política Nacional de Gestão de Águas.

A evolução dos problemas socioeconômicos do país possibilitou alterações de novas formas legais. Entre elas, a Constituição Federal de 1988 (BRASIL) que estabelece em seu artigo 225 que "todos tem direito ao meio ambiente ecologicamente equilibrado, bem de uso comum do povo e essencial à sadia qualidade de vida, impondo-se ao Poder Público e à coletividade o dever de defendêlo e preservá-lo para as presentes e futuras gerações".

No Brasil, a Lei Federal n 9.433/1997, que instituiu a Política Nacional de Recursos Hídricos e o Sistema Nacional de Gerenciamento de Recursos Hídricos, em seu Art. $2^{\circ}$ traz como um de seus objetivos assegurar à atual e às futuras gerações a necessária disponibilidade de água, em padrões de qualidade adequados aos respectivos usos. O Art. $9^{\circ}$ do enquadramento dos corpos d'água em classes, segundo os usos preponderantes da água, visa assegurar às águas qualidade compatível com os usos mais exigentes a que forem destinadas e diminuir os custos de combate à poluição das águas, mediante ações preventivas permanentes.

O Conselho Nacional do Meio Ambiente (CONAMA), com a revisão da CONAMA 20/1986, cria a Resolução No 357/2005, em seu Art. 4. dispõe sobre a classificação das águas doces, salobras e salinas do território nacional. Nessa resolução destaca-se interesse e preocupação com o abastecimento de água para o consumo humano e também com a irrigação de hortaliças que são consumidas cruas e de frutas que se desenvolveram rentes ao solo e que sejam ingeridas cruas.

Destaca-se também que o Art. 14. dessa mesma resolução trata do conjunto de parâmetros de qualidade da água selecionados de acordo com os instrumentos da 
Política Nacional de Recursos Hídricos, que deverá ser monitorada pelo poder público e convênios firmados com laboratórios, universidades e órgãos afins.

\subsubsection{Particularidades da Legislação do Estado de São Paulo}

Na Constituição do Estado de São Paulo de 2008, o artigo 205 retrata que - O Estado instituirá, por lei, o sistema integrado de gerenciamento dos recursos hídricos, congregando órgãos estaduais e municipais e a sociedade civil, e assegurará meios financeiros e institucionais para:

I - o uso racional das águas superficiais e subterrâneas e assegura como prioridade o abastecimento de água às populações;

II e III - seu aproveitamento múltiplo e sua proteção contra ações que possam comprometer seu uso atual ou futuro;

IV - a defesa contra eventos críticos, que ofereçam riscos à saúde e segurança públicas e prejuízos econômicos ou sociais.

A Lei Estadual № 1.172 delimita as áreas de proteção relativas aos mananciais, cursos e reservatórios de água, a que se refere o Artigo $2 .^{\circ}$ da Lei Estadual $\mathrm{n}^{\circ} .898$, de 18 de dezembro de 1975, estabelece normas de restrição de uso do solo em tais áreas e dá providências correlatas.

No artigo $1 .^{\circ}$ - Ficam delimitadas, como áreas de proteção, as contidas entre os divisores de água do escoamento superficial contribuinte dos mananciais, cursos e reservatórios de água. $\mathrm{O}$ artigo $2 .^{\circ}$ - Nas delimitações de que trata o artigo anterior, constituem áreas ou faixas de $1 .^{a}$ categoria ou de maior restrição:

I - os corpos de água;

II - a faixa de 50 metros de largura, medida em projeção horizontal, a partir da linha de contorno correspondente ao nível de água máximo dos reservatórios públicos, existentes e projetados;

III - a faixa de 20 metros de largura, medida em projeção horizontal, a partir dos limites do álveo, em cada uma das margens dos rios e das de seus afluentes primários, bem como em cada uma das margens dos afluentes primários dos reservatórios públicos, existentes e projetados;

IV - as faixas definidas no Artigo 2. ${ }^{\circ}$ e sua alínea "a" da Lei Federal No. 4.771/1965, referentes às margens dos demais cursos de água; 
V - as áreas cobertas por mata e todas as formas de vegetação primitiva;

VI - as áreas com quota inferior a 1,50 metros, medida a partir do nível máximo dos reservatórios públicos existentes e projetados, e situados a uma distância mínima inferior a 100 metros das faixas de que trata os incisos II e III deste artigo;

VII - as áreas onde a declividade média for superior a $60 \%$, calculada a intervalos de 100 metros a partir do nível de água máximo dos reservatórios públicos existentes e projetados e dos limites do álveo dos rios, sobre as linhas de maior declive.

O Ministério da Saúde, no dia 12 de dezembro de 2011 estabeleceu a portaria número 2914, que revogou integralmente a Portaria MS no 518, de 25/03/2004, que dispõe sobre os procedimentos e responsabilidades relacionados ao controle e cuidados da qualidade da água para consumi humano e seu padrão de potabilidade em todo o território nacional. Desse modo, a água potável deve estar em conformidade com os valores de referência máximos e mínimos estabelecidos por essa portaria, como: padrão de turbidez para água pós-filtração ou pré-desinfecção, padrão microbiológico de potabilidade da água para consumo humano; padrão de potabilidade para substâncias químicas que representam risco à saúde; padrão de radioatividade para água potável; padrão de aceitação para consumo humano.

Desde 1974 a CETESB, Companhia de Tecnologia de Saneamento Ambiental, no Estado de São Paulo, tem como objetivo manter o equilíbrio, a manutenção e os seus múltiplos usos, sendo a responsável pela fiscalização e monitoramento da qualidade das águas e a operação da Rede de Monitoramento da Qualidade das Águas Interiores (rios e reservatórios), situados nas 22 Unidades de Gerenciamento de Recursos Hídricos (UGRHIs), de acordo com a Lei Estadual $\mathrm{n}^{\circ}$ 9.034 de 27 de dezembro de 1994.

Em 21 de dezembro de 2014 a CETESB passou a utilizar a Portaria 045/2014 do Ministério da Saúde, que revisou os valores orientadores (VO) para Solo e Água Subterrânea no Estado de São Paulo de 2005, que passaram a ser aplicados como referência para proteção da qualidade do solo e gerenciamento de áreas contaminadas no Estado de São Paulo. 
Tabela 1 -Valores máximos dos parâmetros químicos da água para consumo humano, somente com os elementos químicos analisados nessa dissertação. Os espaços expressos através de (-) mostram que o parâmetro analisado não trata dos elementos em estudo

\begin{tabular}{|c|c|c|c|c|}
\hline $\begin{array}{c}\text { PARÂMETROS } \\
\text { INORGÂNICOS }\end{array}$ & $\begin{array}{c}\text { CONAMA } \\
\text { 357/2005 } \\
\text { CLASSE I }\end{array}$ & $\begin{array}{c}\text { CONAMA } \\
\text { 357/2005 } \\
\text { CLASSE II }\end{array}$ & $\begin{array}{c}\text { MS No } 2914 \\
(\mathbf{2 0 1 1})\end{array}$ & $\begin{array}{c}\mathbf{M S ~ N}^{\circ} \text {. 045 } \\
(\mathbf{2 0 1 4})\end{array}$ \\
\hline $\begin{array}{c}\text { ALUMÍNIO } \\
\text { DISSOLVIDO } \\
(\mathrm{Al})\end{array}$ & $0,1 \mathrm{mg} / \mathrm{L}$ & $0,2 \mathrm{mg} / \mathrm{L}$ & $0,2 \mathrm{mg} / \mathrm{L}$ & $(-)$ \\
\hline CÁLCIO (Ca) & $(-)$ & $(-)$ & $(-)$ & $(-)$ \\
\hline FERRO (Fe) & $0,3 \mathrm{mg} / \mathrm{L}$ & $5,0 \mathrm{mg} / \mathrm{L}$ & $0,3 \mathrm{mg} / \mathrm{L}$ & $(-)$ \\
\hline FÓSFORO (P) & $0,1 \mathrm{mg} / \mathrm{L}$ & $0,15 \mathrm{mg} / \mathrm{L}$ & $(-)$ & $(-)$ \\
\hline $\begin{array}{c}\text { MANGANÊS } \\
(M n)\end{array}$ & $0,1 \mathrm{mg} / \mathrm{L}$ & $0,5 \mathrm{mg} / \mathrm{L}$ & $0,1 \mathrm{mg} / \mathrm{L}$ & $(-)$ \\
\hline $\begin{array}{c}\text { MAGNÉSIO } \\
(M g)\end{array}$ & $(-)$ & $(-)$ & $(-)$ & $(-)$ \\
\hline $\begin{array}{c}\text { SÓDIO (Na) } \\
\text { ZINCO (Zn) }\end{array}$ & $0,18 \mathrm{mg} / \mathrm{L}$ & $5 \mathrm{mg} / \mathrm{L}$ & $5 \mathrm{mg} / \mathrm{L}$ & $1,8 \mathrm{mg} / \mathrm{L}$ \\
\hline
\end{tabular}

Fonte: CONAMA 357/2005, Ministério da Saúde N²914/2011 e Nº 045/2014

A Tabela 1 exibe os valores máximos dos parâmetros inorgânicos estudados na área de desenvolvimento dessa dissertação, comparando os padrões de potabilidade da água segundo a Resolução CONAMA 357/2005, a PORTARIA No 2914/2011 do Ministério da Saúde (MS) e, por fim, o padrão utilizado pela CETESB segundo a PORTARIA 045/2014 do MS, sendo os elementos químicos inseridos nessa tabela somente os analisados no laboratório de análise química da SABESP em Botucatu (SP).

Atualmente, a classificação das águas que melhor se enquadra é a de Classe 1, de acordo com a Resolução CONAMA 357/2005, pois há necessidade de tratamento simplificado da água antes de disponibilizá-la à população da grande São Paulo.

A Portaria MS N518/2004 do Ministério da Saúde revogada pela Portaria do MS N 2914 (2011), determina os padrões de potabilidade da água destinada ao uso para consumo humano, sendo de caráter obrigatório em todo o território nacional. Define que a água potável deve atender aos parâmetros físicos, químicos e biológicos de qualidade determinando cada parâmetro, mais restritivos para consumo humano que os determinados pela resolução CONAMA N 357/2005 para águas superficiais (PEREIRA, 2008). A portaria No. 045/2014 do MS dispõe sobre a aprovação dos 
valores orientadores para Solos e águas subterrâneas no Estado de São Paulo - 2014, em substituição aos valores orientadores de 2005.

\section{3. Índices da Qualidade da Água com base no CONAMA 357/2005 e Ministério da Saúde $N^{\circ}$ 2914/2011.}

A qualidade da água pode ser traduzida por meio de vários parâmetros relacionados às suas características físicas, químicas e biológicas. Os limites de precisão dos equipamentos utilizados para a análise estão vinculados aos valores utilizados pela SABESP, uma vez que a calibração dos mesmos é realizada pelo próprio órgão, assim a sonda empregada, gentilmente cedida pela SABESP veio calibrada usando esses critérios. É importante ressaltar que a CETESB e a SABESP nada mencionam a respeito dos parâmetros físico-químicos da água. Os parâmetros propostos visam verificar as fontes pontuais e fontes difusas de poluição, sendo somente os parâmetros avaliados nessa dissertação descritos resumidamente a seguir:

\section{TURBIDEZ (NTUs)}

A turbidez da água é dada pela quantidade de partículas em suspensão, que podem ou não causar turbidez e aparência turva. Ela pode ser medida pela capacidade de um feixe de luz atravessar a água. Desta forma, pode-se dizer que as partículas em suspensão, que causam a turbidez, contribuem para a poluição, pois dificulta a penetração de raios solares e restringe a ação de seres fotossintetizantes, que reduzem a reposição de oxigênio (VON SPERLING, 2005). Vale lembrar, que o limite de turbidez estabelecido pela Resolução CONAMA 357/2005 para águas de Classe II é de até 100 NTUs (Número de unidades de transferência) e de até 40 NTUs para águas de classe III.

\section{TEMPERATURA $\left({ }^{\circ} \mathrm{C}\right)$}

Segundo Von Sperling (2005) a temperatura mede a intensidade de calor. Suas elevações diminuem a solubilidade dos gases e aumentam sua taxa de transferência e a taxa de reações físicas, químicas e biológicas. Para o autor, a temperatura deve ser analisada em conjunto com outros parâmetros, como por exemplo, o oxigênio 
dissolvido. Prado (2004) menciona que, em reservatórios ocorre estratificação térmica, caracterizada pela diferença de temperatura nas camadas, promovendo a propagação do calor. Isto se deve pelo transporte de massa d'água pelo vento que promove a turbulência da água. Segundo a CETESB 2014, nas nossas águas superficiais a temperatura pode variar de 4 a $30^{\circ} \mathrm{C}$ sendo flutuações sazonais em conformidade com o clima vigente.

\section{OXIGÊNIO DISSOLVIDO (mg/L)}

O oxigênio dissolvido (OD) é vital para os seres vivos aeróbios e, em sua ausência, o meio torna-se anaeróbio e muitas vezes com maus odores. Este é o principal parâmetro de caracterização dos efeitos da poluição das águas por despejos orgânicos (VON SPERLING, 2005). Para Prado (2004) quanto mais reduzida a concentração de oxigênio, mais poluído está o curso d'água. A quantidade de oxigênio é proporcional à temperatura da água e pode ser expressa quando há utilização do gás na oxidação biológica da matéria orgânica recebida pelo ambiente aquático. Segundo a Resolução CONAMA 357/2005, o OD, em qualquer amostra, não pode ser inferior a $6 \mathrm{mg} / \mathrm{L}$ para águas de classe $\mathrm{I}$ e de $5 \mathrm{mg} / \mathrm{L}$ para águas de classe II

\section{CONDUTIVIDADE ELÉTRICA $(\mu \mathrm{m} / \mathrm{s})$}

A capacidade do meio de conduzir eletricidade denomina-se condutividade elétrica, sendo esta função, no meio aquático, dependente de outros fatores, como valores médios de $\mathrm{pH}$, temperatura e a composição iônica por macro nutrientes $(\mathrm{Ca}$, $\mathrm{Mg}, \mathrm{K}, \mathrm{Na}, \mathrm{SO} 4, \mathrm{Cl})$. A atividade iônica aumenta $2 \%$ para cada grau centígrado. Para valores de $\mathrm{pH}$ extremos, menores do que 5 e maiores do que 9, poucos íons interferem na condutividade, entre eles, $\mathrm{H}+\mathrm{e} \mathrm{OH}-$. Alguns processos importantes dos ecossistemas aquáticos, como por exemplo, a decomposição da matéria orgânica e a fotossíntese influenciam diretamente na variável da condutividade elétrica, uma vez que se associam à composição iônica da água (PRADO, 2004). Em geral, níveis superiores a 100/cm sugerem ambientes impactados (CETESB 2014). 


\section{POTENCIAL HIDROGENIÔNICO $(\mathrm{pH})$}

Segundo Prado (2004) o pH é uma das variáveis mais importantes no meio aquático, ao mesmo tempo em que é uma das mais difíceis de serem interpretadas. Ele representa a concentração de íons hidrogênio H+ e indica a acidez, neutralidade ou alcalinidade da água. Meios que se apresentam ácidos, ou seja, com valores baixos de $\mathrm{pH}$, mostram elevadas concentrações de ácidos orgânicos e/ou inorgânicos ou ainda de ambos. Dos processos importantes que ocorrem no meio aquático, os que mais interferem no pH do meio são a fotossíntese, a respiração e a assimilação de nitrogênio pelo fitoplâncton. Von Sperling (2005) destaca que o pH se altera quando há despejo de matéria orgânica no corpo d'água e, consequentemente, há o processo de oxidação. Para o autor, o pH não tem implicação na saúde humana, a menos que os valores sejam extremamente baixos ou elevados. Os critérios de proteção à vida aquática fixam o pH entre 6 e 9. Para o Ministério da Saúde o intervalo de pH para águas de abastecimento é estabelecido pela Portaria MS no 2914/2011 entre 6,0 e 9,5, parâmetro que objetiva minimizar também os problemas de incrustação e corrosão das redes de distribuição.

\section{$\underline{\text { POTENCIAL DE OXIRREDUÇ̃̃O (PO) }}$}

O potencial de oxido-redução é uma medida da tendência de uma espécie química em ganhar elétrons do meio. Para Teixeira et al (1999) o ORP é controlado por diversos fatores presentes no meio aquático, como por exemplo, o tipo de sedimento, águas superficiais e/ou águas subterrâneas. ORP juntamente com o pH controlam as reações da maioria dos compostos orgânicos e inorgânicos, que variam de acordo com a profundidade e as espécies químicas. O entendimento da distribuição dos processos de oxidação-redução é fundamental para prever o destino e o transporte dos contaminantes químicos em sistemas de águas subterrâneas.

Em 13 de agosto de 1998, foi criado o Índice de Qualidade de Águas Brutas para fins de Abastecimento Público (IAP) e o Índice de Preservação da Vida Aquática (IVA) através da Resolução da Secretária do Meio Ambiente do Estado de São Paulo, SMA-65. Depois disso, a CETESB integrou diversos parâmetros físicoquímicos da água em um único indicador (CETESB, 2009), segundo tabela 2. 
Tabela 2 - Índices de qualidade da água e respectivas variáveis que os integram

\begin{tabular}{|c|c|}
\hline Índice de Qualidade & Variáveis de Qualidade \\
\hline $\begin{array}{c}\text { IQA } \\
\text { (Índice de Qualidade das Águas) }\end{array}$ & $\begin{array}{l}\text { Temperatura, } \mathrm{pH} \text {, oxigênio dissolvido, } \\
\text { demanda bioquímica de oxigênio, coliformes } \\
\text { termo tolerantes, nitrogênio total, fósforo } \\
\text { total, resíduos totais e turbidez. }\end{array}$ \\
\hline $\begin{array}{c}\text { IAP } \\
\text { (Índice de Qualidade das Águas para fins de } \\
\text { abastecimento público) }\end{array}$ & $\begin{array}{l}\text { Temperatura, } \mathrm{pH} \text {, oxigênio dissolvido, } \\
\text { demanda bioquímica de oxigênio, coliformes } \\
\text { termo tolerantes, nitrogênio total, fósforo } \\
\text { total, resíduos totais e turbidez, ferro } \\
\text { dissolvido, manganês, alumínio dissolvido, } \\
\text { cobre dissolvido, zinco, potencial de } \\
\text { formação de trihalometanos, número de } \\
\text { células de cianobactérias, cádmio, chumbo, } \\
\text { cromo total, mercúrio e níquel. }\end{array}$ \\
\hline $\begin{array}{c}\text { IVA } \\
\text { (Índice de qualidade das águas para proteção } \\
\text { da vida aquática. Esse índice é completado } \\
\text { pelos índices de Comunidades Aquáticas) }\end{array}$ & $\begin{array}{l}\text { Oxigênio dissolvido, pH, toxicidade, cobre, } \\
\text { zinco, chumbo, cromo, mercúrio, níquel, } \\
\text { cádmio, surfactantes, fenóis, clorofila e } \\
\text { fósforo total. }\end{array}$ \\
\hline $\begin{array}{c}\text { CQS } \\
\text { (Critério de Avaliação da Qualidade dos } \\
\text { Sedimentos) }\end{array}$ & $\begin{array}{l}\text { Leva em consideração a classificação dos } \\
\text { sedimentos em diferentes linhas de } \\
\text { evidência: concentração de substâncias } \\
\text { químicas, ecotoxidade, mutagenicidade e } \\
\text { comunidade bentônica. }\end{array}$ \\
\hline
\end{tabular}

Fonte: Cetesb, 2009

\subsection{Importância da Qualidade dos Sedimentos de Fundo}

Os sedimentos lacustres (corrente, fundo e suspensão) são formados por partículas de diversos tamanhos, formas e composição química. Essas partículas podem ser transportadas a partir inicialmente dos processos de intemperismo dos materiais rochosos e sua posterior erosão, podendo ser distribuídos ao longo dos vales e planícies de inundação do sistema fluvial e posteriormente depositados no ambiente lacustre. 
A classificação quanto ao tamanho de partícula nos sedimentos esta dividido nas seguintes categorias: argila $(<4 \mu \mathrm{m})$, silte $(4-62 \mu \mathrm{m})$, areia $(62-2000 \mu \mathrm{m}) \mathrm{e}$ cascalho (>2000 $\mu \mathrm{m})$.

Segundo Jesus et al (2004) a liberação antrópica de metais pesados nos diversos ambientes naturais tem causado grandes impactos ambientais. Observa-se que os ambientes aquáticos, por estarem em local estratégico quanto à interação com a população, sofrem consequências negativas em seu meio. $\mathrm{O}$ autor relata que tanto a água, como materiais particulados, sedimentos e organismos aquáticos são preferidos como base de referência quanto a quantificação da qualidade de águas em avaliações ambientais devido às facilidades de coleta, estocagem e tratamento das amostras e às maiores concentrações encontradas de poluentes e/ou contaminantes.

Para Hortellani et al (2008) a poluição dos sedimentos de fundo está estreitamente ligada à poluição das águas e tem origem em diversas fontes, como: efluentes domésticos e industriais, carga urbana e agrícola. Núñez et al (2006) relata que o uso de agroquímicos para aumentar o suprimento de nutrientes e a correção do pH do solo podem causar degradação química do solo devido ao acúmulo em níveis indesejáveis.

Os sedimentos de fundo são considerados bons indicadores de espécies poluentes uma vez que apresentam alta capacidade de sorção, na qual as concentrações de poluentes tornam as ordens de grandeza maiores do que as águas correspondentes. Eles ainda possibilitam o conhecimento das principais fontes de poluição dentro de um sistema aquático (JESUS et al 2004). Para Hortellani opus cit. os sedimentos tem esta utilização por possuírem grande capacidade de incorporação e acumulação de elementos contaminantes. Por serem carreados devido ao processo de erosão do solo e através de cursos d'água, torna-se possível rastrear as fontes de contaminação por meio de coletas e análise destes sedimentos em diferentes pontos.

Os diversos processos bióticos e abióticos podem remobilizar as espécies poluentes passando a constituir fonte de poluição secundária, capaz de afetar a qualidade da água. Deste modo, nota-se que a contaminação de sedimentos é um importante problema ambiental (JESUS et al, 2004).

Hortellani et al (2008) opus cit menciona que as condições abióticas do meio aquático ( $\mathrm{pH}$, salinidade, entre outras) interferem na liberação de poluentes incorporados ao sedimento. Com isso, as mudanças das condições ambientais podem 
transformar os sedimentos em fontes de contaminação da água e dos organismos bentônicos.

E para avaliar o grau de contaminação química do sedimento, visando à proteção da vida aquática, CETESB (2005) utiliza os valores orientadores estabelecidos pela resolução CONAMA n ${ }^{0}$ 545/2012, que revogou a Resolução 344/2004; para disposição do material dragado em águas brasileiras, especificando valores limites de contaminantes químicos, baseados nos valores estabelecidos pelo Canadian Council of Ministers of the Environment (CCME). Estão divididos e classificados em cinco classes de qualidade, pois os valores de concentração para os elementos são muito distantes e não contemplam os que estão presentes pela classificação de TEL (Threshold Effect Level) e PEL (Probable Effect Level) resultando assim, em dados mais confiáveis.

A qualidade ÓTIMA, para cada contaminante, corresponde à concentração inferior a TEL. A qualidade BOA, a faixa entre TEL, inclusive, e a concentração correspondente a 50\% da distância entre TEL e PEL, somado a TEL. A qualidade REGULAR, a faixa superior a 50\% da distância entre TEL e PEL, somado a TEL e inferior a PEL. A qualidade RUIM, corresponde a faixa entre PEL, inclusive, e a concentração correspondente a 1,5 x de seu próprio valor. E a qualidade PÉSSIMA acima de 1,5 x PEL. A pior situação aparece quando as concentrações encontradas superam significativamente o valor de PEL (em mais de 50\%). Esta classificação é adotada atualmente pela CETESB (2005) e CETESB (2014) na avaliação dos sedimentos do Estado de São Paulo (Tabela 3).

De acordo com CETESB (2005) e CETESB (2014), a adoção desses valores deve ter caráter apenas orientador na busca de evidencias de contaminantes em concentrações capazes de causar efeitos deletérios, sobretudo com relação à toxicidade para a biota. A Resolução CONAMA 344/2004 instrui que as substâncias não presentes na Tabela 3 terão seus valores previamente estabelecidos pelo órgão ambiental competente. Existindo dados sobrevalores basais (valores naturais reconhecidos pelo órgão ambiental competente) de uma determinada região, estes deverão prevalecer sobre os valores, sempre que se apresentem mais elevados. 
Tabela 3 - Classificação da quantidade relativa em de elementos analisados nessa dissertação em sedimentos a partir de TEL e PEL.

\begin{tabular}{|c|c|c|c|c|c|}
\hline $\begin{array}{c}\text { PARÂMETROS } \\
(\mathbf{m g} / \mathbf{K g})\end{array}$ & ÓTIMA & BOA & REGULAR & RUIM & PÉSSIMA \\
\hline $\mathrm{As}$ & $<5,90$ & $\geq 5,9-11,5$ & $>11,5-<17,0$ & $17,0-25,5$ & $>25,5$ \\
\hline $\mathrm{Cd}$ & $<0,60$ & $\geq 0,6-2,1$ & $>2,1-<3,5$ & $3,5-5,3$ & $>5,3$ \\
\hline $\mathrm{Pb}$ & $<35,00$ & $\geq 35,0-63,2$ & $>63,2-<91,3$ & $91,3-137,0$ & $>137,0$ \\
\hline $\mathrm{Cu}$ & $<35,70$ & $\geq 35,7-$ & $>116,4-<197,0$ & $197,0-$ & $>295,5$ \\
& & 116,4 & & 295,5 & \\
\hline $\mathrm{Cr}$ & $<37,30$ & $\geq 37,3-63,7$ & $>63,7-<90,0$ & $90,0-135,0$ & $>135,0$ \\
\hline $\mathrm{Hg}$ & $<0,17$ & $\geq 0,170-$ & $>0,328-<0,486$ & $0,486-$ & $>0,729$ \\
& & 0,328 & & 0,729 & \\
\hline $\mathrm{Ni}$ & $<18$ & $\geq 18-27$ & $>27-<36$ & $36-54$ & $>54$ \\
\hline $\mathrm{Zn}$ & $<12$ & $\geq 123-219$ & $>219-<315$ & $315-473$ & $>473$ \\
\hline
\end{tabular}

Fonte: CETESB, 2011.

Nos sistemas lacustres, por exemplo, os reservatórios são considerados fontes potenciais de metais pesados, por representarem bacia de sedimentação com características específicas de ambientes deposicionais, podendo atingir níveis de contaminação bastante elevados em certos locais (ESTEVES, 1998).

Para Núñez et al (2006) os metais pesados presentes no solo erodido quando atingem cursos d'água contaminam-no, pois podem ser liberados quando há mudanças físico-químicas do meio e tornam-se perigosos em condições redutoras, desde que suas concentrações ultrapassem determinados limites especificados pelos órgãos de proteção ambiental. Entretanto, a solubilidade dos metais pesados quando depositados na superfície do solo depende da facilidade de remobilização dos mesmos.

Por outro lado, os metais de origem antrópica provêm de efluentes industriais, resíduos sólidos acondicionados de maneira inadequada, esgotos domésticos, emissões de poluentes atmosféricos, água de irrigação contaminada, queima de biomassa e principalmente de fertilizantes e defensivos agrícolas. Estes depois de lançados nas águas superficiais juntam-se aos materiais particulados ou são carregados e dissolvidos ou permanecem na forma coloidal. 


\subsection{Uso e Ocupação do Solo no Entorno dos Reservatórios}

Com o passar dos anos os reservatórios de captação de água passaram a apresentar significativas funções e por isso tornaram-se estratégicos para o desenvolvimento de atividades econômicas, como a agricultura, que cultiva diferentes tipos de plantios. No entanto, muitos desses plantios requerem o uso de agrotóxicos e implementos agrícolas que, por vezes, são com certa frequência usados sem nenhum critério em relação ao ambiente, em especial tornando-se um gerador de poluição para as águas do reservatório. Segundo Silva e Porto (2003) a transformação dos ambientes naturais em áreas de cultivo é considerada uma das maiores intervenções do homem no meio ambiente.

Tanto o melhoramento das condições de circulação através de rodovias antes e após a construção do reservatório e, principalmente, o acesso hídrico, promovem a crescente modernização agrícola do seu entorno. Esta atualização da agricultura está vinculada à intensificação do uso da terra no entorno do reservatório, a aplicação de defensivos agrícolas e o incremento de maquinários (PRADO, 2004).

Morais et al (2011) argumentam que a agricultura é uma atividade que requer espaço físico para que possa se desenvolver mas, para que haja uma área de tamanho adequado para esta prática, são executadas atividades antrópicas, como por exemplo, o desmatamento e as queimadas que acarretam consequências negativas ao meio ambiente, pois podem promover processos de erosão intenso, assoreamento dos mananciais e degradação dos recursos hídricos a ela associados. Quando estas atividades ocorrem próximas aos reservatórios, retira-se a vegetação protetora das margens, podendo permitir o despejo de agrotóxicos nos ambientes aquáticos, ameaçando os recursos hídricos.

De acordo com Prado (2004) estes poluentes também sofrem a interferência de fatores naturais (geologia, geomorfologia, declividade, pedologia, formato e densidade da bacia de drenagem, regime de chuvas, permeabilidade do solo e outros). Para Carvalho et al (2000) o desmatamento faz com que o solo fique exposto à lixiviação superficial e profunda, resultando no empobrecimento do solo e na condução do material para áreas mais baixas, entre elas rios e lagos.

Verifica-se que quando a água é utilizada na agricultura, no processo de irrigação, chega aos corpos d'água associada a alguns fertilizantes químicos, inseticidas, fungicidas e herbicidas, apresentando altos teores de sais e nutrientes 
(Morais et al 2011).

Casagrande e Salvador (2007) in Pereira (2008) afirmam que o uso intensivo e prolongado de fertilizantes e agrotóxicos e as maquinarias utilizadas no manejo do solo, somados à irrigação excessiva apresentam-se como potenciais poluidores, uma vez que contribuem com o arraste e infiltração de nutrientes (especialmente nitratos), sais e traços de compostos orgânicos.

O principal meio pelo qual os poluentes atingem um curso d'água, de maneira difusa, é o escoamento superficial. No entanto, identificar e quantificar esses poluentes não é tarefa fácil, pois para tal, faz-se necessário o conhecimento do comportamento destas substâncias no meio ambiente (meia-vida, percolação, persistência, degradação, deslocamento, dentre outros) e dos fatores naturais e antrópicos mencionados que interferem no transporte e disposição desses poluentes na água (PRADO, 2004).

\subsection{Metodologia de Análise do Uso e Ocupação de um Território com Base em Sensoriamento Remoto}

Segundo Moraes (2002) o sensoriamento remoto permite a detecção, aquisição e análise de informações da energia eletromagnética emitida ou refletida pelos objetos terrestres e registradas por sensores remotos. Estas informações passam a ser a base de dados para o processo de sua identificação. Por isso, os sensores remotos são muito importantes para a realização de mapeamento e de monitoramento de recursos naturais.

Para Novo (1992) in Prado (2004) os sensores remotos são capazes de coletar energia eletromagnética refletida e emitida pelos objetos terrestres e traduzi-la em sinal passível de ser registrado e apresentá-lo em forma adequada à extração de informações. $\mathrm{O}$ autor relata que esta tecnologia permite a obtenção de uma grande quantidade de informações a respeito de uma área ou ecossistema, apresentando baixo custo, boa qualidade e permitindo a visualização integrada do ambiente.

Os sistemas sensores também podem ser classificados como ativos e passivos. Os sensores passivos não possuem fonte própria de energia eletromagnética, como por exemplo, os sensores do satélite LANDSAT 5, os radiômetros e espectro radiômetros.

Uma vantagem importante é que as imagens do satélite LANDSAT 5 tem o mesmo período de repetitividade, de 16 dias e carrega o sensor de segunda geração 
denominado "Thematic Mapper" (TM), que distingue até 256 tons distintos de sinais, representando-os em 256 níveis de cinza, o que lhe confere grande capacidade de detectar e registrar diferenças na energia refletida pelos elementos que compõem a cena (MORAES, 2002). O satélite LANDSAT 5 opera em sete bandas espectrais e nessa dissertação utilizou-se cinco destas sete bandas espectrais, conforme demonstrado na Tabela 4.

Tabela 4. Bandas espectrais do TM/LANDSAT 5 com suas aplicações, utilizadas na dissertação

\begin{tabular}{|c|c|c|}
\hline Bandas & Espectro & Aplicação \\
\hline 1 & Azul & Estudos de sedimentos \\
\hline 2 & Verde & Mapeamento de vegetação \\
\hline 3 & Vermelho & Diferenciação de espécies vegetais \\
\hline 4 & Infravermelho & Delineamento de corpos d'água \\
\hline 5 & Infravermelho & Uso do solo \\
\hline
\end{tabular}

Fonte: MORAES, 2002

\subsubsection{Processamento digital de imagens orbitais}

O processamento digital de imagens se dá por meio de técnicas de análise de dados adquiridos pelos sensores remotos. Segundo Mascarenhas e Velasco (1984) in Prado (2004) a análise e a manipulação dos dados através de softwares é chamado processamento digital de imagens que pode ser dividido em três etapas: préprocessamento, classificação e pós-classificação. No pré-processamento os dados de satélite são preparados para se realizar a classificação da imagem, na qual há extração de informações das imagens para o reconhecimento de padrões homogêneos, afim de mapear áreas da superfície terrestre que correspondam aos temas de interesse. Na pós-classificação, que é utilizada após a classificação da imagem, o objetivo é uniformizar os temas e gerar uma imagem classificada com aparência mais homogênea. Nessa dissertação foram realizadas as etapas de préprocessamento e classificação das imagens.

\subsection{Caracterização do Reservatório de Biritiba-Mirim:}

\subsubsection{Reservatório de Biritiba-Mirim}

A área escolhida para o desenvolvimento dessa dissertação tem como base uma região com intensa atividade hortifrutigranjeira onde se destaca o cultivo de alface, couve, cogumelos, flores ornamentais, além da atividade de avicultura 
(grajais). Desta forma, a atividade agrícola e o uso de defensivos agrícolas na área tem sido um fator preocupante em áreas no entorno do reservatório, pois podem contaminar o solo e a água do reservatório que é utilizada para o abastecimento público.

A tabela 5 mostra as características do reservatório de Biritiba-Mirim.

Tabela 5. Características do reservatório de Biritiba-Mirim

\begin{tabular}{|c|c|}
\hline Características gerais do reservatóri & a-Mirim \\
\hline CARACTERÍSTICAS & DADOS \\
\hline Área & $11,4 \mathrm{~km}^{2}$ \\
\hline Área da bacia de drenagem & $75 \mathrm{~km}^{2}$ \\
\hline Formato & subdendrítico \\
\hline Volume acumulado & 60,2 milhões de $\mathrm{m}^{3}$ \\
\hline Volume operacional & 35 milhões de $\mathbf{m}^{3}$ \\
\hline Tempo de detenção & 0,95 ano \\
\hline Vazão regularizada & $1,75 \mathrm{~m}^{3} / \mathrm{s}$ \\
\hline Vazão máxima vertida para juzante & $30,50 \mathrm{~m}^{3} / \mathrm{s}$ \\
\hline Cota máximo operacional & $752,50 \mathrm{~m}$ \\
\hline Cota máximo normal & $757,50 \mathrm{~m}$ \\
\hline Cota máximo maximorum & $758,50 \mathrm{~m}$ \\
\hline Cota da crista & $760 \mathrm{~m}$ \\
\hline Comprimento da barragem & $500 \mathrm{~m}$ \\
\hline Altura máxima da barragem 2 & $6 m$ \\
\hline
\end{tabular}

Fonte: DAEE, 2007

\subsubsection{Localização do Reservatório}

O município de Biritiba-Mirim está localizado na Região Metropolitana de São Paulo (RMSP) e faz parte da Unidade de Gerenciamento de Recursos Hídricos (UGRHI) 6 do Alto Tietê. O reservatório de Biritiba-Mirim é formado pelo represamento das águas do rio Biritiba-Mirim, afluente da margem esquerda do Rio Tietê. A partir de São Paulo segue-se para o reservatório via rodovia Ayrton Senna (SP - 70), seguida pela Rodovia Pedro Eroles ( $\mathrm{SP}$ - 88), até a chegada ao município de Biritiba - Mirim (Figuras 2 e 3). 

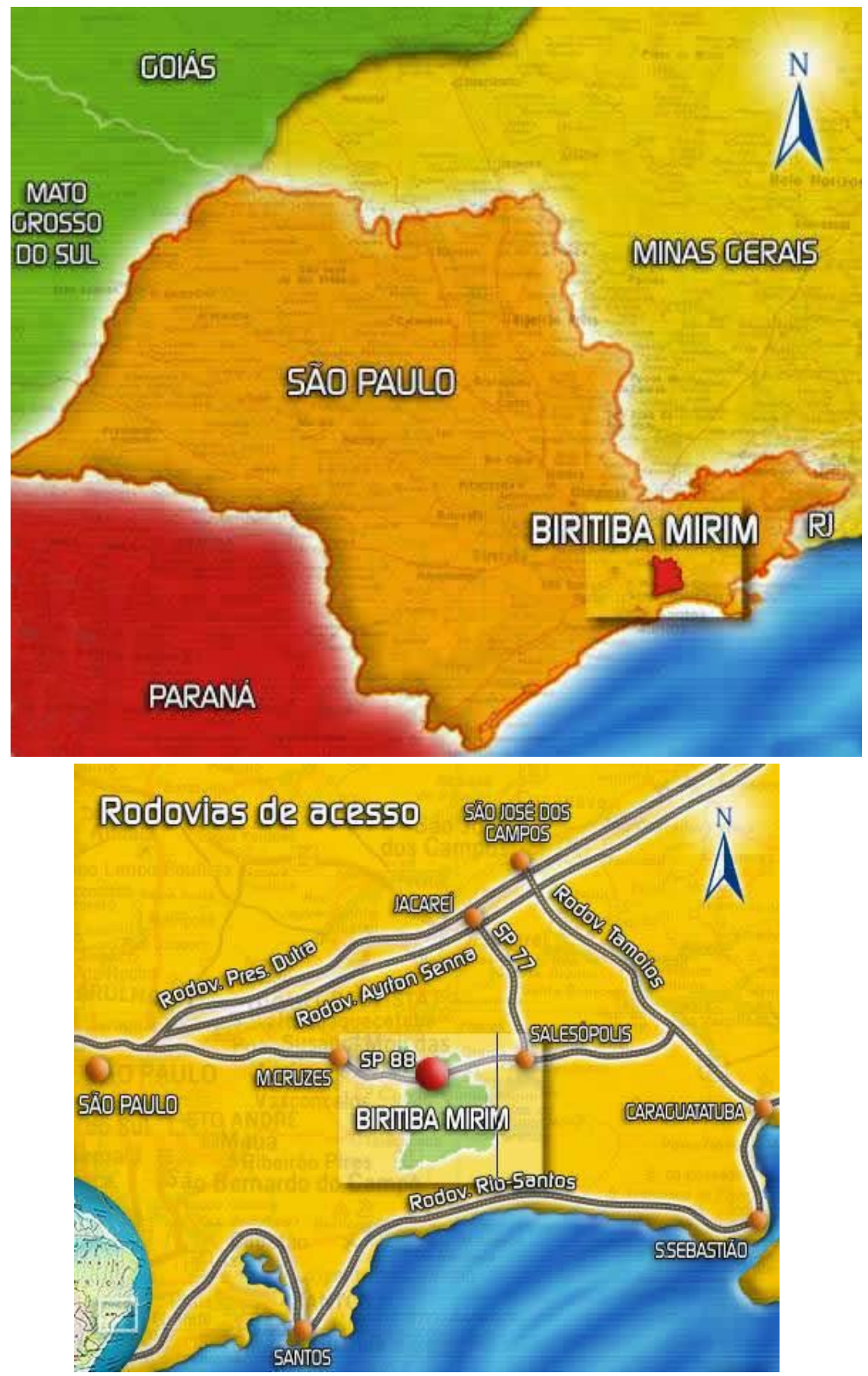

Figura 2 - Localização do município de Biritiba Mirim no Estado de São Paulo e rodovias de acesso até o reservatório de Biritiba-Mirim.

Fonte: http://www.camarabiritibamirim.sp.gov.br. Acessado em 13 de julho de 2015. 


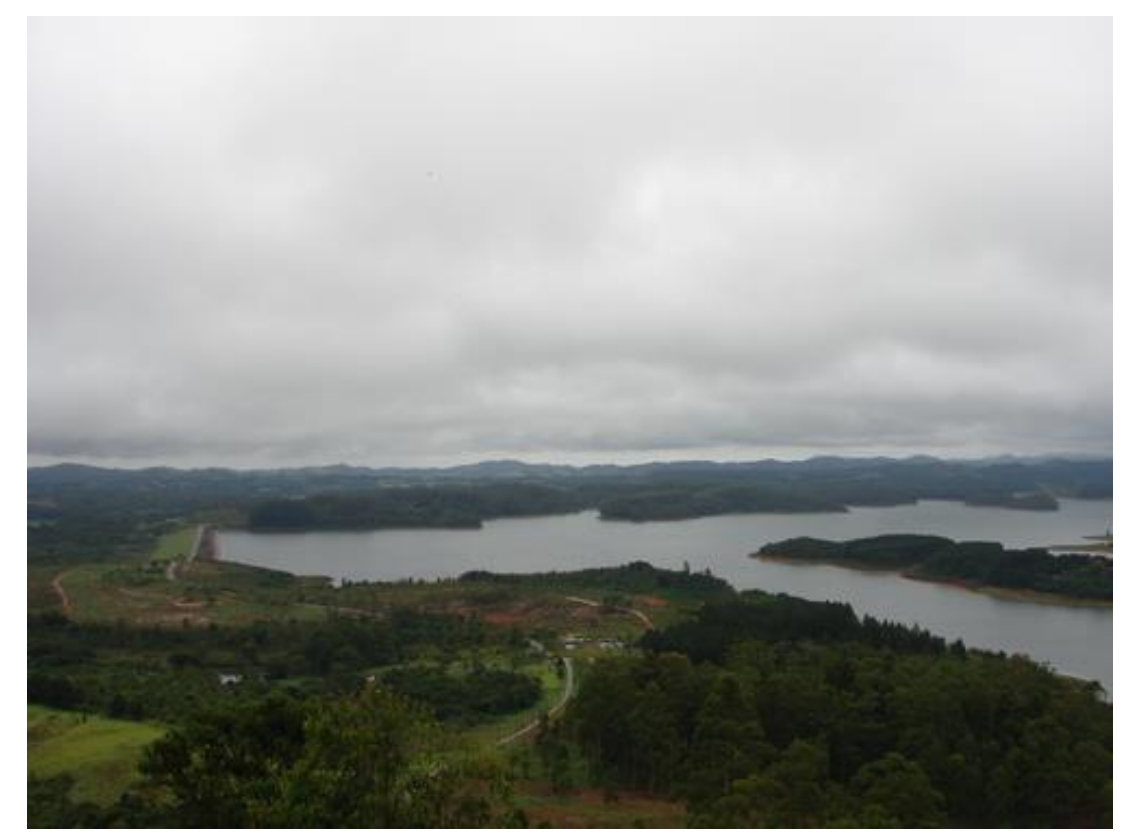

Figura 3 - Foto com a vista do reservatório de Biritiba-Mirim. Fonte: http://www.panoramio.com. Acessado em 13 de julho de 2015.

\subsubsection{Características Climáticas}

Biritiba -Mirim está localizada em uma região de clima subtropical, como toda a Região Metropolitana de São Paulo. As temperaturas anuais atingem em média $20^{\circ} \mathrm{C}$, sendo Julho o mês mais frio, com média de $15^{\circ} \mathrm{C}$, enquanto Fevereiro é o mês mais quente, com tem média de $23^{\circ} \mathrm{C}$ (Prefeitura Municipal de Biritiba - Mirim, 2014). A época chuvosa ocorre entre os meses de outubro a março, enquanto os períodos mais secos ocorrem entre abril e setembro (Figura 4).

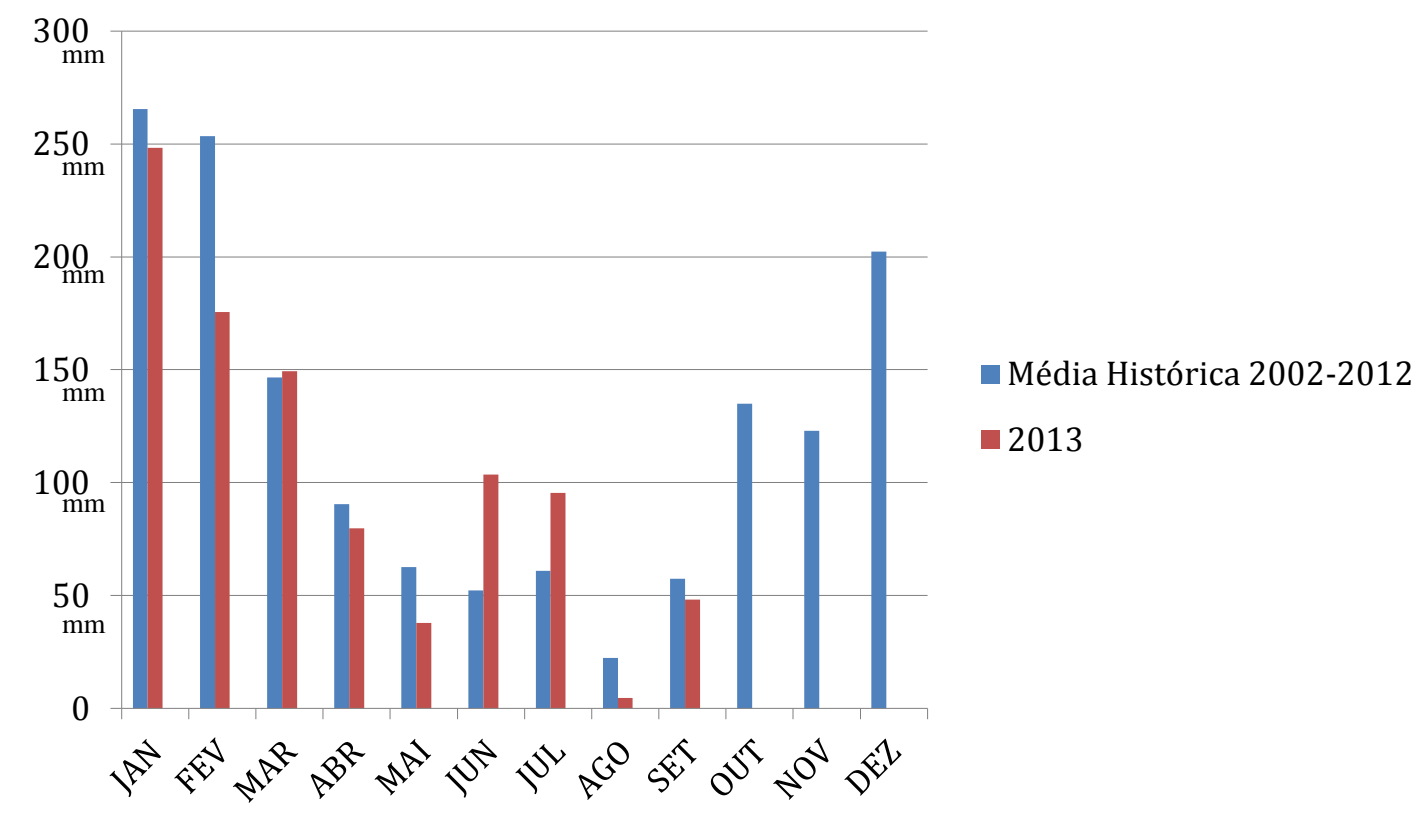

Figura 4 - Intensidades de chuva mensais e anuais no Reservatório de Biritiba Mirim. O eixo das ordenadas representa a precipitação $(\mathrm{mm})$ e o eixo das abcissas os meses do ano. Fonte: DAEE - barragem de Biritiba-Mirim. 
Para a realização da análise do índice pluviométrico do reservatório de Biritiba-Mirim foram utilizados os dados fornecido pelo DAAE - barragem de Biritiba, que constavam de valores das médias mensais desde o ano de 1997 até o mês de setembro de 2013. Foi realizada uma média histórica no período de 11 anos, entre 2002 a 2012, e confrontados estes dados com os índices dos meses do ano de 2013, conforme apresentado na Figura 4.

A Figura 4 mostra que na média histórica no período de 2002 a 2012, os meses mais secos estão entre abril e setembro e a época chuvosa se estende de outubro a março. Porém, os dados coletados em 2013, mostram que no período de seca, com precipitações mensais inferiores a $100 \mathrm{~mm}$, apresentaram resultados singulares este ano, pois houve um aumento de intensidade pluviométrica atípico nos meses de junho e julho, que coincidiram com o período de coleta do presente estudo.

Ainda é possível observar que os volumes superiores à média pluviométrica precipitados em junho e julho de 2013 foram compensados pelos menores índices pluviométricos ocorridos nos demais meses deste ano. Até o momento foi constatado que janeiro foi o mês com maior índice pluviométrico, acompanhando a média histórica, enquanto agosto foi o mais seco, com apenas $4,70 \mathrm{~mm}$ de chuva registrada (Figura 4).

\subsubsection{Características Geológicas}

A região onde está inserida a área de estudo caracteriza-se por apresentar unidades provenientes de diferentes eventos tectônicos e de diversidade litológica também distintas. Basicamente subdividida em dois grandes grupos, as unidades mais antigas que fazem parte do Complexo Embu e, as unidades que compreendem rochas graníticas granitóides a corpos graníticos mais modernos (Companhia de Pesquisas de Recursos Minerais - CPRM, 1990). As unidades mais frequentes aflorantes da área do reservatório de Biritiba-Mirim estão expressas na figura 5.

A área do reservatório foco desse estudo está inserida na porção Leste do Planalto Paulistano que corresponde aos domínios do Complexo Costeiro, localizado na porção Sul e em uma faixa alongada que se estende de centro-oeste a nordeste, representado por rochas migmatíticas $(\mathrm{Ay} 0+1)$ de aspecto textural distinto, associados a gnaisses graníticos e corpos biotíticos. Atribuído a este mesmo 
complexo, ao sul ocorrem rochas graníticas de textura porfiróide (Ay0), estando associadas a gnaisses e migmatíticos (CPRM, 1990).

Ao longo das principais drenagens do reservatório encontram-se as unidades mais recentes onde se destacam os depósitos fluviais (Qha), que são constituídos por camadas argilosas, ricas em material orgânico, areias inconsolidadas de granulometria variada e cascalhos. Sua extensão é restrita nos afluentes secundários, e nas áreas de relevo acentuado (CCN,1997).

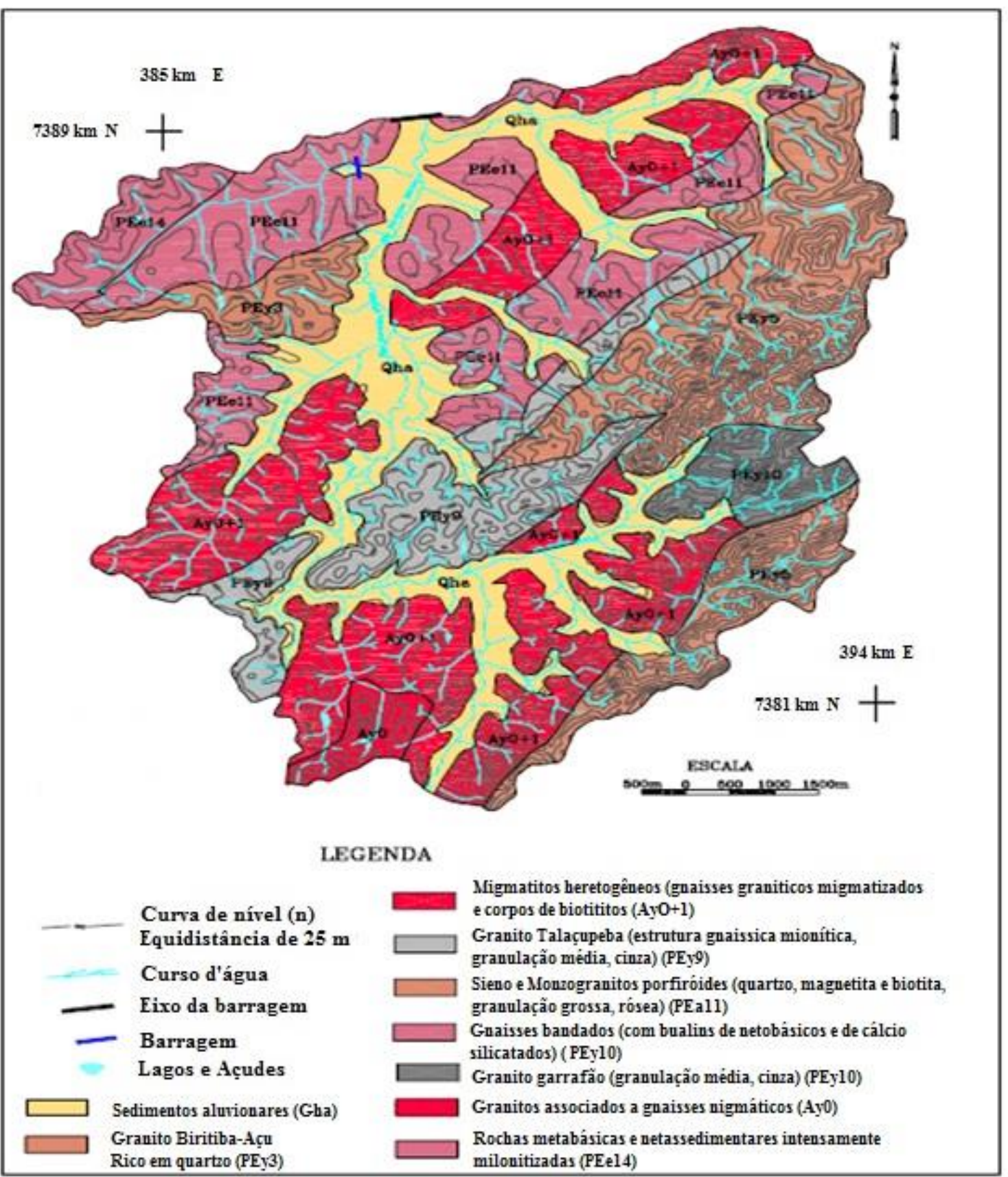

Figura 5 - Unidades geológicas aflorantes na área do reservatório de Biritiba-Mirim. (Fonte: Monteiro, 2006). 


\subsubsection{Características Hidrogeológicas}

O reservatório de Biritiba-Mirim integra a bacia hidrográfica do Alto Tietê, localizada na região Leste do Estado de São Paulo. Nesta área encontram-se rochas do embasamento e sedimentos Quaternários das áreas de inundação, constituindo o Sistema Aquífero Cristalino (SAC) e o Sistema Aquífero Sedimentar (SAS). O primeiro está associado a granitos e rochas metamórficas do embasamento e relacionadas ao Complexo Embu, Grupo São Roque e Serra de Itaberaba. Neste tipo de Aquífero a água explotável pode ocorrer nas falhas, fraturas ou no manto de alteração das rochas cristalinas, podendo ser diferenciados pelas características presentes, uma vez que a água pode escoar somente nas descontinuidades rúpteis da rocha; enquanto que na rocha semi-alterada a textura pode ser identificada e ainda possuir um grau de resistência; e quando ocorre alteração total da rocha, o escoamento ocorre nos interstícios da rocha intemperizada, e decomposição total dos minerais (CAVALCANTI, 2002).

$\mathrm{Na}$ região de Mogi das Cruzes e suas vizinhanças, o aqüífero cristalino apresenta profundidade aproximada de 120 a 150 metros na RMSP e exibe capacidade específica média de $0,24 \mathrm{~m}^{3} / \mathrm{h} / \mathrm{m}$ e a transmissividade ao redor de 0,4 e 14 $\mathrm{m}^{2} /$ dia e entre 0,5 e $5 \%$ do coeficiente de armazenamento (DAEE, 1975). Ainda segundo Cavalcanti (2002), o Sistema Aquífero Sedimentar é formado por depósitos sedimentares aluviais predominantemente areno-argilosos e sedimentos Quaternários e Terciários da Bacia de São Paulo, ocupam planícies das principais drenagens da área, apresentando larguras irregulares de 200 a 1000 metros, e espessura média da ordem de 7 metros (Figura 6). 


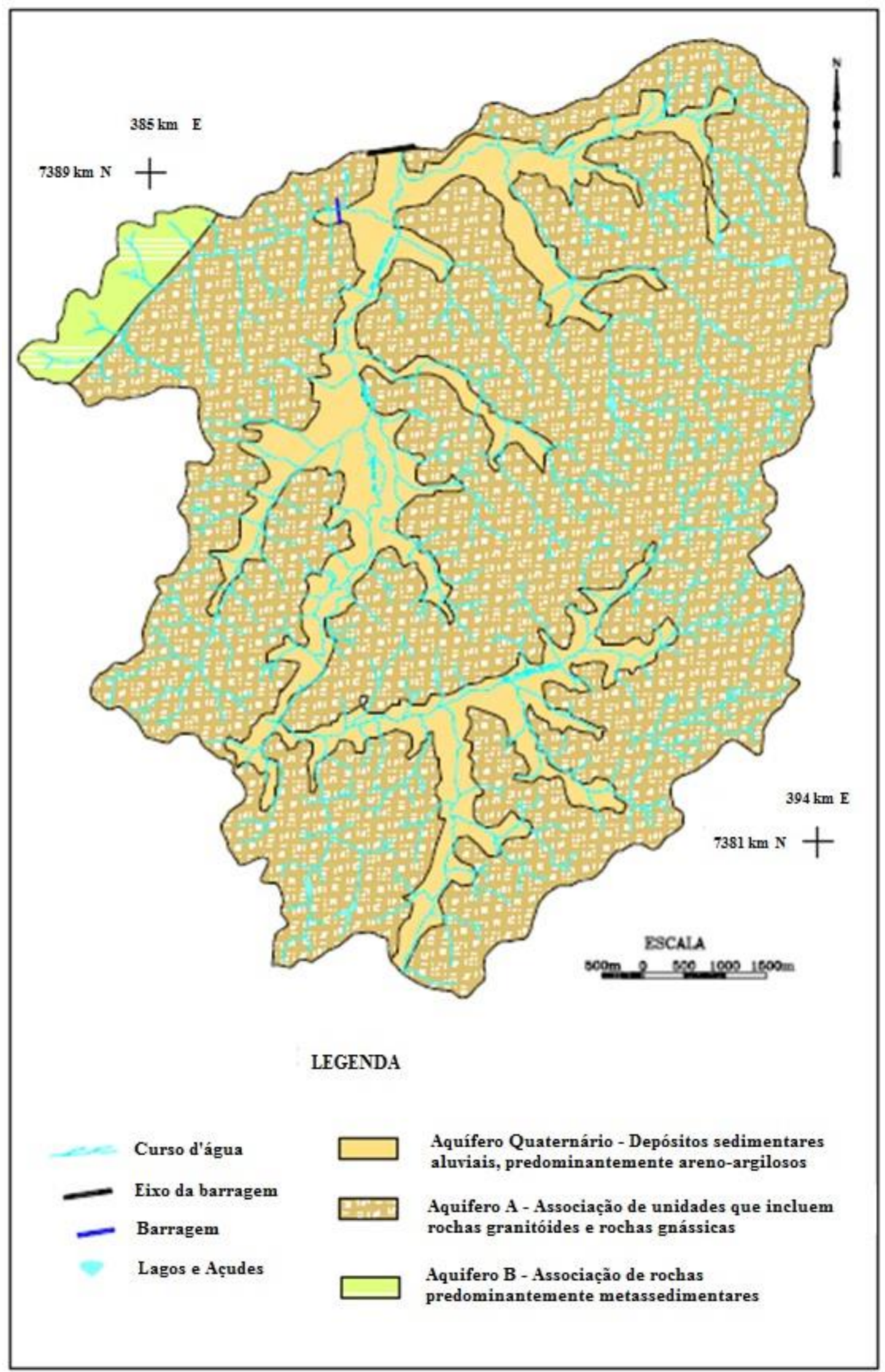

Figura 6 - Mapa hidrogeológico da área de estudo. (Fonte: modificado de Cavalcanti, 2002). 


\subsubsection{Características Pedológicas}

Para CCN (1997) a região onde está localizado o reservatório de BiritibaMirim não apresenta mapeamento pedológico atualizado em escala que admita a obtenção de informações para descrição e análise detalhada dos recursos de solos. Contudo, podem ser caracterizados alguns tipos de solos que são encontrados na área de estudo, como por exemplo, Podzólico vermelho-amarelo, Latossolo vermelhoAmarelo, Latossolo vermelho-escuro, Cambissolo e Glei pouco húmico.

O solo Podzólico vermelho-amarelo é caracterizado por apresentar grande acúmulo de argilas nas camadas superficiais. São solos minerais com horizonte B textural, não hidromórfico, com sequência de horizontes A, B e C, moderadamente drenados. Já os Latossolos caracterizam-se por apresentarem predominância em argilominerais, não hidromórficos, que variam de espessura entre próximos de dezena de metros a métricos, com estágio avançado de intemperização. O Latossolo vermelho-escuro apresenta maior concentração de hidróxido de ferro e coloração mais avermelhada quando comparado ao Latossolo vermelho-amarelo (CCN, 1997).

Os Cambissolos são solos minerais não hidromórficos e de textura argilosa, de caráter ácido, apresentam horizonte B e ocorrem em relevos acidentados. Ainda segundo CCN (1997), os solos Glei pouco húmico desenvolvem-se em condições de umidade excessiva e deficiência de oxigenação, formando um horizonte superficial de coloração acinzentada. Geralmente são formados em áreas planas e topograficamente baixas.

\subsubsection{Características Geomorfológicas}

Biritiba-Mirim está situada na extremidade leste do Planalto Paulistano, limitada a sudoeste pelo planalto Paraitinga/Paraibuna, sendo ambos integrantes da unidade morfoestrututal do planalto Atlântico (ROSS e MOROZ, 1997). As principais drenagens ao longo do reservatório são evidenciadas pelo controle das estruturas das rochas do embasamento cristalino, na figura 7; e tem como característica principal a presença marcante de terrenos baixos e inclinados em 
direção ao canal, caracterizando uma planície fluvial. Este sistema está associado a áreas alagadas e pantanosas, havendo variação das altitudes com o relevo em que ocorrem (CCN, 1997).

Segundo PIRES NETO (1992), na cabeceira do rio Biritiba há paisagens constituídas por relevo de morros, serras e montanhas superiores a 100m e declividades médias e altas. No entanto, o restante da bacia apresenta zona de baixo curso, com predomínio de relevos de Colinas e Morrotes e Planícies Fluviais, sendo que em algumas porções há ocorrência de relevos de Morrotes e Morros e Morrotes Paralelos.

A agricultura se beneficia com esta região já que a unidade do Complexo Embu é de reconhecida fertilidade, além de ser composta por relevos de colinas e morrotes com declividades baixas, entre 10 e $15 \%$ e altitudes variáveis de 780 a 800 m, sendo sua amplitude entre 30 e 75 m (CAVALCANTI, 2002). Neste sentido, há remoção dos produtos aplicados no solo devido à diminuição do escoamento superficial.

Unidades menos significativas também estão presentes nesta área, ainda que em menor proporção. Os morrotes paralelos apresentam seus topos e vales estreitos, com padrão de drenagem em treliça e paralelo de alta densidade, enquanto morrotes e morros formam topos amplos, convexos e forma de topos estreitos, sendo estes últimos o padrão de drenagem dentrítico e subparalelo, de media e alta densidade. Nos morrotes paralelos encontramos uma amplitude de 40 a $90 \mathrm{~m}$ e vertentes com declividades de 23 a 50\%, já nos morrotes e morros as amplitudes são de 60 a 160 m e possuem vertentes com declividade entre 13 e 40\% (CAVALCANTI, 2002) (Figura 7). 


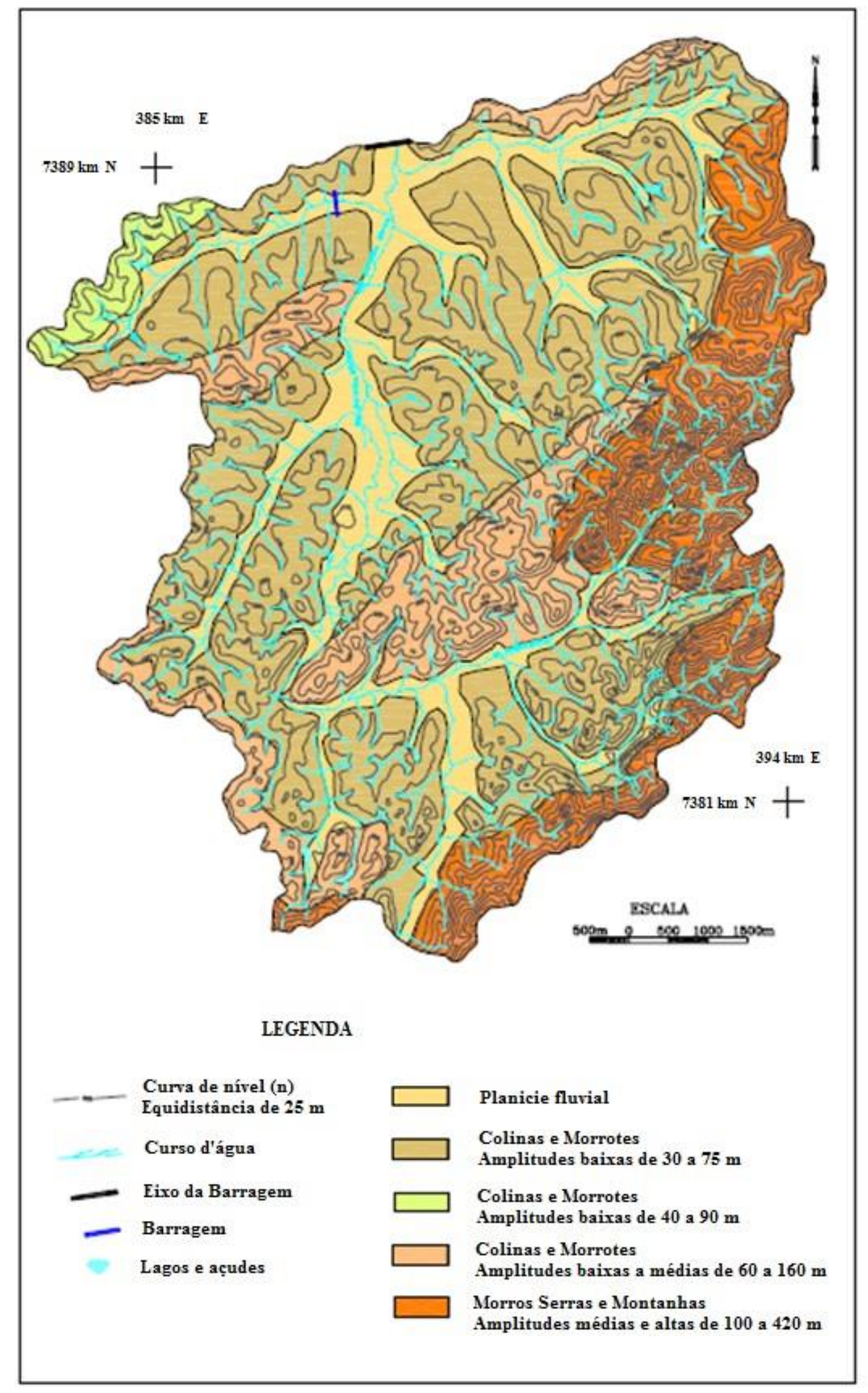

Figura 7 - Unidades geomorfológicas presentes na área de estudo. (Fonte: Monteiro,2006). 


\section{MATERIAIS E MÉTODOS}

\section{1 - Trabalhos de Campo.}

Foram realizadas três campanhas de campo. Na primeira campanha foi realizada a caracterização do local do estudo, nas segunda e terceira campanha foi realizada e seleção dos pontos de amostragem e a coleta das amostras de água e sedimentos de fundo. Foi cedido pela SABESP o equipamento de infraestrutura para a navegação no interior do reservatório. Para o critério de escolha dos pontos de coleta das amostras da área PB (ponto branco) o ponto escolhido é o que atualmente vem sendo utilizado para coleta de água pela SABESP, uma vez que este é o local utilizado pelo próprio órgão estadual como ponto de referência. A definição dos locais de coleta tiveram como critério a existência de atividades antrópicas (agricultura etc) de um lado e de outro área protegida por mata nativa buscando comparar os resultados de uma com a outra. Considerando que as áreas com atividades agrícolas são uma fonte potencialmente contaminante pelo uso de aditivos e defensivos agrícolas.

As amostras de água e sedimentos de fundo foram coletadas em dez pontos diferentes de amostragem com o auxílio de um coletor Kajack Brinkhust modificado. Cinco destas amostras da região proximal à atividade agrícola e cinco da região protegida por vegetação nativa. Os sedimentos e a água coletados foram armazenados em reservatório contendo gelo e mantido a cerca de $4^{\circ} \mathrm{C}$, sendo o sedimento em sacos de polietileno e a água em tubo de polietileno de $50 \mathrm{~mL}$.

Após a escolha dos locais de coleta, foram realizadas medidas de distâncias de 50 metros entre um ponto e outro, nos quais foram efetivadas marcações georreferenciadas com o auxílio de um GPS marca GARMIM, modelo 12XL.

\section{2- Medição de Parâmetros Físico-Químicos da Água}

Foram realizadas determinações analíticas "in situ" por meio de Sonda Multiparâmetro Modelo YSI 6820 V2 (Figura. 8) que utiliza sensores com tecnologia aprovada pelo USEPA através do protocolo Environmental Technology Verification Program (ETV), cedida pela SABESP para essas determinações. Foram médidos os seguintes parâmetros físico-químicos da água: Temperatura $\left(\mathrm{T}^{\circ} \mathrm{C}\right)$, Turbidez, Potencial Hidrogeniônico (pH), Oxigênio Dissolvido (OD), Condutividade Elétrica (CE) e Potencial de Oxirredução (ORP). 

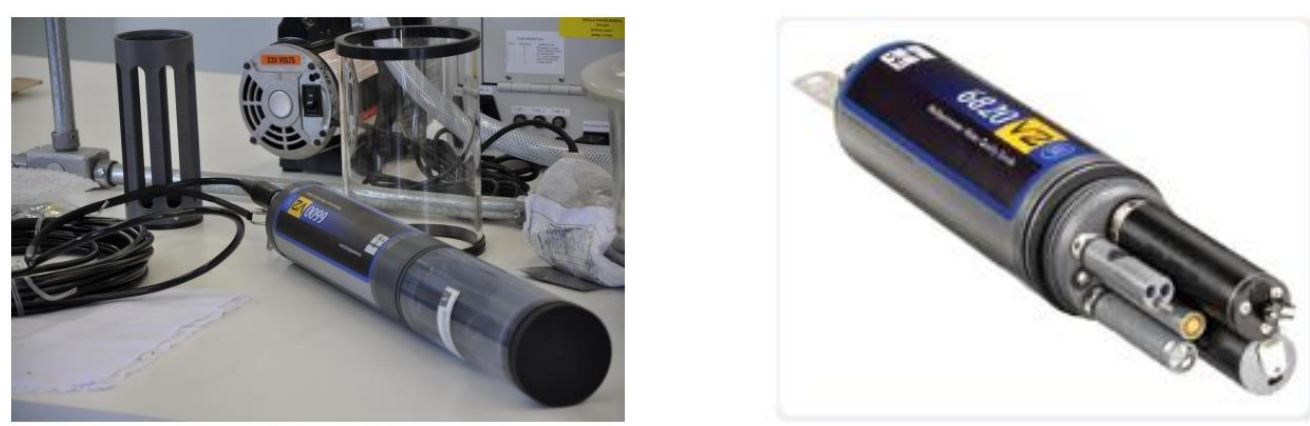

Figura 8 - Imagens da Sonda Multiparâmetro Modelo YSI 6820 V2, para determinação de parâmetros "in situ" na Represa Biritiba-Mirim.

Fonte: http://www.clean.com.br/site/sonda-ysi-6820-v2/

\section{3 - Trabalhos de Laboratório}

\subsection{1 - Procedimentos analíticos para sedimentos de fundo}

As amostras de sedimentos de fundo, no momento da coleta, foram identificadas quanto à localização do ponto de coleta, nome do coletor e sigla referente à região com mata nativa, a qual foi nomeada de área "limpa" e identificada como $(\mathrm{CAL})$ e à região com possível influência de atividade agrícola, chamada área "suja" e identificada como (CAS). As amostras coletadas no ponto de referência foram denominadas PBSJ2 e PBSM2. Assim as amostras coletadas receberam a seguinte catalogação de campo: CAL 1, CAL 2, CAL 3, CAL 4, CAL 5 e CAS 1, CAS 2, CAS 3, CAS 4, CAS 5. As amostras de água foram encaminhadas para serem analisadas pelo Laboratório de Química da SABESP (segundo critérios de analíticos estabelecido por essa estatal) e as amostras de sedimentos seguiram para dois roteiros iniciais: um de determinação de umidade e granulometria e outro para análise química total multielementar.

Primeiramente, em béquer de um litro, foi realizada a pesagem de $100 \mathrm{~g}$ de cada uma das amostras de sedimento, na balança de precisão Acculab V-1200. Para a secagem, as mesmas foram colocadas na estufa à $60{ }^{\circ} \mathrm{C}$ durante 24 horas. No dia seguinte, pesaram-se novamente as amostras; com a diferença da amostra seca versus a amostra úmida obteve-se a porcentagem de água em cada uma delas. Depois, adicionou-se água oxigenada e após a exaustão de reação com a matéria orgânica (MO), deixou-se secar a amostra e executada nova pesagem. Essa diferença entre a amostra seca bruta com MO versus amostra atacada com água oxigenada permite a obtenção da porcentagem de matéria orgânica contida em cada amostra. 
Em seguida foi realizada a análise granulométrica por difração de laser com o granulômetro Malverr Mastergizer 2000. Neste processo foram adicionadas 5 gotas de pirofosfato para impedir que a amostra decante; adicionou-se a amostra à água deionizada do aparelho. Entre as análises, o béquer foi lavado 4 vezes, duas delas com água comum e duas com água deioinizada.

A figura 9 mostra a preparação das amostras de sedimento de fundo para a determinação da granulometria de sedimentos. O trabalho foi realizado no laboratório de sedimentologia do Instituto de Geociências da Universidade de São Paulo.

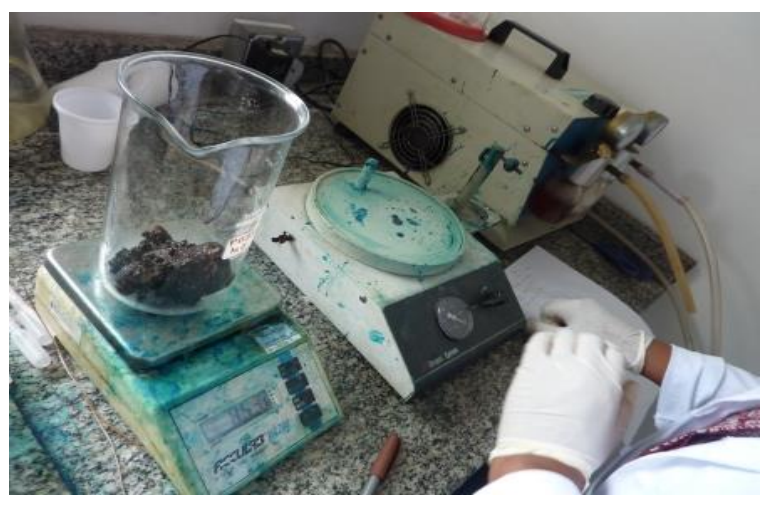

Figura 9 - Pesagem das amostras úmidas de sedimentos de fundo.

A figura 10 exibe as amostras úmidas de sedimento de fundo já pesadas, colocadas em estufa à 60 $\left.{ }^{\circ} \mathrm{C}\right)$.

Figura 10 - Amostras úmidas de sedimento de fundo em estufa à $60^{\circ} \mathrm{C}$ ) para a secagem (peso seco)
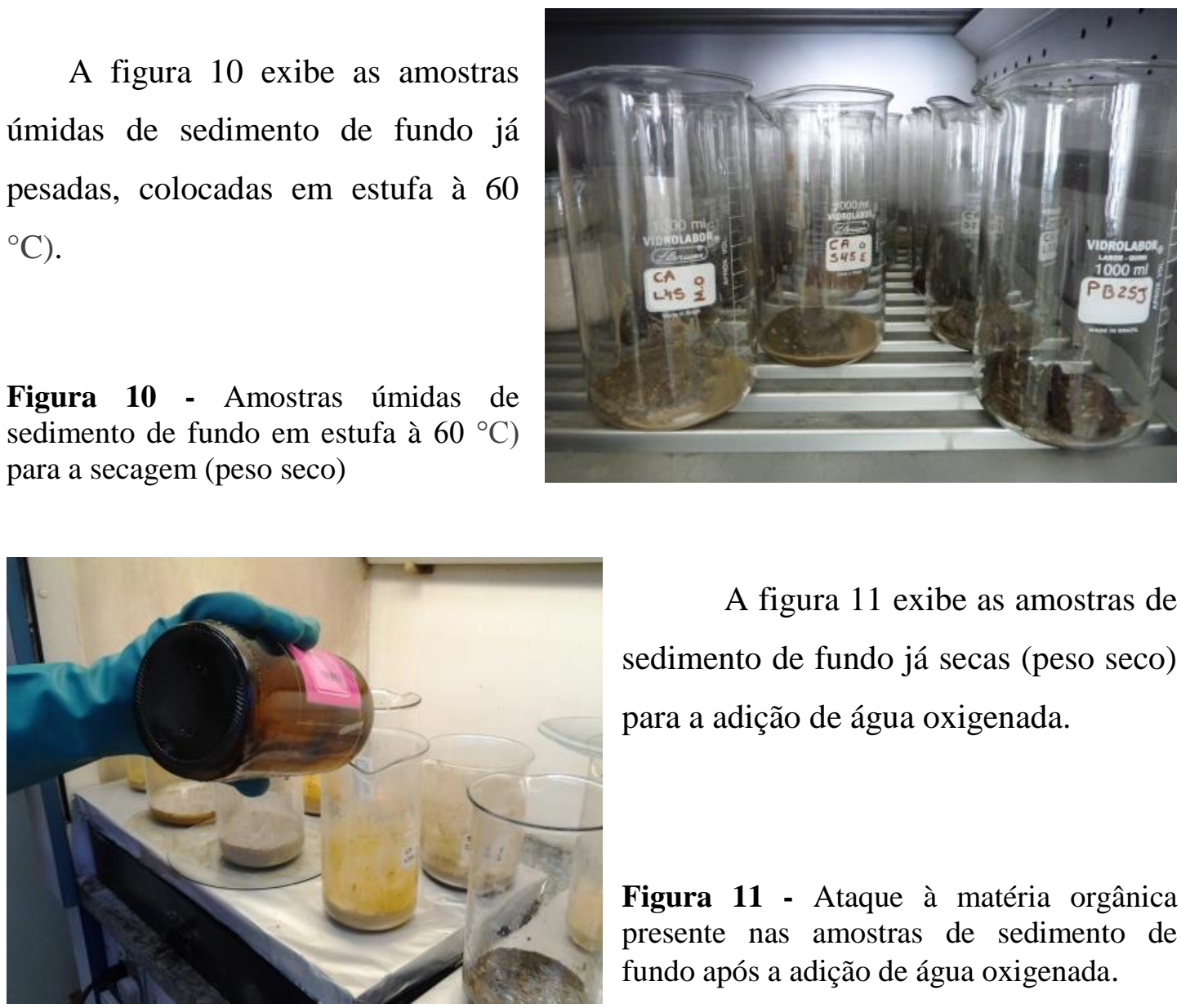

A figura 11 exibe as amostras de sedimento de fundo já secas (peso seco) para a adição de água oxigenada.

Figura 11 - Ataque à matéria orgânica presente nas amostras de sedimento de fundo após a adição de água oxigenada. 
A figura 12 exibe o Malveer Mastergizer que realizou o processo de granulometria à lazer dos sedimentos de fundo.

Figura 12 - Granulometria à laser Malveer Mastergizer

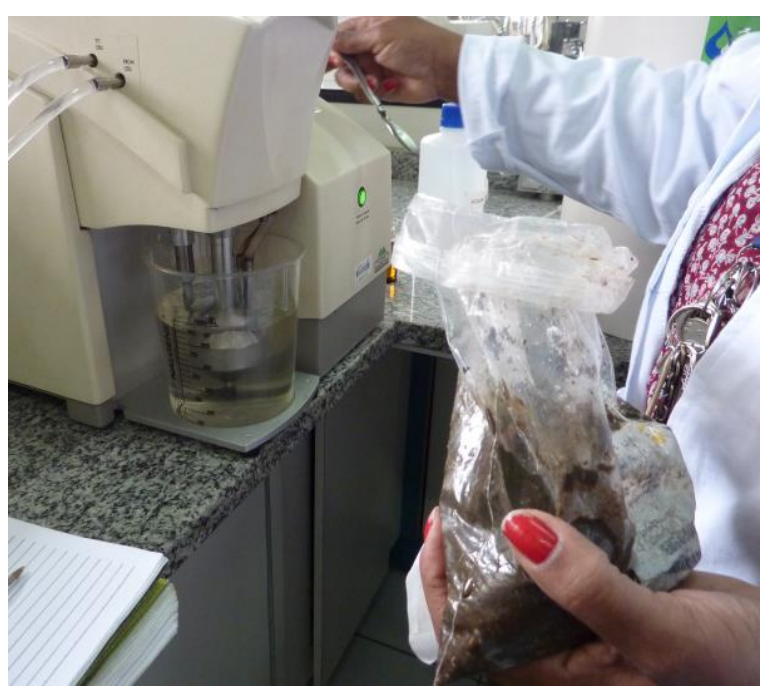

\subsection{2 - Análise Química dos Sedimentos}

Para a realização da análise química dos sedimentos, as amostras foram enviadas para o laboratório de caracterização tecnológica (LCT) da Escola Politécnica da Universidade de São Paulo, o qual realizou a determinação de alguns elementos químicos potencialmente tóxicos contidos nos sedimentos coletados. Os teores apresentados foram determinados por análises em padrões (standardless) dos elementos químicos detectados, de flúor a urânio, em espectrômetro por fluorescência de raios X Axios Advanced, marca PANalytical com perda ao fogo (PF) efetuada a $1.050{ }^{\circ} \mathrm{C}$ por $1 \mathrm{~h}$.

\subsection{3 - Análise Química da Água}

A água coletada foi encaminhada para o laboratório de química da Companhia de Saneamento Básico do Estado de São Paulo (SABESP), acreditado pela NBR ISO/IEC 17025:2005. O equipamento foi programado para analisar os seguintes elementos químicos: $\mathrm{Ag}, \mathrm{Al}, \mathrm{As}, \mathrm{Ba}, \mathrm{Ca}, \mathrm{Cd}, \mathrm{Cr}, \mathrm{Cu}, \mathrm{Fe}, \mathrm{Mg}, \mathrm{Mn}, \mathrm{Na}, \mathrm{Ni}, \mathrm{Pb}, \mathrm{Sb}, \mathrm{Se}$, Zn e P. Dessa forma, estão sendo apresentados os resultados apenas dos elementos que foram determinados em valores acima do limite de detecção do equipamento que são: $\mathrm{Al}, \mathrm{Ca}, \mathrm{Fe}, \mathrm{Mg}, \mathrm{Mn}, \mathrm{Na}, \mathrm{Zn}, \mathrm{P}$.

Os metais foram determinados por meio do equipamento de determinação por ICP OES/SWEWW (Figura 13). A determinação de ânions (parâmetro fósforo) ocorreu segundo o método SWEWW - 4500 aplicado pelo Laboratório de Análises químicas de águas da SABESP em Botucatu, método do ácido ascórbico (Figura 14) 
e o parâmetro cloreto, com emprego do equipamento DR 5000 método argentométrico (Figura 14).

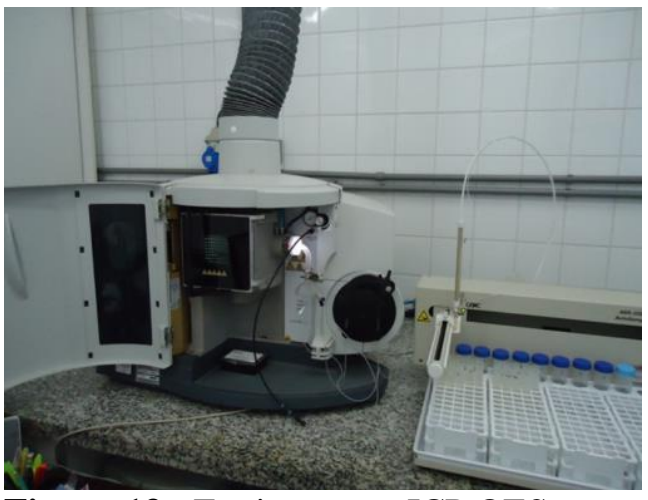

Figura 13 - Equipamento ICP OES

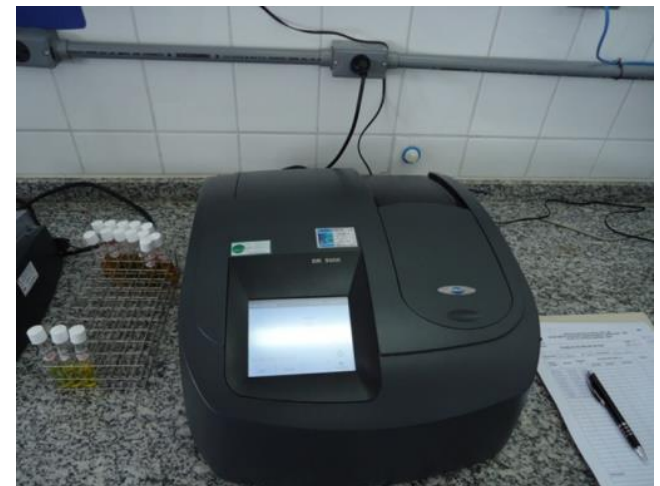

Figura 14 - Equipamento DR5000

\section{4 - Análise do Uso e Ocupação do Solo por Sensoriamento Remoto}

Primeiramente, as imagens da área de estudo foram captadas através do site do INPE (Instituto Nacional de Pesquisas Espaciais). Ambas pertencentes ao satélite LANDSAT 5, sensor TM, órbita 219, ponto 76. A primeira imagem data de 27/04/1990 e a segunda imagem de 23/05/2011, ou seja, buscou-se uma comparação quanto à evolução do tecido urbano na área em um intervalo de quase 21 anos.

Após a extração destas imagens, elas foram aproximadas para análise somente do local de interesse, região do Alto Tietê. Foi realizada uma composição colorida das duas imagens, utilizando-se as mesmas informações para ambas. Neste processo foram empregados Red-banda 2, Green - Banda 4 e Blue - banda 5.

Em seguida realizou-se o ajuste de coordenadas, tendo como referência a imagem mais nova, do ano de 2011 e as imagens foram digitalizadas para a obtenção do cálculo da área de cada reservatório, como mostra a Tabela 6.

Tabela 6. Identificação dos vetores através da digitalização dos indicadores quantitativos da água dos reservatórios

\begin{tabular}{|c|c|}
\hline IDENTIFICADOR & VETOR \\
\hline $\mathbf{1}$ & Taiaçubepa \\
\hline $\mathbf{2}$ & Jundiaí \\
\hline $\mathbf{3}$ & Biritiba-Mirim \\
\hline $\mathbf{4}$ & Ponte Nova \\
\hline $\mathbf{5}$ & Paraitinga \\
\hline
\end{tabular}


Com base na composição colorida obtida das imagens do LANDSAT 5, delimitou-se as classes de desejo para a classificação supervisionada com seu respectivo identificador (número à esquerda do nome da classe), como indicado na Tabela 7.

Tabela 7. Identificação das classes de desejo para a classificação supervisionada das imagens

\begin{tabular}{|c|c|}
\hline IDENTIFICADOR & CLASSES \\
\hline $\mathbf{1}$ & Água \\
\hline $\mathbf{2}$ & Área urbana e solo exposto \\
\hline $\mathbf{3}$ & Vegetação - Mata Atlântica Secundária \\
\hline $\mathbf{4}$ & Vegetação de Fundo de Vale \\
\hline $\mathbf{5}$ & Silvicultura \\
\hline $\mathbf{6}$ & Asfalto \\
\hline $\mathbf{7}$ & Vegetação - Mata Atlântica Primária \\
\hline $\mathbf{8}$ & Horticultura \\
\hline
\end{tabular}

Depois, realizou-se a digitalização das amostras das classes desejadas, ou seja, escolher sobre quais fatores quanto ao uso e ocupação do solo, gostaríamos de verificar modificações ao longo dos anos. Em seguida, após a transformação destas imagens em temas, foi feita a realização do cálculo de cada uma destas classes, identificando as modificações quanto ao uso e ocupação do solo ao longo do período observado. As classes de desejo foram determinadas de acordo com os dados obtidos nos filtros e por orientação dos docentes da disciplina Técnicas de Sensoriamento Remoto Aplicado à Ecologia: Fundamentos do Instituto de Biociências da USP. 


\section{RESULTADOS}

\section{1 - Trabalhos de Campo}

\subsubsection{Localização dos Pontos Coletados}

O manancial foi dividido em 2 áreas distintas para a coletada de amostras de água e sedimentos e uma área para a coleta do ponto de referência. Para a escolha destes locais levou-se em consideração as características do reservatório de BiritibaMirim, como o uso e ocupação do solo, o despejo de fontes pontuais e difusas de poluição, o provável impacto ambiental na bacia e a presença ou não de mata ciliar. As áreas escolhidas foram: i) uma área na franja de contato do reservatório com presença de atividade agrícola (indicadas com a sigla CAS), totalizando 5 pontos de coleta também definido nessa dissertação como estações de coleta e ii) uma área na franja de contato do reservatório com mata preservada (indicadas com a sigla CAL), onde foram coletadas amostras em 5 pontos, resultando em 10 estações na porção SW do Reservatório de Biriba Mirim; além de dois pontos de referência da cabeceira do rio, cuja indicação consta com a sigla PB.

A coleta foi realizada nos meses de junho e julho de 2013. Os pontos de coletas foram georreferenciados com o sistema de coordenadas UTM, Datum Sad 69 e meridiano central W $45^{\circ} 00$, dados obtidos por GPS portátil modelo Xtrex GARMIN, conforme segue os dados nas Tabelas 8, 9 e 10 na pág 40.

A figura 15 exibe o mapa aéreo do reservatório de Biritiba-Mirim. As marcações em vermelho exibem os locais de coleta de amostras de água e sedimentos de fundo. Nos cinco pontos localizados ao Norte da imagem foram coletadas as amostras em área com mata preservada e os pontos ao Sul da imagem representam a localização das amostras coletadas em área com atividade agrícola próxima ao reservatório. 


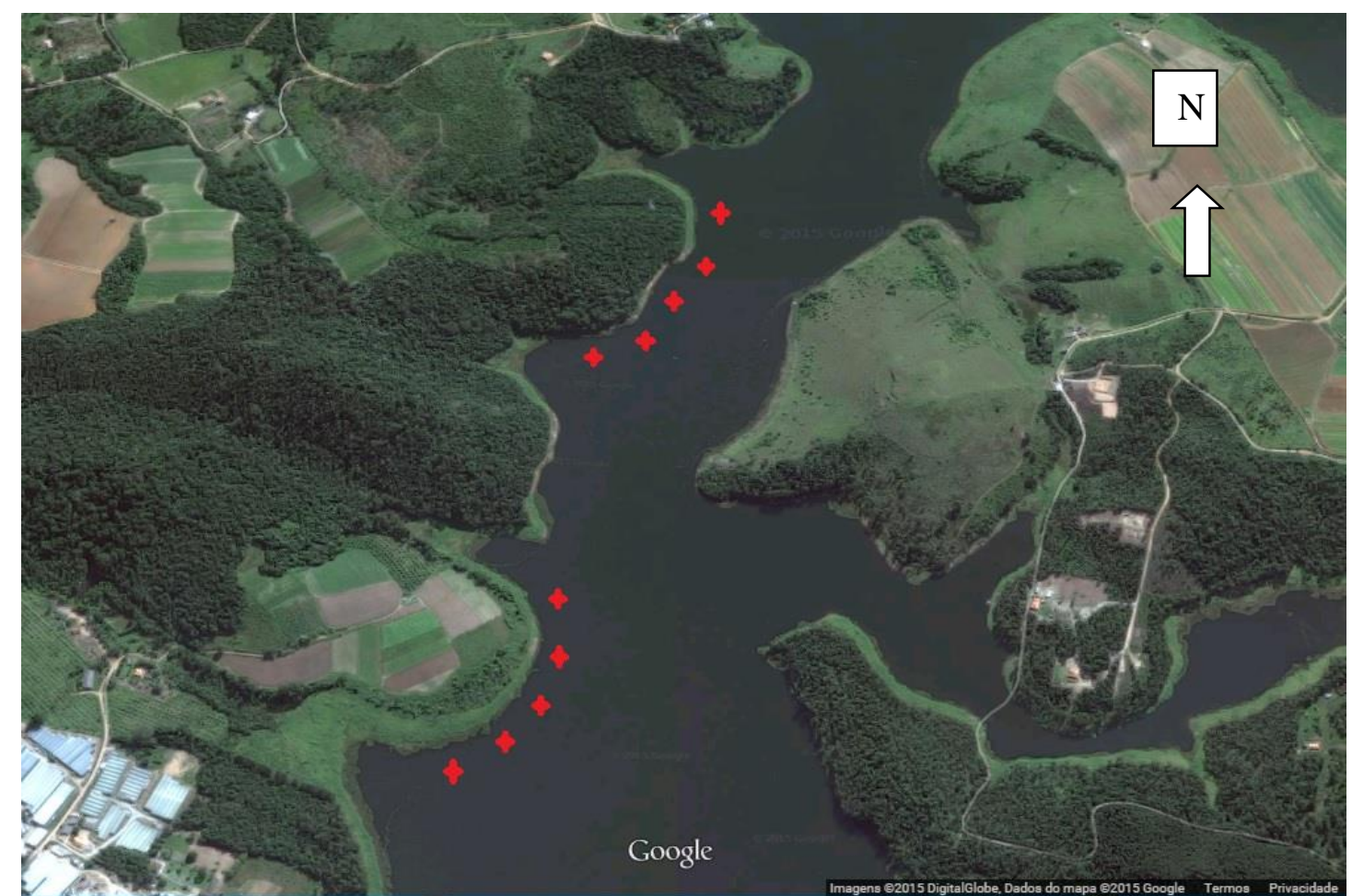

Figura 15 - Mapa de localização das áreas de amostragens no reservatório Biritiba-Mirim distanciadas em cerca de 5 metros da margem todas georeferenciadas (indicados em vermelho os locais de coleta das amostras).

Fonte: Google Maps. Sem escala. Acesso em: 20 de agosto de 2014.

A figura 16 exibe a área da cabeceira do Ribeirão Biritiba-Mirim, região considerada ponto de referência para as análises físico-químicas da água e sedimentos de fundo realizadas nessa dissertação. Nesse local foram coletados os pontos brancos, as amostra denominadas PBSJ2 e PBSM2.

Figura 16 - Ponto de referência de coleta da SABESP (visão para Leste)

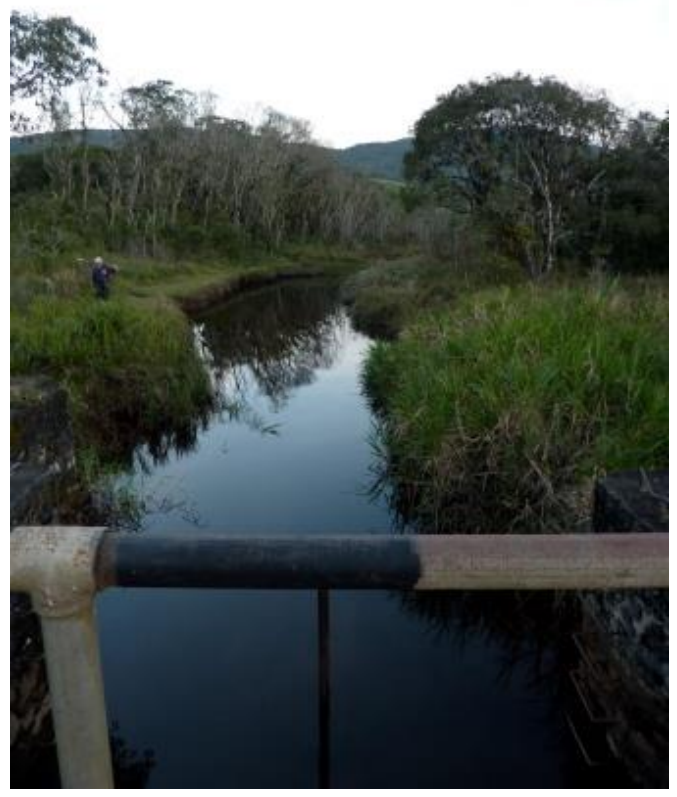




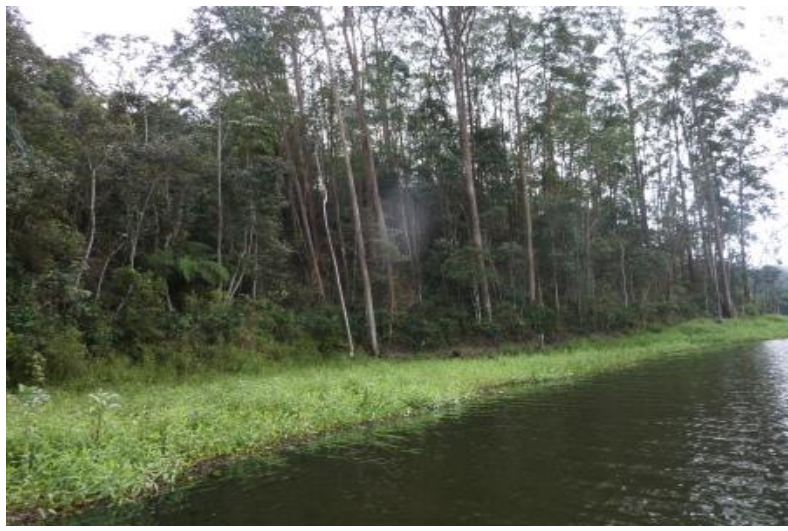

Figura 17 - Área de coleta de amostras de água e sedimentos de fundo, expondo a visão lateral para o Norte

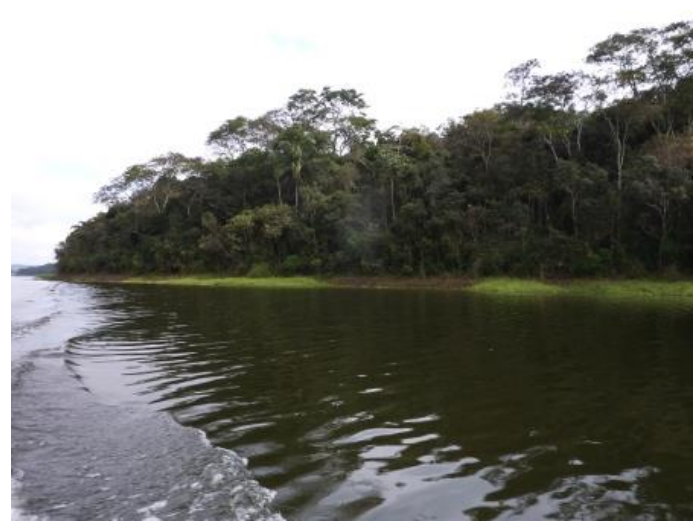

Figura 18 - Área de coleta de amostras de água e sedimentos de fundo, expondo a visão lateral para o Sul

A Figura 17 exibe a área de coleta de amostras de água e sedimentos de fundo, expondo a visão lateral para o Norte, enquanto a figura 18 exibe a visão lateral para o Sul. Ambas as figuras mostram a área de coleta de amostras em área com mata preservada, onde foram coletadas as amostras CAL1, CAL2, CAL3, CAL4 e CAL5.

As figuras 19 e 20 exibem a área de coleta de amostras de água e sedimentos de fundo, expondo a visão frontal da região. Ambas as figuras mostram a área de coleta de amostras onde há atividade agrícola próxima do reservatório. Nesse local foram coletadas as amostras CAS1, CAS2, CAS3, CAS4 e CAS5.

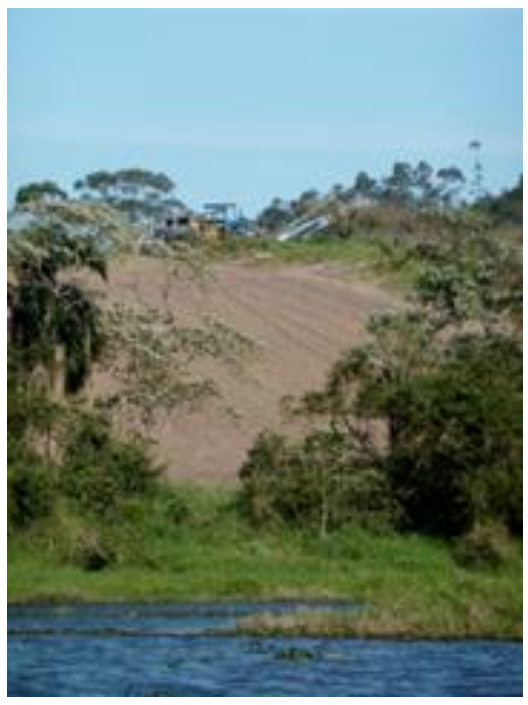

Figura 19 - Área de coleta de amostras de água e sedimentos de fundo, expondo a visão frontal -1

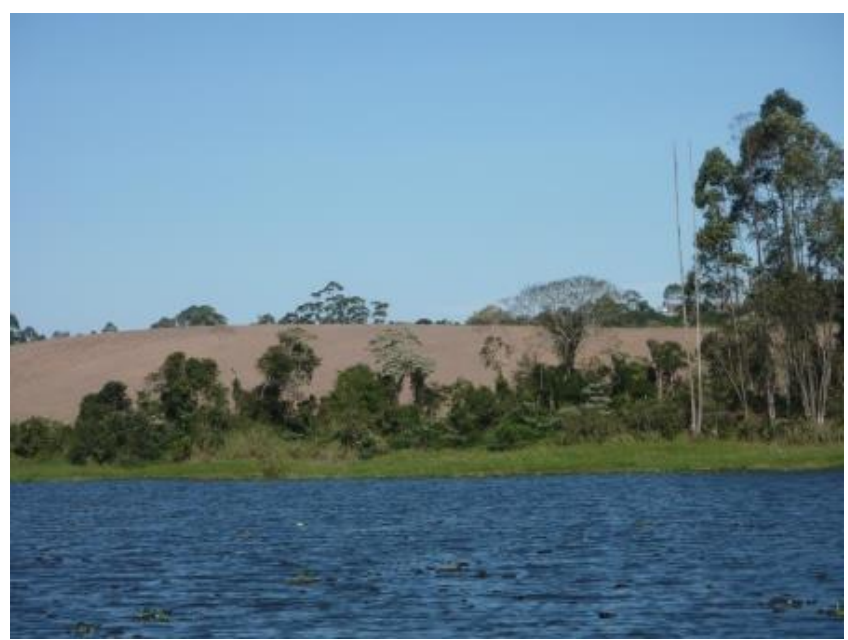

Figura 20 - Área de coleta de amostras de água e sedimentos de fundo, exibindo a visão frontal -2 
A figura 21 exibe a sonda Multiparâmetro - Modelo YSI 6820 V2 - que permitiu a determinação dos parâmetros físico-químicos da água. Anteriormente à coleta de água e sedimentos de fundo em cada ponto de coleta, a sonda multiparâmetro foi inserida na água para mensurar os valores físico-químicos referentes ao local da coleta. Também é possível perceber na superfície da água a presença de grande quantidade da planta do tipo Aguapé.

Figura 21 - Sonda Multiparâmetro - Modelo YSI $6820 \mathrm{~V} 2$
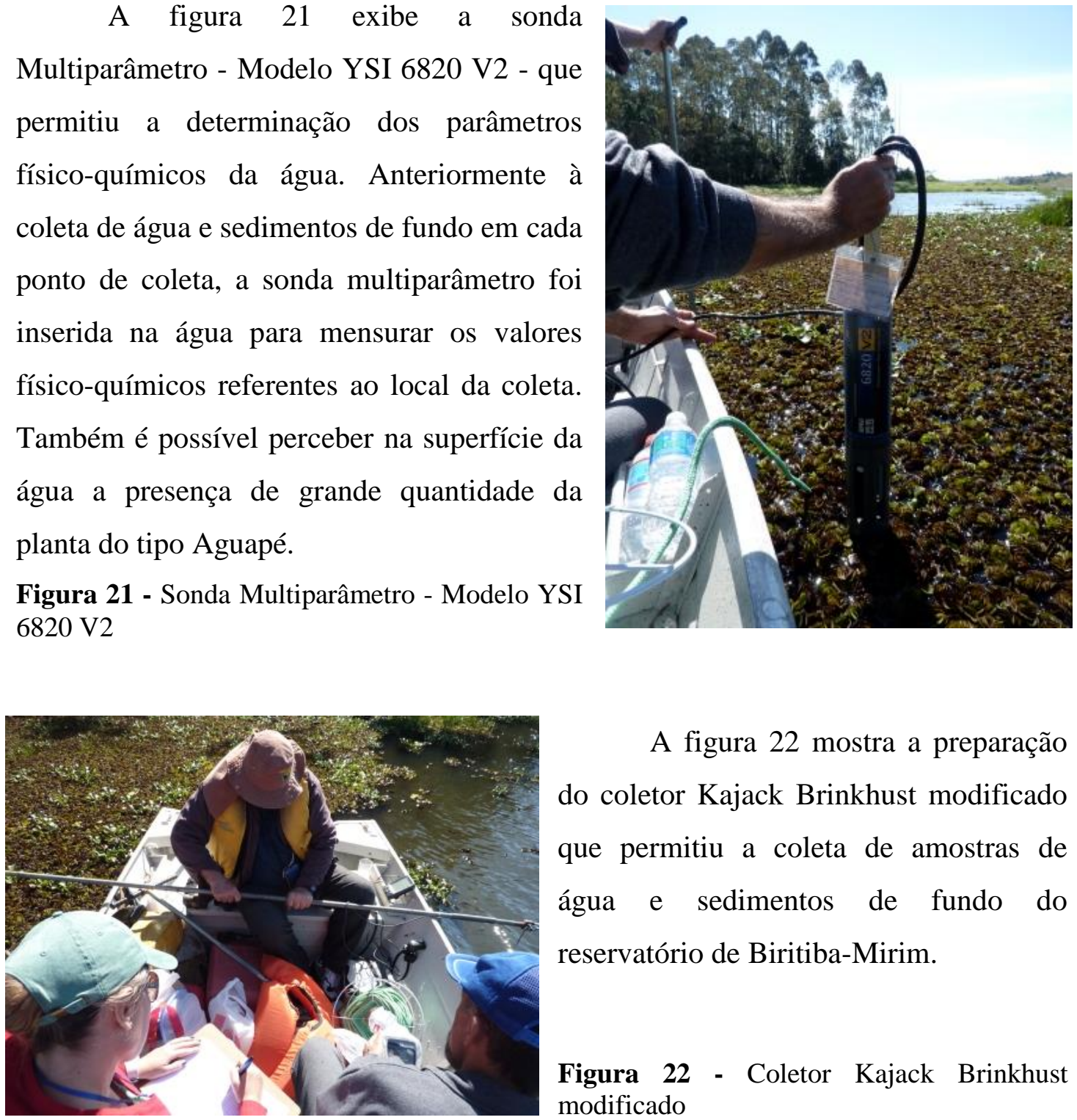

A figura 22 mostra a preparação do coletor Kajack Brinkhust modificado que permitiu a coleta de amostras de água e sedimentos de fundo do reservatório de Biritiba-Mirim.

Figura 22 - Coletor Kajack Brinkhust modificado

A figura 23 exibe a fixação do coletor Kajack Brinkhust no substrato do reservatório para a coleta de água e de sedimentos de fundo. $\mathrm{Na}$ superfície da água é possível perceber a presença de grande quantidade da planta do tipo Aguapé.

Figura 23 - Fixação do coletor Kajack Brinkhust para a coleta de água e sedimento de fundo

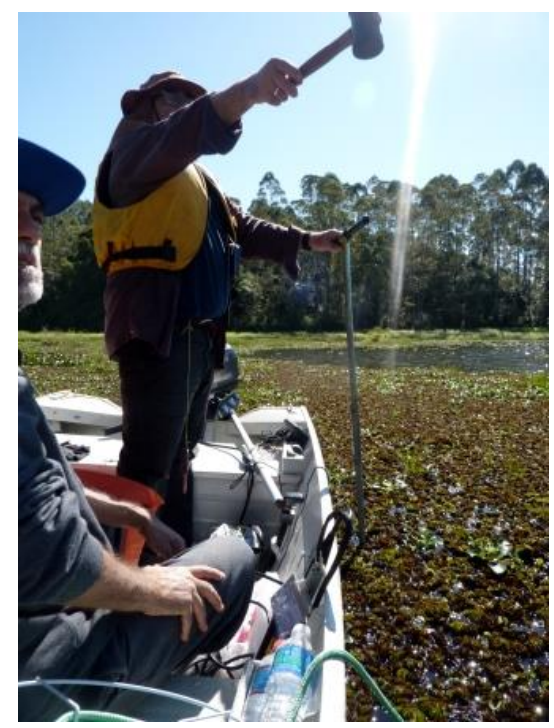




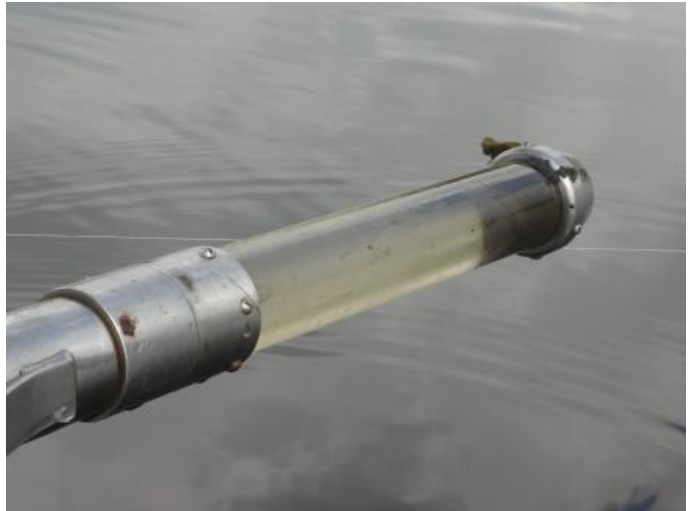

A figura 24 exibe a coleta de água e sedimentos de fundo já realizada pelo coletor Kajack Brinkhust. Dentro do coletor observa-se uma porção escura representada pelo sedimento de fundo e, a parte mais clara, a água de fundo do reservatório de Biritiba-Mirim.

Figura 24 - Coleta de água e de sedimentos de fundo

A figura 25 mostra a porção final do coletor Kajack Brinkhust que armazena o sedimento de fundo e a água do fundo do reservatório. A porção escura representa o sedimento de fundo e a porção clara, a água de fundo.

Figura 25 - Porção final do coletor Kajack Brinkhust contendo o sedimento e a água de fundo do reservatório
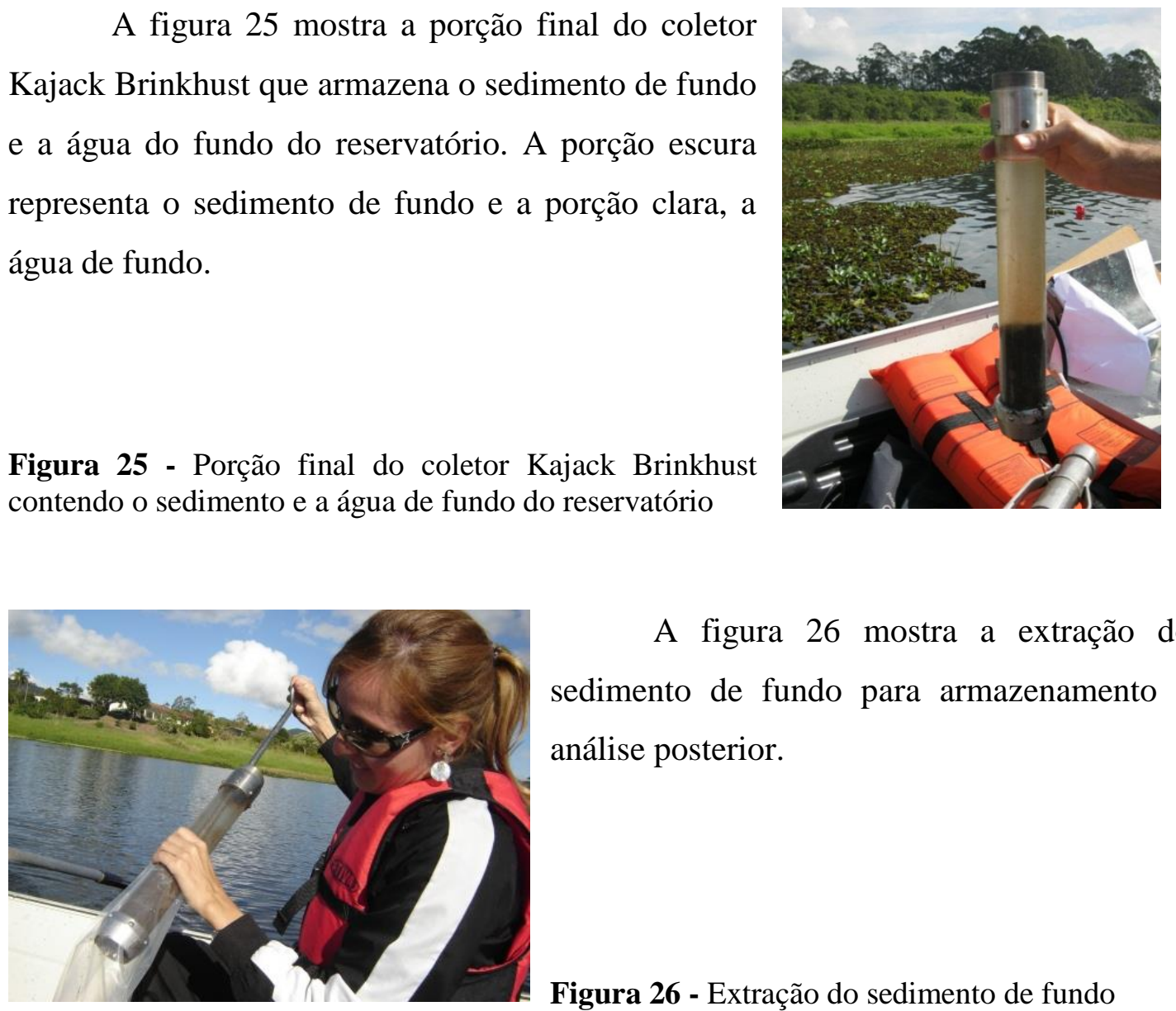

A figura 26 mostra a extração do sedimento de fundo para armazenamento e análise posterior.

Figura 26 - Extração do sedimento de fundo

\section{2- Medição de Parâmetros Físico-Químicos da Água}

A sonda modelo YSI 6820 V2 (figura 8 - pág 30) permitiu a obtenção de resultados in situ, como seguem nas tabelas abaixo. O resultado referente à área com mata nativa está expresso na tabela 8. Já a tabela 9 expressa os resultados da área com atividade agrícola e a tabela 10 mostra os resultados dos parâmetros físico- 
químicos analisados in situ, na cabeceira do rio Biritiba-Mirim (nascente), valores de referência segundo CONAMA 357/2005 e MS PORTARIA No 2914.

Ao visualizar as tabelas 8 e 9 e 10 é possível observar pequenas diferenças de pH entre as áreas, pois em ambas há mudança do $\mathrm{pH}$ de ácido para básico. Os pontos localizados na área com atividade agrícola evidenciam um pH variando de 5,4 a 6,4. Quando são comparados estes resultados com o $\mathrm{pH}$ dos pontos da área sob mata nativa observa-se que há pouca variação, sendo o valor mais baixo de 5,7 e o mais alto 6,4. No entanto, os dois pontos da área de referência apresentam certa acidez, sendo os valores de $\mathrm{pH}: 4,8$ e 5,0.

As águas de Biritiba-Mirim enquadram-se na classe 1 da resolução 357/2005 do CONAMA e nesse caso, a concentração de oxigênio dissolvido não deve ser inferior a $6 \mathrm{mg} / \mathrm{l}$. Na tabela 8 nota-se que a área com atividade agrícola não está em conformidade com este valor estabelecido pelo mesma resolução CONAMA, encontrando-se valores de 4,7 a 5,5. Na área preservada por mata nativa há dois pontos em conformidade com a resolução e os pontos de referência estão ambos de acordo com o estabelecido, ou seja, OD 7,5.

Segundo os dados da tabela 8 e 9 e 10 não houve diferença entre os valores de temperatura entre a área com mata nativa e a área com atividade agrícola, ambas permanecem ao redor de $19^{\circ} \mathrm{C}$. Já os pontos de referência, localizados na nascente, se diferenciaram dos demais por apresentarem temperaturas na média de $14,6{ }^{\circ} \mathrm{C}$.

Os valores referentes à condutividade elétrica não exibem diferenças entre os pontos localizados em área com mata nativa e os pontos em área com atividade agrícola, ambos em torno de $28 \mathrm{um} / \mathrm{cm}^{3}$ (Tabelas 8 e 9). No entanto, a condutividade foi menor nos pontos de referência, com valores entre 16 e $17 \mathrm{um} / \mathrm{cm}^{3}$ (Tabela 10).

A turbidez não apresentou diferenças entre os valores dos pontos com mata nativa e com atividade agrícola, que ficaram em torno de 6,4 a 6,8 (Tabela 8 e 9) e os valores dos pontos da nascente, 2,2 e 2,5. Ambos se enquadram na resolução 357 do CONAMA que é de 40 UNT para águas doces classe 1.

O potencial de oxirredução apresenta valores que variam entre 225,3 a 281,7 ORP, oscilando entre os pontos com mata nativa, com atividade agrícola e nos pontos da nascente (Tabelas 8,9 e 10). 
Tabela 8. Valores dos parâmetros físico-químicos da água da porção SW do Reservatório de Biritiba-Mirim (SP), em área protegida por área preservada

\begin{tabular}{|c|c|c|c|c|c|c|c|}
\hline PONTO & $\begin{array}{c}\text { PROFUNDIDADE } \\
(\mathbf{m})\end{array}$ & $\begin{array}{c}\text { TEMPERATURA } \\
\left({ }^{\circ} \mathbf{C}\right)\end{array}$ & $\mathbf{p H}$ & $\begin{array}{c}\mathbf{C E} \\
\left(\mathbf{u m} / \mathbf{c m}^{3}\right)\end{array}$ & ORP & OD (mg/L) & $\begin{array}{c}\text { TURBIDEZ } \\
(\mathbf{N T U})\end{array}$ \\
\hline CAL1 & 1,6 & 19,10 & 6,25 & 28 & 247,7 & 5,63 & 6,8 \\
\hline CAL2 & 1,7 & 19,09 & 5,77 & 28 & 274,9 & 5,73 & 6,6 \\
\hline CAL3 & 1,7 & 19,11 & 5,89 & 28 & 281,7 & 5,78 & 6,6 \\
\hline CAL4 & 1,7 & 19,25 & 6,42 & 28 & 225,3 & 6,19 & 6,7 \\
\hline CAL5 & 2,7 & 19,03 & 7,64 & 29 & 263,5 & 6,28 & 6,5 \\
\hline
\end{tabular}

Tabela 9. Valores dos parâmetros físico-químicos da água da porção SW do Reservatório de Biritiba-Mirim(SP) em área próxima ao reservatório com atividade agrícola

\begin{tabular}{|c|c|c|c|c|c|c|c|}
\hline PONTO & $\begin{array}{c}\text { PROFUNDIDADE } \\
(\mathbf{m})\end{array}$ & $\begin{array}{c}\text { TEMPERATURA } \\
\left({ }^{\circ} \mathbf{C}\right)\end{array}$ & $\mathbf{p H}$ & $\begin{array}{c}\mathbf{C E} \\
\left(\mathbf{u m} / \mathbf{c m}^{3}\right)\end{array}$ & ORP & OD (mg/L) & $\begin{array}{c}\text { TURBIDEZ } \\
(\mathbf{N T U})\end{array}$ \\
\hline CAS1 & 1,1 & 18,76 & 5,44 & 28 & 256,7 & 5,40 & 6,4 \\
\hline CAS2 & 1,7 & 18,77 & 6,31 & 28 & 258,5 & 4,67 & 6,7 \\
\hline CAS3 & 1,7 & 18,70 & 6,40 & 28 & 253,0 & 4,73 & 6,7 \\
\hline CAS4 & 2,5 & 18,72 & 6,32 & 28 & 258,3 & 4,72 & 6,5 \\
\hline CAS5 & 2,4 & 18,79 & 5,46 & 28 & 238,3 & 5,50 & 6,5 \\
\hline
\end{tabular}

Tabela 10. Valores dos parâmetros físico-químicos da cabeceira do Ribeirão BiritibaMirim(SP), valores de referência

\begin{tabular}{|l|c|c|c|c|c|c|c|}
\hline PONTO & PROFUNDIDADE(m) & $\begin{array}{c}\text { TEMPERATURA } \\
\left({ }^{\circ} \mathbf{C}\right)\end{array}$ & $\mathbf{p H}$ & $\begin{array}{c}\mathbf{C E} \\
\left(\mathbf{u m} / \mathbf{c m}^{3}\right)\end{array}$ & $\mathbf{O R P}$ & $\begin{array}{c}\text { OD } \\
(\mathbf{m g} / \mathbf{L})\end{array}$ & $\begin{array}{c}\text { TURBIDEZ } \\
(\mathbf{N T U})\end{array}$ \\
\hline PBS2M & 1 & 14,67 & 4,84 & 16 & 237,9 & 7,57 & 2,2 \\
\hline PBS2J & 1 & 14,69 & 5,09 & 17 & 226,8 & 7,51 & 2,5 \\
\hline
\end{tabular}

\section{3 - Resultados de Matéria Orgânica (MO), umidade e granulometria}

\subsubsection{Granulometria de Sedimentos de Fundo}

Após a pesagem das amostras úmidas de sedimento de fundo, secagem em estufa e nova pesagem (peso seco), foram obtidos os resultados dos valores expressos na tabela 11 . 
Tabela 11. Peso em massa e teor de umidade de cada amostra

\begin{tabular}{|c|c|c|c|}
\hline Amostra & $\begin{array}{c}\text { Peso em } \\
\text { massa úmida } \\
(g)\end{array}$ & $\begin{array}{c}\text { Peso em massa } \\
\text { Seca }(g)\end{array}$ & $\begin{array}{c}\text { Teor de Umidade } \\
(\%)\end{array}$ \\
\hline PBSM2 & 100,4 & 76,9 & 23,4 \\
\hline PBSJ2 & 85,3 & 40,6 & 52,4 \\
\hline CA S1 & 88,9 & 57,4 & 35,4 \\
\hline CA S2 & 101,5 & 55,3 & 45,5 \\
\hline CA S3 & 103,4 & 65,3 & 36,8 \\
\hline CA S4 & 101,4 & 67,4 & 33,5 \\
\hline CA S5 & 104,7 & 76,8 & 26,6 \\
\hline CA L1 & 105,7 & 54,1 & 48,8 \\
\hline CA L2 & 102,2 & 65,8 & 35,6 \\
\hline CA L3 & 100,6 & 62,5 & 37,9 \\
\hline CA L4 & 107,3 & 58,8 & 45,2 \\
\hline CA L5 & 107,5 & 74,2 & 31,0 \\
\hline
\end{tabular}

A tabela 12 mostra os resultados da porcentagem de matéria orgânica presente em cada amostra de sedimento de fundo. Esses valores foram possíveis de serem obtidos após a pesagem do peso seco e o ataque com a água oxigenada. 
Tabela 12. Porcentagem de matéria orgânica presente nas amostras

\begin{tabular}{|c|c|c|c|}
\hline Amostra & Peso Inicial $(g)$ & Peso Final $(g)$ & \% de M.O. \\
\hline PBSM2 & 76,9 & 75,9 & 1,2 \\
\hline PBSJ2 & 40,0 & 25,2 & 38,9 \\
\hline CAS1 & 57,4 & 56,5 & 1,4 \\
\hline CAS2 & 55,3 & 51,4 & 7,0 \\
\hline CAS3 & 65,3 & 61,3 & 6,0 \\
\hline CAS4 & 67,4 & 66,0 & 1,9 \\
\hline CAS5 & 76,8 & 76,2 & 0,7 \\
\hline CAL1 & 54,1 & 49,2 & 8,9 \\
\hline CAL2 & 65,8 & 64,1 & 2,5 \\
\hline CAL3 & 62,5 & 59,9 & 4,0 \\
\hline CAL4 & 58,8 & 56,7 & 3,5 \\
\hline CAL5 & 74,2 & 65,9 & 11,1 \\
\hline
\end{tabular}

As tabelas 13a e 13b expressam, respectivamente, os resultados da análise granulométrica a laser dos sedimentos de fundo e os parâmetros estatísticos da distribuição granulométrica (phi). Os valores destacados em negrito e sublinhados aparecem mais elevados, chamando a atenção para a relação entre a composição do sedimento dessas amostras e a presença ou não de elementos químicos. 
Tabela 13a. Resultados de análise granulométrica das amostras por difração a laser

\begin{tabular}{|c|c|c|c|c|c|c|c|c|c|c|}
\hline \multirow[b]{3}{*}{ Amostra } & \multicolumn{10}{|c|}{ Faixa Granulométrica (\%) } \\
\hline & \multicolumn{5}{|c|}{ Areia } & \multicolumn{4}{|c|}{ Silte } & \multirow[b]{2}{*}{ Argila } \\
\hline & $\begin{array}{c}\text { Muito } \\
\text { Grossa }\end{array}$ & Grossa & Média & Fina & $\begin{array}{c}\text { Muito } \\
\text { Fina }\end{array}$ & Grosso & Médio & Fino & $\begin{array}{c}\text { Muito } \\
\text { Fino }\end{array}$ & \\
\hline CA S 1 & 15,2 & 12,9 & 30,6 & 19,2 & 5,2 & 4,7 & 2,4 & 3,2 & 3,1 & 6,1 \\
\hline $\mathrm{CA} \mathrm{S} 2$ & 10,8 & 9,7 & 18,6 & 9,3 & 5,4 & 4,9 & 6,5 & 9,5 & 9,2 & 15,5 \\
\hline CA S 3 & 10,0 & 8,0 & 19,7 & 22,1 & 16,5 & 7,3 & 4,4 & 3,6 & 2,7 & 5,3 \\
\hline CA S 4 & 13,2 & 12,9 & 26,0 & 12,9 & 5,2 & 3,6 & 4,7 & 5,8 & 4,8 & 10,4 \\
\hline CA S 5 & 6,0 & 6,2 & 11,5 & 9,2 & 12,4 & 11,9 & 12,1 & 11,8 & 7,2 & 11,1 \\
\hline PB SJ 2 & 0,0 & 3,7 & 31,3 & 35,4 & 12,3 & 3,9 & 3,6 & 3,3 & 2,5 & 3,6 \\
\hline CA L 1 & 3,1 & 4,7 & 14,2 & 17,8 & 17,5 & 10,7 & 8,3 & 8,1 & 5,9 & 9,3 \\
\hline CA L 2 & 5,8 & 7,7 & 19,0 & 19,5 & 17,9 & 9,2 & 5,7 & 5,3 & 3,5 & 6,0 \\
\hline $\mathrm{CA} \mathrm{L} 3$ & 4,6 & 6,4 & 20,5 & 23,1 & 16,2 & 6,5 & 4,8 & 5,2 & 3,9 & 8,3 \\
\hline CA L 4 & 7,5 & 7,8 & 18,2 & 15,0 & 10,9 & 9,8 & 10,5 & 7,3 & 4,1 & 8,3 \\
\hline CA L 5 & 6,1 & 8,6 & 18,7 & 13,6 & 10,2 & 6,4 & 7,2 & 8,6 & 6,8 & 13,3 \\
\hline PB 2 SJ & 13,9 & 17,0 & 29,0 & 10,4 & 11,4 & 7,2 & 3,2 & 2,9 & 1,9 & 2,6 \\
\hline
\end{tabular}

Tabela 13b. Parâmetros estatísticos da distribuição granulométrica (phi) das amostras

\begin{tabular}{|c|c|c|c|c|c|c|c|c|}
\hline \multicolumn{7}{|c|}{ Parâmetros Estatísticos da Distribuição Granulométrica (phi) - Pearson } \\
\hline Amostra & $\begin{array}{c}\text { Diâmetro } \\
\text { Médio }\end{array}$ & $\begin{array}{c}\text { Desvio } \\
\text { Padrão }\end{array}$ & Assimetria & Curtose & $\begin{array}{c}\text { Diâmetro } \\
\text { Médio }\end{array}$ & Desvio Padrão & Assimetria & Curtose \\
\hline CA S 1 & 2,48 & 2,47 & 1,59 & 4,90 & 1,50 & 0,99 & 0,06 & 2,52 \\
\hline CA S 2 & 4,16 & 3,24 & 0,38 & 1,81 & 1,48 & 1,07 & 0,36 & 2,59 \\
\hline CA S 3 & 3,05 & 2,34 & 1,16 & 4,25 & 1,99 & 1,16 & $-0,24$ & 2,18 \\
\hline CA S 4 & 3,18 & 2,98 & 1,03 & 2,91 & 1,45 & 0,99 & 0,32 & 2,72 \\
\hline CA S 5 & 4,50 & 2,74 & 0,25 & 2,30 & 2,02 & 1,23 & $-0,01$ & 1,83 \\
\hline PB SJ 2 & 2,98 & 1,89 & 1,82 & 6,11 & 2,25 & 0,73 & 0,19 & 2,43 \\
\hline CA L 1 & 4,13 & 2,49 & 0,62 & 2,64 & 2,35 & 1,05 & $-0,34$ & 2,24 \\
\hline CA L 2 & 3,42 & 2,36 & 0,99 & 3,60 & 2,15 & 1,09 & $-0,15$ & 2,04 \\
\hline CA L 3 & 3,53 & 2,53 & 1,11 & 3,62 & 2,18 & 1,02 & $-0,23$ & 2,34 \\
\hline CA L 4 & 3,74 & 2,65 & 0,67 & 2,71 & 1,89 & 1,11 & 0,03 & 2,16 \\
\hline CA L 5 & 4,11 & 2,96 & 0,58 & 2,21 & 1,88 & 1,07 & 0,20 & 2,08 \\
\hline PB 2 SJ & 2,36 & 2,10 & 1,42 & 4,78 & 1,55 & 1,07 & 0,65 & 2,57 \\
\hline
\end{tabular}




\subsection{2 - Análise Química dos Sedimentos de Fundo}

A tabela 14 expressa os resultados da análise química dos sedimentos de fundo da porção SW do Reservatório de Biritiba-Mirim (SP) em área protegida por área preservada. Os valores destacados em negrito e sublinhados aparecem mais elevados, apesar de não terem ultrapassado os limites de detecção do equipamento utilizado.

Tabela 14. Valores da análise química dos sedimentos de fundo da porção $\mathrm{SW}$ do Reservatório de Biritiba-Mirim (SP) em área protegida por mata preservada

\begin{tabular}{|c|c|c|c|c|c|}
\hline Amostra & CAL1 & CAL2 & CAL3 & CAL4 & CAL5 \\
\hline$\underline{\mathrm{P}}_{2} \underline{\mathrm{O}}_{5}(\mathrm{ppm})$ & $\underline{0,056}$ & $\underline{0,033}$ & $\underline{0,052}$ & $\underline{0,056}$ & $\underline{0,122}$ \\
\hline$\underline{\mathrm{SO}_{3}}(\mathrm{ppm})$ & $\underline{0,015}$ & $\underline{0,015}$ & $\underline{0,034}$ & $\underline{0,025}$ & $\underline{0,084}$ \\
\hline$\underline{\mathrm{K}_{2}} \mathrm{O}(\mathrm{ppm})$ & $\underline{3,31}$ & $\underline{0,190}$ & $\underline{1,89}$ & $\underline{3,26}$ & $\underline{1,79}$ \\
\hline$\underline{\mathrm{MnO}}(\mathrm{ppm})$ & $\underline{0,017}$ & $\underline{0,009}$ & $\underline{0,015}$ & $<0,001$ & 0,022 \\
\hline
\end{tabular}

Estão indicados os valores de elementos cujos resultados encontram-se acima dos limites de detecção do equipamento utilizado para essas análises os resultados para $\mathrm{Cu}, \mathrm{Zn}, \mathrm{Cr}, \mathrm{Ni}, \mathrm{Br}, \mathrm{Ba}$ e Ce ficaram abaixo do limite de detecção do equipamento

A tabela 15 expressa os resultados da análise química dos sedimentos de fundo da porção SW do Reservatório de Biritiba-Mirim (SP) em área próxima ao reservatório com atividade agrícola. Os valores destacados em negrito e sublinhados aparecem mais elevados, apesar de não terem ultrapassado os limites de detecção do equipamento utilizado.

Tabela 15. Valores da análise química dos sedimentos de fundo da porção SW do Reservatório de Biritiba-Mirim(SP) em área próxima ao reservatório com atividade agrícola

\begin{tabular}{|c|c|c|c|c|c|}
\hline Amostra & CAS1 & CAS2 & CAS3 & CAS4 & CAS5 \\
\hline $\mathrm{P}_{2} \mathrm{O}_{5}(\mathrm{ppm})$ & $\mathrm{ND}$ & 0,018 & 0,059 & 0,015 & 0,045 \\
\hline $\mathrm{SO}_{3}(\mathrm{ppm})$ & $\mathrm{ND}$ & 0,010 & $<0,001$ & 0,011 & 0,018 \\
\hline $\mathrm{K}_{2} \mathrm{O}(\%)$ & $\mathrm{ND}$ & 0,184 & 2,50 & 0,192 & 0,211 \\
\hline
\end{tabular}

Estão indicados os valores de elementos cujos resultados encontram-se acima dos limites de detecção do equipamento utilizado para essas análises os resultados para $\mathrm{Mn}, \mathrm{Cu}, \mathrm{Zn}, \mathrm{Cr}, \mathrm{Ni}, \mathrm{Br}, \mathrm{Ba}$ e $\mathrm{Ce}$ ficaram abaixo do limite de detecção do equipamento 
A tabela 16 exibe os resultados da análise química dos sedimentos de fundo da cabeceira do Ribeirão Biritiba-Mirim(SP), pontos brancos. Os valores destacados em negrito e sublinhados aparecem mais elevados, apesar de não terem ultrapassado os limites de detecção do equipamento utilizado.

Tabela 16. Valores da análise química dos sedimentos de fundo da cabeceira do Ribeirão Biritiba-Mirim(SP)

\begin{tabular}{|c|c|c|}
\hline Amostra & PBSM2 & PBSJ2 \\
\hline $\mathrm{P}_{2} \mathrm{O}_{5}(\mathrm{ppm})$ & 0,016 & 0,028 \\
\hline $\mathrm{SO}_{3}(\mathrm{ppm})$ & $<0,001$ & 0,013 \\
\hline $\left.\mathrm{K}_{2} \mathrm{O} \mathrm{ppm}\right)$ & 0,661 & 0,911 \\
\hline $\mathrm{CuO}(\mathrm{ppm})$ & 0,004 & $<0,001$ \\
\hline
\end{tabular}

Estão indicados os valores de elementos cujos resultados encontram-se acima dos limites de detecção do equipamento utilizado para essas análises os resultados para $\mathrm{Mn}, \mathrm{Zn}, \mathrm{Cr}, \mathrm{Ni}, \mathrm{Br}$, Ba e Ce ficaram abaixo do limite de detecção do equipamento

A Tabela 17 compara os valores orientadores de elementos químicos máximo permitidos para solo no Estado de São Paulo, segundo PEL/TEL, CETESB 2005, CETESB 2014 e a Resolução do CONAMA 344/2004.

Tabela 17. Comparação entre valores máximo permitidos de elementos químicos em sedimentos

\begin{tabular}{|c|c|c|c|c|}
\hline $\begin{array}{c}\text { Elementos } \\
(\mathrm{mg} . \mathrm{Kg})\end{array}$ & $\begin{array}{c}\text { PEL/TEL } \\
(\mathrm{mg} . \mathrm{Kg})\end{array}$ & $\begin{array}{c}\text { CETESB } \\
\mathbf{2 0 0 5}(\mathrm{mg} . \mathrm{Kg})\end{array}$ & $\begin{array}{c}\text { CETESB } \\
\mathbf{2 0 1 4}(\mathrm{mg} . \mathrm{Kg})\end{array}$ & $\begin{array}{c}\text { CONAMA } \\
\mathbf{3 4 4 / 2 0 0 4} \\
(\mathrm{mg} . \mathrm{Kg})\end{array}$ \\
\hline $\mathrm{P}_{2} \mathrm{O}_{5}$ & $\mathrm{ND}$ & $\mathrm{ND}$ & $\mathrm{ND}$ & 2000 \\
\hline $\mathrm{SO}_{3}$ & $\mathrm{ND}$ & $\mathrm{ND}$ & $\mathrm{ND}$ & $\mathrm{ND}$ \\
\hline $\mathrm{K}_{2} \mathrm{O}$ & $\mathrm{ND}$ & $\mathrm{ND}$ & $\mathrm{ND}$ & $\mathrm{ND}$ \\
\hline $\mathrm{MnO}$ & $\mathrm{ND}$ & $\mathrm{ND}$ & $\mathrm{ND}$ & $\mathrm{ND}$ \\
\hline $\mathrm{CuO}$ & $<35,7$ & 35 & 35 & 35,7 \\
\hline
\end{tabular}

* Valor alerta: Valor acima do qual representa possibilidade de causar prejuízo ao ambiente na área de disposição.

* ND: as normativas em questão nada declaram sobre os elementos químicos presentes na tabela.

Fonte: CETESB 2005, CETESB, 2011, Cetesb 2014 e CONAMA 344/2004.

Segundo as quatro normativas avaliadas: PEL/TEL, CETESB 2005 e 2014 e CONAMA 344/2004, os valores dos elementos químicos P, S, K e Mn em sedimento de fundo não são contemplados pelo PEL/TEL e CETESB 2005, assim como os valores dos elementos S, K e Mn pelo CONAMA 344/2004.

Observa-se que o elemento $\mathrm{CuO}$ apresenta valores equivalentes em todas as quatro normativas analisados nessa dissertação. No entanto, o elemento $\mathrm{P}_{2} \mathrm{O}_{5}$ é 
relatado somente na resolução do CONAMA 344/2004, que indica o valor máximo permitido em $2000 \mathrm{mg} . \mathrm{Kg}$.

O diagrama da figura 27 apresenta os elementos encontrados nas amostras retiradas da área com mata preservada. Observa-se que o fósforo e o enxofre, representados respectivamente pelas cores azul e vermelho, da amostra CAL1 a amostra CAL5, aumentam a quantidade. Eles são elementos solúveis e se deslocam com a água, sendo posteriormente depositados no sedimento de fundo. Comportamento que já não pode ser observado pelos elementos cobre e níquel, que apresentam aumento de sua concentração somente na amostra CAL4. Já o manganês exibe incremento em sua concentração nas amostras CAL1, CAL2, CAL3 e CAL5, mas aparece em pouca quantidade na amostra CAL4.

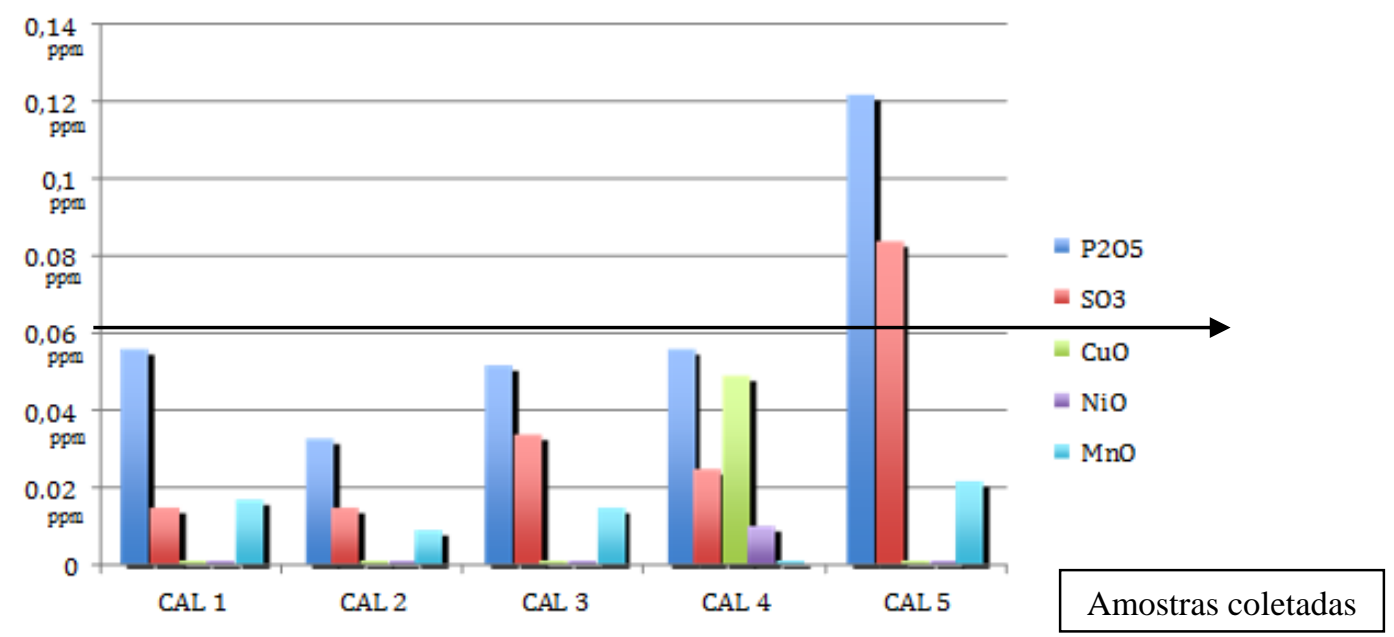

Figura 27 - Diagrama dos elementos químicos e suas quantidades relativas encontradas nas amostras retiradas da área do reservatório circundada por mata preservada. O eixo das ordenadas representa a concentração dos elementos químicos encontrados nas amostras CAL A seta no valor 0,06 indica o valor de referência para as amostras analisadas destacando que na CAL5 os valores ultrapassam essa linha de refência.

O diagrama representado na figura 28 representa os elementos encontrados nas amostras retiradas da área sob influência de atividade agrícola. Observa-se que o fósforo, enxofre e níquel não apresentam comportamento de acréscimo de suas concentrações, são valores anômalos e individuais. Contudo, o cobre aparece em todas as amostras, elemento esse frequentemente presente em micronutrientes utilizados na agricultura. 


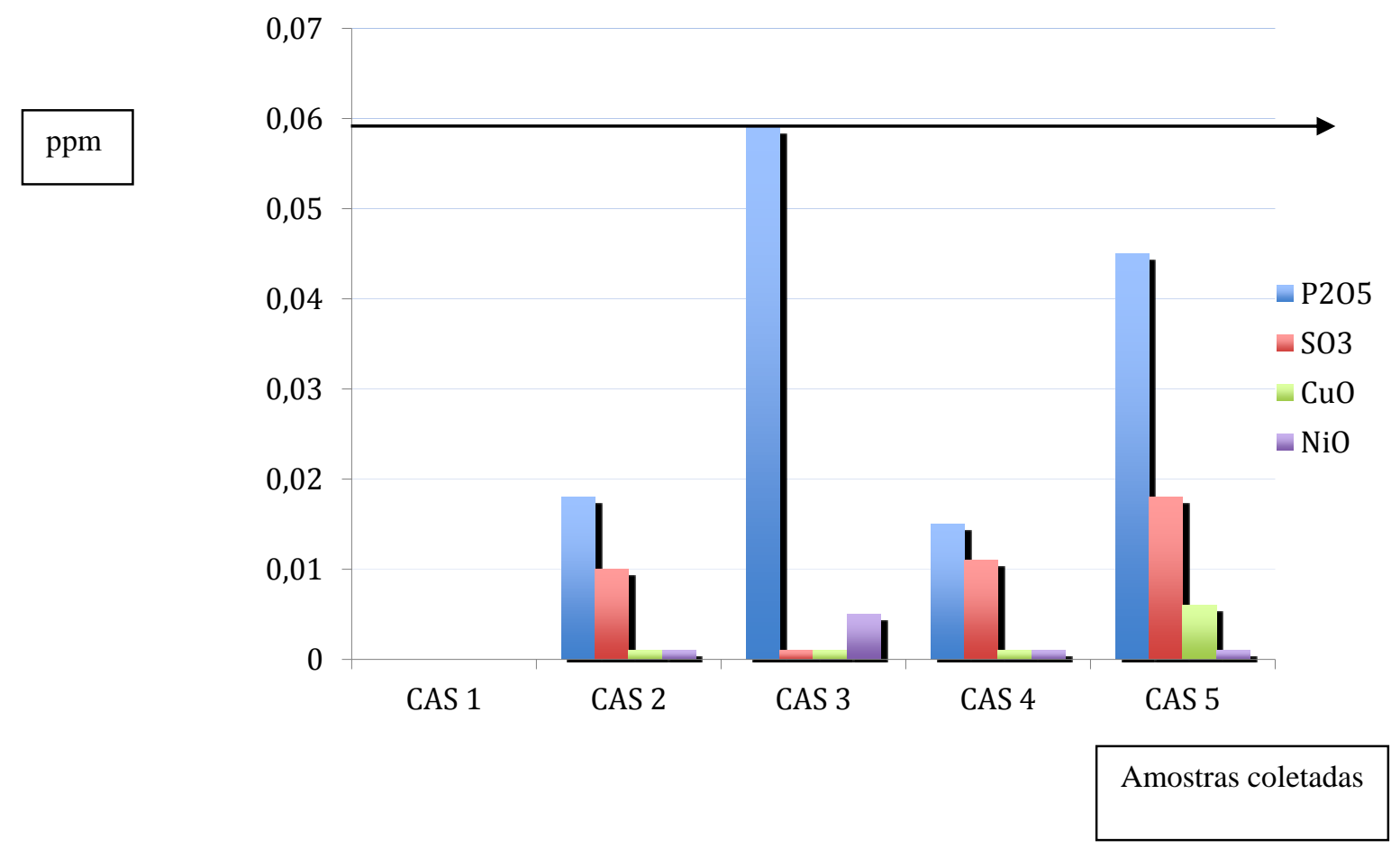

Figura 28 - Diagrama dos elementos químicos e suas quantidades encontradas nas amostras retiradas da área do reservatório circundada por atividade agrícola. O eixo das ordenadas representa a concentração dos elementos químicos encontrados nas amostras CAS. A seta no valor 0,06 indica o valor de referência para as amostras analisadas destacando que na CAL5 os valores ultrapassam essa linha de refência

A figura 29 mostra a presença de fósforo, enxofre e cobre nas duas amostras retiradas do ponto branco, localizados na cabeceira do rio Biritiba-Mirim. Observa-se concentrações crescentes nos valores de fósforo e enxofre, mas diminuição nas concentrações do cobre. 


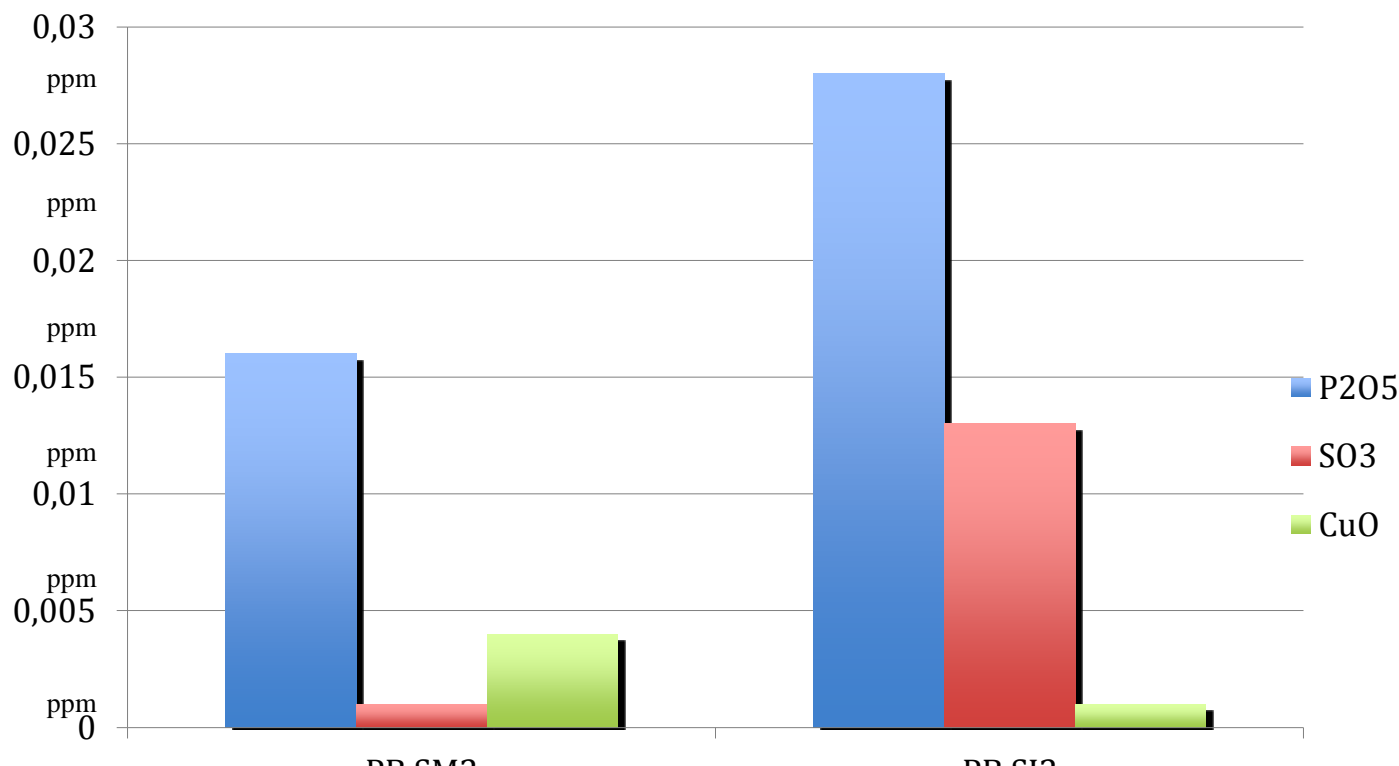

PB SM2

PB SJ2

Figura 29 - Diagrama que representa os elementos químicos e suas quantidades encontradas nas amostras retiradas do ponto considerado de referência. $\mathrm{O}$ eixo das ordenadas representa a concentração dos elementos químicos encontrados nas amostras referência.

\subsection{3 - Análise Química da Água}

Para análise e determinação química da água as amostras coletadas no local de estudo foram encaminhadas para o laboratório de química da SABESP como mencionado em item anterior. Houve análise dos seguintes elementos químicos: Ag, Al, As, Ba, Ca, Cd, Cr, Cu, Fe, Mg, Mn, Na, Ni, Pb, Sb, Se, Zn e Fósforo. As tabelas 22, 23 e 24 mostram somente os valores acima dos limites de detecção do aparelhos.

Tabela 18. Valores dos parâmetros químicos da água analisados em laboratório para o Reservatório de Biritiba-Mirim (SP) nas áreas com mata preservada. Os valores apresentados são apenas os obtidos acima dos limites de detecção do aparelho

\begin{tabular}{|c|c|c|c|c|c|c|c|c|}
\hline Amostra & $\begin{array}{c}\mathbf{A l} \\
\mathrm{mg} / \mathrm{L}\end{array}$ & $\mathbf{C a} \mathrm{mg} / \mathrm{L}$ & $\mathbf{F e} \mathrm{mg} / \mathrm{L}$ & $\mathbf{M n} \mathrm{mg} / \mathrm{L}$ & $\mathbf{M g} \mathrm{mg} / \mathrm{L}$ & $\begin{array}{c}\mathbf{N a} \\
\mathrm{mg} / \mathrm{L}\end{array}$ & $\begin{array}{c}\mathbf{Z n} \\
\mathrm{mg} / \mathrm{L}\end{array}$ & $\mathbf{P} \mathrm{mg} / \mathrm{L}$ \\
\hline CAL 1 & 0,13 & 1,09 & 0,34 & $<0,02$ & 0,42 & 1,26 & 0,18 & 0,03 \\
\hline CAL 2 & 0,13 & 1,32 & 0,31 & $<0,02$ & 0,45 & 2,64 & 0,12 & 0,21 \\
\hline CAL 3 & 0,10 & 1,15 & 0,39 & $<0,02$ & 0,41 & 1,16 & 0,05 & 0,09 \\
\hline CAL 4 & 0,15 & 1,22 & 0,25 & $<0,02$ & 0,39 & 2,14 & 0,14 & 0,05 \\
\hline CAL 5 & 0,11 & 1,44 & 0,26 & $<0,02$ & 0,40 & 1,71 & 0,15 & 0,06 \\
\hline
\end{tabular}


Tabela 19 - Valores dos parâmetros químicos da água analisados em laboratório para o Reservatório de Biritiba-Mirim (SP) em áreas sob influência de atividade agrícola. Os valores apresentados são apenas os obtidos acima dos limites de detecção do aparelho

\begin{tabular}{|c|c|c|c|c|c|c|c|c|c|}
\hline Amostra & $\begin{array}{c}\mathbf{A l} \\
\mathrm{mg} / \mathrm{L}\end{array}$ & $\begin{array}{c}\mathbf{C a} \\
\mathrm{mg} / \mathrm{L}\end{array}$ & $\begin{array}{c}\mathbf{F e} \\
\mathrm{mg} / \mathrm{L}\end{array}$ & $\begin{array}{c}\mathbf{M g} \\
\mathrm{mg} / \mathrm{L}\end{array}$ & $\begin{array}{c}\mathbf{M n} \\
\mathrm{mg} / \mathrm{L}\end{array}$ & $\begin{array}{c}\mathbf{N a} \\
\mathrm{mg} / \mathrm{L}\end{array}$ & $\begin{array}{c}\mathbf{P b} \\
\mathrm{mg} / \mathrm{L}\end{array}$ & $\begin{array}{c}\mathbf{Z n} \\
\mathrm{mg} / \mathrm{L}\end{array}$ & $\mathbf{P} \mathrm{mg} / \mathrm{L}$ \\
\hline CAS 1 & 0,24 & 2,02 & 0,45 & 0,75 & $<0,02$ & 2,47 & $<0,01$ & 0,08 & $\mathrm{ND}$ \\
\hline CAS 2 & 0,11 & 1,16 & 0,35 & 0,44 & $<0,02$ & 1,92 & 0,010 & 0,10 & $\mathrm{ND}$ \\
\hline CAS 3 & 4,88 & 2,50 & 18,19 & 0,71 & 0,70 & 1,89 & 0,01 & 0,06 & $\mathrm{ND}$ \\
\hline CAS 4 & 0,08 & 1,50 & 0,36 & 0,41 & $<0,02$ & 1,51 & $<0,01$ & 0,06 & $\mathrm{ND}$ \\
\hline CAS 5 & 0,17 & 3,14 & 0,32 & 0,71 & $<0,02$ & 1,69 & $<0,01$ & 0,23 & $\mathrm{ND}$ \\
\hline
\end{tabular}

Tabela 20 - Valores dos parâmetros químicos da água analisados em laboratório para o Reservatório de Biritiba-Mirim (SP) no ponto considerado de referência. Os valores apresentados são apenas os obtidos acima dos limites de detecção do aparelho

\begin{tabular}{|l|c|c|c|c|c|c|c|c|c|}
\hline Amostra & $\begin{array}{c}\mathbf{A l} \\
\mathrm{mg} / \mathrm{L}\end{array}$ & $\begin{array}{c}\mathbf{C a} \\
\mathrm{mg} / \mathrm{L}\end{array}$ & $\begin{array}{c}\mathbf{F e} \\
\mathrm{mg} / \mathrm{L}\end{array}$ & $\begin{array}{c}\mathbf{M g} \\
\mathrm{mg} / \mathrm{L}\end{array}$ & $\begin{array}{c}\mathbf{M n} \\
\mathrm{mg} / \mathrm{L}\end{array}$ & $\begin{array}{c}\mathbf{N a} \\
\mathrm{mg} / \mathrm{L}\end{array}$ & $\begin{array}{c}\mathbf{P b} \\
\mathrm{mg} / \mathrm{L}\end{array}$ & $\begin{array}{c}\mathbf{Z n} \\
\mathrm{mg} / \mathrm{L}\end{array}$ & $\mathbf{P} \mathrm{mg} / \mathrm{L}$ \\
\hline PBSM2 & 0,35 & 0,75 & 0,54 & 0,35 & 0,05 & 2,12 & $<0,01$ & 0,14 & 0,44 \\
& & & & & & & & & \\
\hline PBSJ2 & 0,17 & 0,56 & 0,7 & 0,31 & 0,024 & 1,99 & 0,01 & 0,25 & 0,13 \\
\hline
\end{tabular}

A Tabela 18 exibe os valores obtidos das amostras localizadas nos pontos da área com mata nativa. A tabela 19 contém os valores das amostras da área com atividade agrícola e a tabela 20, os valores das amostras coletadas na cabeceira do rio Biritiba, consideradas valores de referência, que também são utilizados pela SABESP como controle da água de recarga do reservatório.

Os resultados apresentados na tabela 18 demonstram que não há alterações nos valores dos parâmetros físico-químicos para o Reservatório de Biritiba-Mirim (SP) nas áreas com mata nativa, mas baseando-se nos valores máximos dos parâmetros inorgânicos da resolução 357/2005 do CONAMA, classe 1, observa-se não enquadramento de algumas amostras da área com atividade agrícola, assim como em amostras coletadas nos pontos de referência. 
Tabela 21. Comparação entre os valores obtidos da análise química da água das amostras analisadas e coletadas no reservatório com os valores máximos dos parâmetros das normativas em questão.

\begin{tabular}{|c|c|c|c|c|c|}
\hline Amostra & $\begin{array}{l}\text { Elementos } \\
\text { Químicos }\end{array}$ & $\begin{array}{l}\text { Parâmetros } \\
\text { químicos } \\
\text { (valores } \\
\text { alterados) }\end{array}$ & $\begin{array}{c}\text { CONAMA } \\
\text { 357/2005 } \\
\text { Classe } 1\end{array}$ & $\begin{array}{c}\text { MS Portaria } \\
\mathbf{N}^{\circ} \mathbf{2 9 1 4} \\
(\mathbf{2 0 1 1})\end{array}$ & $\begin{array}{c}\text { MS Portaria } \\
\mathbf{N}^{\circ} 045 \\
(\mathbf{2 0 1 4})\end{array}$ \\
\hline \multirow{2}{*}{ CAS1 } & $\mathrm{Al}$ & $0,238 \mathrm{mg} / \mathrm{L}$ & $0,10 \mathrm{mg} / \mathrm{L}$ & $0,2 \mathrm{mg} / \mathrm{L}$ & ND \\
\hline & $\mathrm{Fe}$ & $0,450 \mathrm{mg} / \mathrm{L}$ & $0,30 \mathrm{mg} / \mathrm{L}$ & $0,3 \mathrm{mg} / \mathrm{L}$ & ND \\
\hline \multirow{3}{*}{ CAS3 } & $\mathrm{Al}$ & $4,883 \mathrm{mg} / \mathrm{L}$ & $0,10 \mathrm{mg} / \mathrm{L}$ & ND & ND \\
\hline & $\mathrm{Fe}$ & $\begin{array}{c}18,190 \mathrm{mg} / \\
\mathrm{L}\end{array}$ & $0,30 \mathrm{mg} / \mathrm{L}$ & ND & ND \\
\hline & $\mathrm{Mn}$ & $0,700 \mathrm{mg} / \mathrm{L}$ & $0,10 \mathrm{mg} / \mathrm{L}$ & ND & ND \\
\hline CAS5 & $\mathrm{Zn}$ & $0,228 \mathrm{mg} / \mathrm{L}$ & $0,18 \mathrm{mg} / \mathrm{L}$ & $5 \mathrm{mg} / \mathrm{L}$ & $1,8 \mathrm{mg} / \mathrm{L}$ \\
\hline \multirow{2}{*}{ PBSM2 } & $\mathrm{Al}$ & $0,352 \mathrm{mg} / \mathrm{L}$ & $0,10 \mathrm{mg} / \mathrm{L}$ & $0,2 \mathrm{mg} / \mathrm{L}$ & ND \\
\hline & $\mathrm{Fe}$ & $0,537 \mathrm{mg} / \mathrm{L}$ & $0,30 \mathrm{mg} / \mathrm{L}$ & $0,3 \mathrm{mg} / \mathrm{L}$ & ND \\
\hline \multirow{2}{*}{ PBSJ2 } & $\mathrm{Fe}$ & $0,760 \mathrm{mg} / \mathrm{L}$ & $0,30 \mathrm{mg} / \mathrm{L}$ & $0,3 \mathrm{mg} / \mathrm{L}$ & ND \\
\hline & $\mathrm{Zn}$ & $0,252 \mathrm{mg} / \mathrm{L}$ & $0,18 \mathrm{mg} / \mathrm{L}$ & $5,0 \mathrm{mg} / \mathrm{L}$ & $1,8 \mathrm{mg} / \mathrm{L}$ \\
\hline
\end{tabular}

Fonte: Resolução CONAMA 357/2005, MS PORTARIA No 2914 e CETESB 045/2014 
Como observado na tabela 21, identifica-se que os elementos $\mathrm{Al}, \mathrm{Fe}, \mathrm{Mn}$ e $\mathrm{Zn}$ apresentam concentrações, em algumas amostras, acima do permitido pela resolução 357/2005 do CONAMA, classe 1 e CETESB 2014. Contudo, apresentam-se dentro da normalidade segundo a Portaria No 2914/2011 do Ministério da Saúde.

A amostra CAS 1 apresentou valor do parâmetro inorgânico Alumínio em 0,238 mg/L e de Ferro: 0,450 mg/L, sendo que na resolução 357/2005 do CONAMA, classe 1, os valores máximos permitidos nas águas de classe 1 são, respectivamente, $\mathrm{Al}$ - 0,1 $\mathrm{mg} / \mathrm{L}$ e $\mathrm{Fe}-0,3 \mathrm{mg} / \mathrm{L}$. Porém, para a Portaria No 2914 do MS, a amostra CAS 1 pode ser considerada dentro dos padrões de normalidade quanto ao parâmetro Al, pois consta em aproximadamente $0,2 \mathrm{mg} / \mathrm{L}$. Valor máximo permitido por esses dois órgãos estaduais.

Outras alterações que foram possíveis de serem observadas relacionam-se com os valores da amostra CAS 3 na qual, o elemento Alumínio está em quantidade de 4,883 mg/L, o Ferro 18,19 mg/L e o Manganês 0,700 mg/L. Ambos os três acima dos valores permitidos pelas três legislações analisadas nessa dissertação.

A amostra CAS 5 apresentou 0,228 mg/L de Zinco. Segundo o CONAMA 357/2005, está acima do permitido: 0,18 mg/L. Porém, para a Portaria No 2914 do MS está dentro da normalidade, já que ambas permitem o valor máximo de $5 \mathrm{mg} / \mathrm{L}$.

A amostra PBSM2, referente a cabeceira do rio Biritiba, exibe o valor de 0,352 mg/L para o Alumínio e 0,537 mg/L para o Ferro. Segundo legislações analisadas, os valores estão acima dos permitidos.

O ponto PBSJ2 tem alteração no parâmetro químico Ferro em 0,760 mg/L e 0,252 $\mathrm{mg} / \mathrm{L}$ de Zinco. O valor referente ao parâmetro Ferro está dentro da normalidade segundo a resolução 357/2005 do CONAMA, Portaria No 045 da CETESB 2014 e Portaria No 2914 do MS. Contudo, o valor permitido por esses órgãos são contraditórios quanto ao Zinco porque para o CONAMA 357/2005 há alteração, já que permite até $0,18 \mathrm{mg} / \mathrm{L}$, mas para a Portaria No 2914 do MS está dentro dos padrões normais por permitirem até $5 \mathrm{mg} / \mathrm{L}$. 


\section{4 - Análise do Uso e Ocupação do Solo por Sensoriamento Remoto}

A etapa inicial da avaliação dos resultados envolveu, primeiramente, a análise das imagens, após a realização da composição colorida, nas quais foram empregados Red-banda 2, Green - Banda 4 e Blue - banda 5.

Como pode ser observado na figura 30, que se refere ao ano de 1990 da esquerda para a direita, os reservatórios estão representados em preto, Taiaçupeba, que foi construído em 1976, Jundiaí, em 1989 e o último, Ponte Nova, 1971.

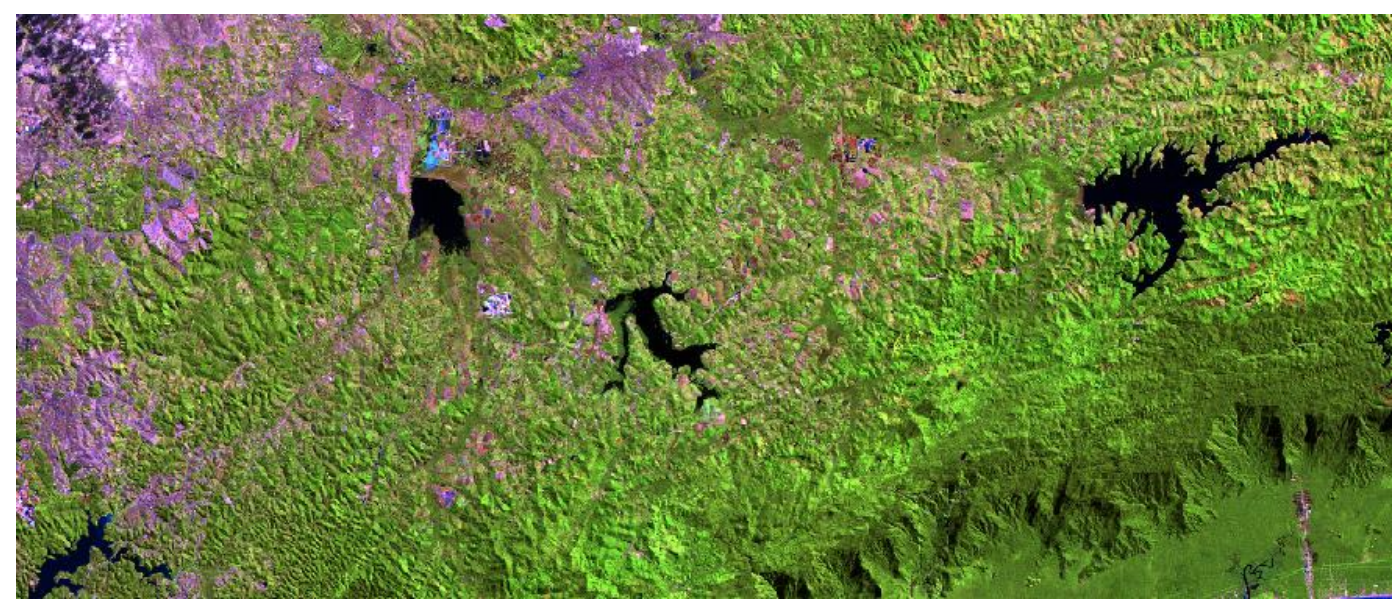

Figura 30. Imagem obtida por sensoriamento remoto através da técnica de composição colorida da Bacia Hidrográfica do Alto Tietê, ano de 1990.

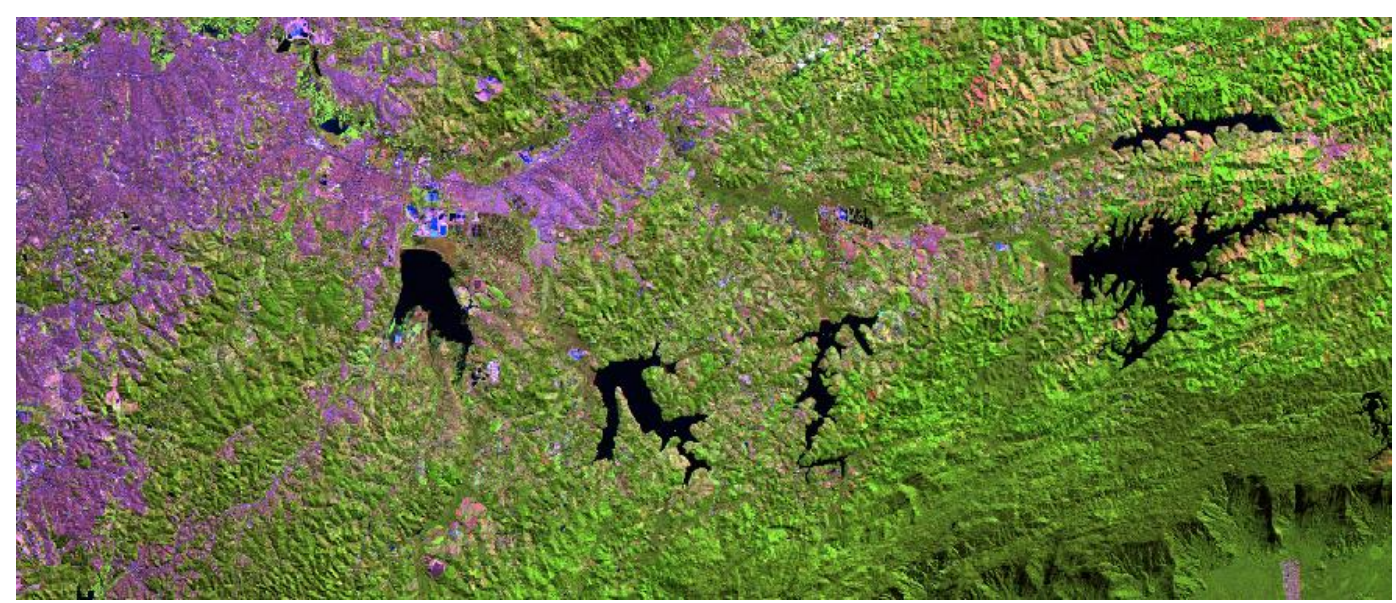

Figura 31. Imagem obtida por sensoriamento remoto através da técnica de composição colorida da Bacia Hidrográfica do Alto Tietê, ano de 2011

$\mathrm{Na}$ figura 30, a imagem correspondente ao ano de 2011, exibe os cinco reservatórios que compõem a Bacia Hidrográfica do alto Tietê. Da esquerda para a direita, estão os reservatórios de Taiaçubepa, Jundiaí, Biritiba-Mirim, Ponte Nova e o último, Paraitinga. Quando se compara as duas imagens, observa-se também que os reservatórios presentes na figura 30 ainda não apresentavam-se totalmente cheios de água, como é visto na figura 31. 
Esta diferença de imagens se dá pelo fato de os reservatórios de BiritibaMirim e Paraitinga terem sido construídos após 1990, quando foi coletada a primeira imagem da região pelo satélite LANDSAT 5. Segundo dados do DAEE, Biritiba-Mirim foi concluído no ano de 2001 e Paraitinga no ano de 2003.

A figura 32 mostra a digitalização dos vetores dos reservatórios que possibilita a obtenção do conhecimento da área de cada reservatório da bacia hidrográfica do Alto Tietê.

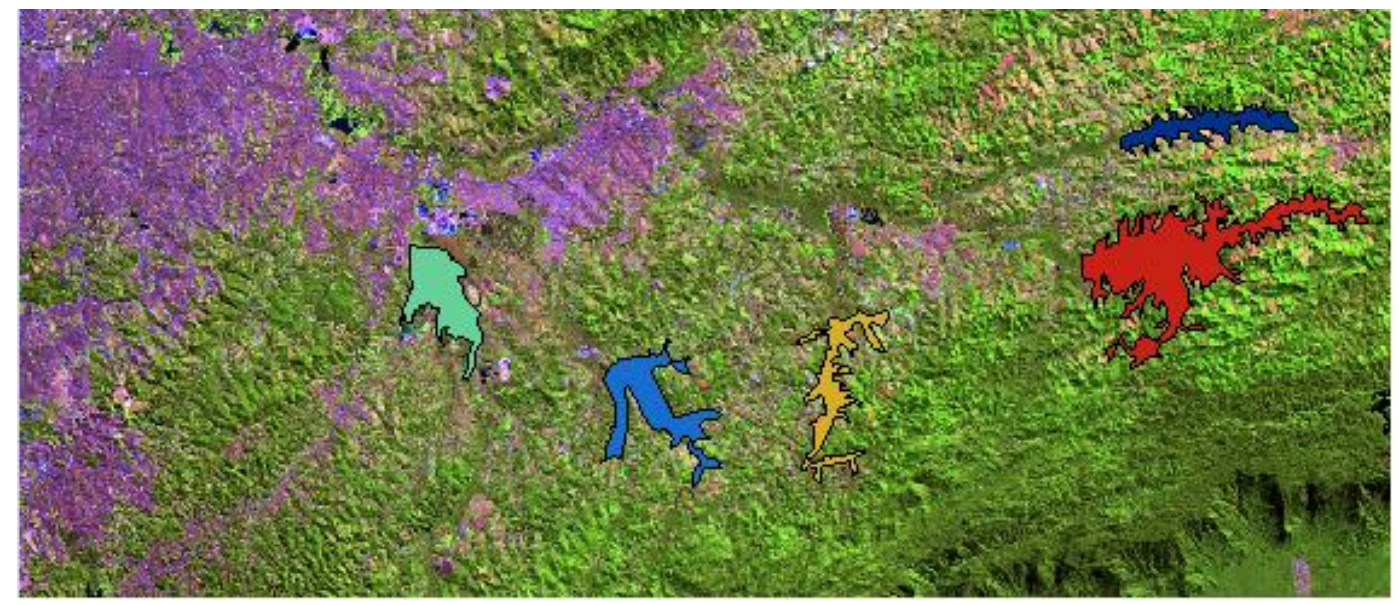

Figura 32. Representação da digitalização dos reservatórios da Bacia Hidrográfica do Alto Tietê

Após criar as amostras para treinamento do algoritmo de classificação, foi solicitado ao programa o cálculo quantitativo de cada classe, como seguem as figuras 33 e 34 . Os contornos em preto mostram qual será a área preenchida de água de cada reservatório.

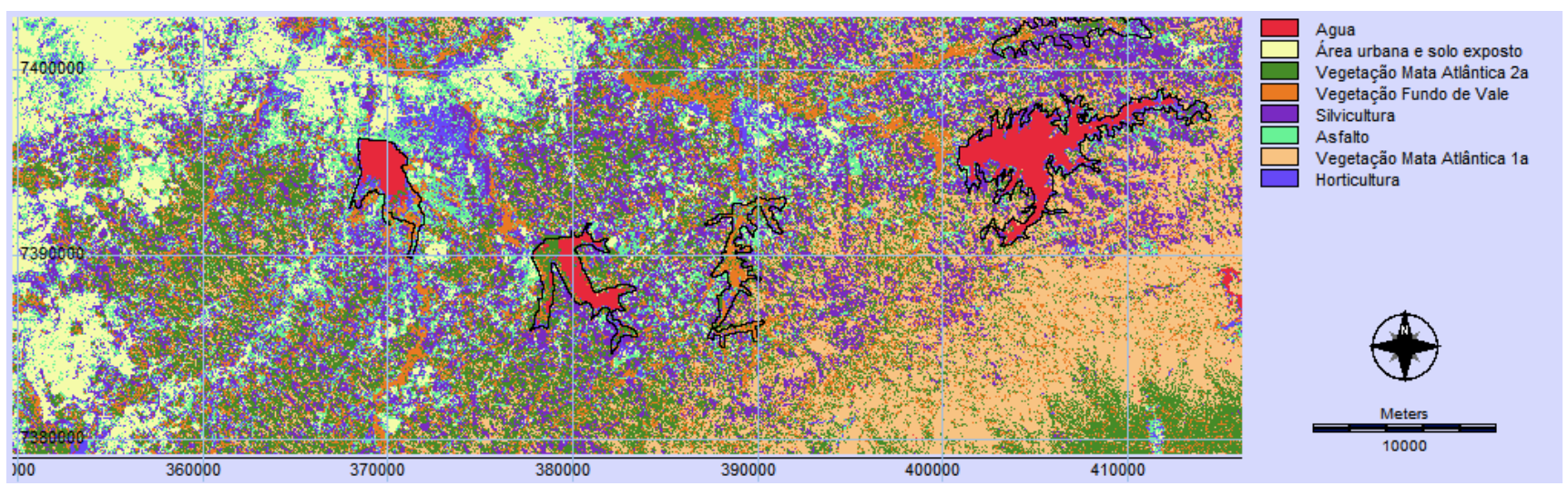

Figura 33. Classificação supervisionada da Bacia hidrográfica do Alto Tietê, ano de 1990. 


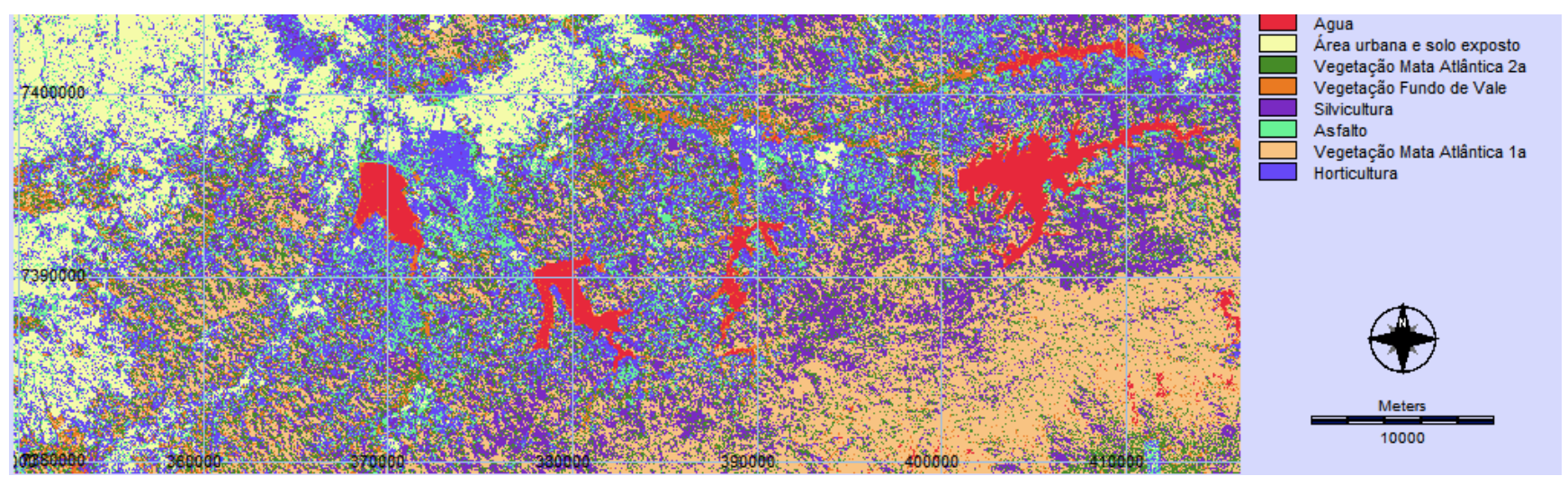

Figura 34. Classificação supervisionada da Bacia Hidrográfica do Alto Tietê, ano de 2011.

$\mathrm{Na}$ legenda das figuras 33 e 34 as diferentes classes foram assim delimitadas: a área urbana e solo exposto consiste na inclusão de todas as áreas urbanizadas, favela, loteamento, chácara, indústria, equipamento urbano, aterro sanitário, lixão e movimento de terra. A classe asfalto: inclui todas as ruas, avenidas e rodovias, enquanto a água envolve todas as drenagens superficiais como rios, lagos, reservatórios, oceanos e mares; classe Mata Atlântica secundária contempla áreas de reflorestamento e florestas descaracterizadas por exploração madeireira e a classe Mata Atlântica primária representa todas as formações florestais nativas, árvores altas e grossas. Finalmente a classe horticultura inclui todas as áreas com atividade agrícola; silvicultura florestas de Pinus $s p$ e eucaliptos, e vegetação de fundo de vale (rasteira).

Pode-se observar que a imagem de 2011 exibe uma diminuição da área urbana e solo exposto, em amarelo, ao mesmo tempo em que apresenta considerável crescimento da atividade de horticultura, representada pela cor azul. Também é possível observa os cinco reservatórios da Bacia Hidrográfica do Alto Tietê, em vermelho, todos preenchidos de água, diferentemente do que mostra a imagem de 1990. Após o cálculo quantitativo das classes de cada uma das imagens obtem-se uma tabela que compara os hectares de cada amostra do anos de 1990 e de 2011 (Tabela 22). 
Tabela 22. Tabela comparativa entre os valores em hectares de cada amostra, calculada em 1990 e em 2011

\begin{tabular}{|c|c|c|c|c|c|}
\hline Categoria & Classes de escolha & Área em ha 1990 & $\begin{array}{c}\text { Área em ha } \\
2011\end{array}$ & $\begin{array}{c}\text { Diferenças em } \\
\text { ha entre as } \\
\text { imagens de } \\
1990 \text { e } 2011\end{array}$ & $\begin{array}{c}\text { Diferença } \\
(\%)\end{array}$ \\
\hline 1 & Água & 3181,4 & 5267,4 & $+2.086,0$ & $+65,5 \%$ \\
\hline 2 & $\begin{array}{c}\text { Área urbana e solo } \\
\text { exposto }\end{array}$ & 20817,4 & 18920,7 & $-1.897,7$ & $-9,1 \%$ \\
\hline 3 & $\begin{array}{l}\text { Mata Atlântica } \\
\text { Secundária }\end{array}$ & 31851,1 & 23517,8 & $-8.333,4$ & $-26,1 \%$ \\
\hline 4 & $\begin{array}{c}\text { Vegetação } \\
\text { Fundo de Vale }\end{array}$ & 21623,3 & 8766,5 & $-6.603,1$ & $-30,5 \%$ \\
\hline 5 & Silvicultura & 28729,7 & 25391,3 & $-3.338,4$ & $-11,6 \%$ \\
\hline 6 & Asfalto & 18789,1 & 20026,7 & $+1.237,63$ & $+6,6 \%$ \\
\hline 7 & $\begin{array}{l}\text { Vegetação Mata } \\
\text { Atlântica Primária }\end{array}$ & 28056,2 & 26488,4 & $-1.567,8$ & $-5,6 \%$ \\
\hline 8 & Horticultura & 13958,4 & 32627,7 & $+18.669,3$ & $+133,7 \%$ \\
\hline
\end{tabular}

Comparando os dados obtidos pela classificação supervisionada das imagens de 1990 e 2011, percebe-se que a diminuição da área de silvicultura foi de $11,61 \%$ e o aumento na área de horticultura foi de $133,75 \%$. A área de asfalto e solo exposto aumentou 6,58\%, enquanto a área de Mata Atlântica primária apresentou uma diminuição de 5,58\% e a área de vegetação de fundo de vale e de mata atlântica secundária diminuíram 30,53\% e 26,16\%, respectivamente. 


\section{DISCUSSÃO.}

\subsection{Parâmetros Físico-Químicos da Água}

Os resultados evidenciam variações nos parâmetros físico-químicos da água do reservatório de Biritiba-Mirim. Neste sentido, tanto os pontos de coleta na área sob influência de atividade agrícola como na área com mata preservada demonstram valores de $\mathrm{pH}$ um pouco mais alcalino quando comparados aos valores obtidos nos pontos de referência, que se mostraram ácidos. Segundo Prado (2004) esse parâmetro, apesar de difícil análise, pode ser decisivo nas conclusões gerais, uma vez que revela elevadas concentrações de ácidos orgânicos quando estão em valor elevado. Von Sperling (2005) concorda com tal ponderação quando menciona que o pH se altera quando há despejo de matéria orgânica.

O parâmetro oxigênio dissolvido (OD) apresenta variação nos pontos da área sob influência de atividade agrícola, enquanto na área com mata preservada existem dois pontos dentro dos parâmetros. A diminuição deste parâmetro nas águas torna o meio anaeróbio, altera o pH devido a variação da quantidade de dióxido de carbono na água e pode indicar, segundo Sperling (2005), caracterização dos efeitos da poluição das águas por despejos orgânicos.

A quantidade de oxigênio dissolvido na água associa-se à temperatura e à pressão atmosférica. Deste modo, em temperaturas mais baixas, há maior quantidade de oxigênio dissolvido, situação coerente com os resultados apresentados, visto que o valor de OD elevado no ponto de referência relaciona-se à temperatura em torno de $14{ }^{\circ} \mathrm{C}$, cinco graus mais baixa que nas demais áreas. Isto porque em reservatórios ocorre estratificação térmica, caracterizada pela diferença de temperatura nas camadas, promovendo a propagação do calor (PRADO, 2004).

A Condutividade Elétrica (CE) apresentou-se menor no ponto de referência, na cabeceira do Rio Biritiba do que nos demais locais analisados. Valor elevado revela concentrações de poluentes, pois no meio aquático, a CE é dependente de outros fatores como a temperatura e o pH, mas também sofre influência direta da decomposição da matéria orgânica e fotossíntese, pois se associam à composição iônica da água (PRADO, 2004).

De acordo com Von Sperling (2005) a turbidez da água é dada pela quantidade de partículas em suspensão que contribuem para a poluição, pois medem a capacidade 
de dispersão da radiação, restringindo a ação de seres fotossintetizantes que reduzem a reposição de oxigênio. $\mathrm{Na}$ presente dissertação todas as áreas apresentaram conformidade com a legislação vigente, sendo importante ressaltar que o ponto de referência, na nascente do rio, apresentou valores muito baixos para turbidez, como era esperado.

O potencial de oxi-redução é controlado por diversos fatores presentes no meio aquático, como o tipo de sedimento, águas superficiais e/ou águas subterrâneas. $\mathrm{Na}$ presente dissertação, os resultados do potencial de oxirredução apresentaram valores que variam entre 225,3 a 281,7 ORP, não sendo estatisticamente significativas. Teixeira et al (1999) relatam que a distribuição desses processos de oxidação-redução antecipam o destino e o transporte dos contaminantes químicos em ambiente aquático.

\subsection{Granulometria de Sedimentos}

A análise granulométrica mostrou que as amostras CAS 2, CAS 4, CAS 5 e CAL 5 apresentaram em sua constituição, porcentagem elevada de argila e silte. Dessa forma, pode ser que a presença de elementos químicos no sedimento de fundo dessas amostras esteja associada com essa constituição argila/silte em seu sedimento, que possui maior capacidade de reter elementos químicos. Segundo CCN (1997) os depósitos aluviais encontrados nas drenagens do reservatório são compostos por camadas argilosas, ricas em material orgânico, areias inconsolidadas de granulometria variada e cascalhos.

As amostras CAL 1, CAL 2 e CAL 3 são constituídas por areia muito fina. Quanto mais finos são os sedimentos, maior é a capacidade de retenção de elementos químicos potencialmente poluentes. Nos três casos, observa-se comparando-se com as outras amostras que essas para os elementos $\mathrm{P}_{2} \mathrm{O}_{5}, \mathrm{SO}_{3}, \mathrm{~K}_{2} \mathrm{O}$ exibem maiores valores desse elementos. Esses elementos podem ser indicativos de fertilizantes empregados na agricultura da região. Já o $\mathrm{MnO}$ elevado pode ser proveniente tanto da constituição da rocha que compõe a geologia do local, como de aditivos agrícolas. Segundo Jesus et al, (2004) os sedimentos de fundo são considerados bons indicadores de espécies poluentes uma vez que apresentam alta capacidade de sorção. 


\subsection{Análise Química de Sedimentos de Fundo}

Os resultados da análise química de sedimentos de fundo evidenciam que as amostras retiradas da área com mata preservada estão mais enriquecidas pelos elementos químicos: $\mathrm{P}_{2} \mathrm{O}_{5}, \mathrm{SO} 3, \mathrm{~K} 2 \mathrm{O}, \mathrm{MnO}, \mathrm{CuO}, \mathrm{ZnO}$ e $\mathrm{PbO}$ do que a área com atividade agrícola próxima ao reservatório. Uma provável explicação é a existência de grandes proporções de macrófitas dentro do reservatório os quais são sabidamente absorvedores de elementos químicos inclusive metais, os quais migram de um local para outro no reservatório segundo as direções preferênciais dos ventos mais fortes (geralmente de sul para norte). Esses vegetais tem se mostrado eficientes na despoluição das águas já que apresentam raízes que podem fazer a retenção desses elementos químicos.

Cheruvelil e Soranno (2008) in Bottino et al 2013 relata que as atividades antrópicas são bons parâmetros para a presença de macrófitas, já que se tem registrado uma boa relação entre as atividades agrícolas e a presença de macrófitas emergentes. Para Lacoul e Freedman, 2006 in Bottino et al 2013 algumas espécies desses vegetais são tolerantes à poluição, principalmente os elementos provenientes de áreas agrícolas. Para o autor as atividades humanas (isto é, entrada de efluentes domésticos e industriais, o uso de fertilizantes e barragens de construção) tendem a favorecer abundantemente a produção de macrófitas em reservatórios.

Também é possível que o vento existente na região do reservatório, através da movimentação constante das águas, possa carregar os elementos químicos, ainda em suspensão, até a região das amostras retiradas da área com mata preservada, posteriormente depositando-se no sedimento de fundo.

Sousa (2015) analisou sedimentos de suspensão com auxílio de imagens de Microscopia eletrônica de Varredura e EDS do reservatório de Biritiba-Mirim, coletadas nos mesmos pontos de coleta das amostras CAS e CAL, realizadas nessa dissertação, e detectou também a presença de K provavelmente originário de parte das alterações intempéricas de rochas que circundam o reservatório.

Ainda expondo os resultados obtidos por Sousa (2015), a amostra CAS4 exibiu a presença de $\mathrm{Mn}$, que é um elemento químico muito frequente no Complexo Embú mas, também pode ser considerado material proveniente de aditivos agrícolas visto que esse elemento participa da formulação de agrotóxicos e de suplementos agrícolas. Também percebeu-se a presença de Mo e F, possivelmente elementos provindos de atividade agrícola. 
Há possibilidade de vínculo entre a presença dos elementos $\mathrm{P}_{2} \mathrm{O}_{5}, \mathrm{SO} 3$ e $\mathrm{CuO}$ encontrado, tanto em amostras coletadas na região com mata preservada como na região com atividade agrícola próxima ao reservatório, com os fertilizantes utilizados na agricultura da região, já que $\mathrm{P}_{2} \mathrm{O}_{5}$ é facilmente encontrado em adubos e os elementos $\mathrm{SO} 3$ e $\mathrm{CuO}$ são micronutrientes presentes em fertilizantes. Para Hortellani et al (2008) a poluição dos sedimentos de fundo está estreitamente ligada à poluição das águas e tem origem em fontes, como efluentes agrícolas. Eles ainda possibilitam o conhecimento das principais fontes de poluição dentro de um sistema aquático (JESUS et al, 2004).

A presença de determinados elementos químicos em amostras retiradas da área com mata preservada pode estar relacionada a proximidade da área com atividade agrícola próxima ao reservatório. Além disso, a direção e a intensidade do vento no Reservatório de Biritiba-Mirim (SP), possivelmente de Sul para Norte, empurra os aguapés e os poluentes até essa área.

Nas duas amostras retiradas do ponto branco esperava-se não encontrar os elementos químicos fósforo, enxofre e cobre. Porém, são pontos muito distantes dos locais estudados no reservatório de Biritiba-Mirim (amostras CAL e CAS), Esses elementos podem tanto ser provenientes da rocha que compõe o sedimento de fundo do Reservatório como estarem associados a atividade agrícola presente a montante dos pontos de coleta desses pontos brancos.

$\mathrm{Na}$ figura 35 a área de coleta dos pontos brancos encontram-se na região dominada por um ambiente fluvial (conforme indica o esquema teórico proposto por ESTEVES, 1998). Por outro lado todas as amostras CAL e CAS considerando a mesma proposta de Esteves (1998) sediam-se em meio com características lagunares. 


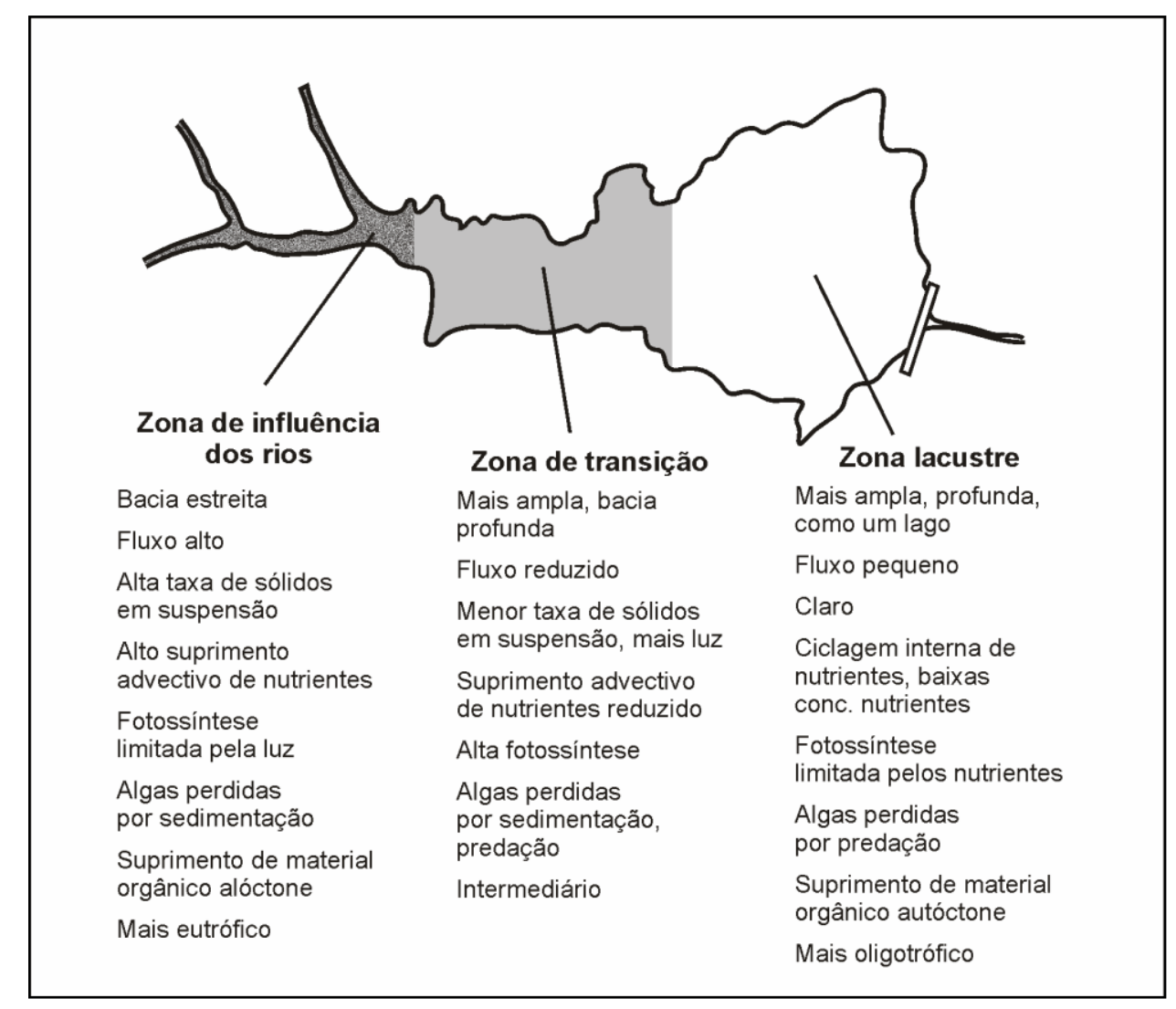

Figura 35 - Zonação longitudinal do reservatório.

Fonte: COOKE et al 2005

A característica lacustre do ambiente onde foram coletadas as amostras CAL e CAS talvez permita indicar que na área de mata preservada sejam mais enriquecidas por elementos químicos do que as amostras coletadas no ponto branco visto que esse encontra-se em domínio fluvial. Considerando que nesse meio a turbulência do meio aquoso permite um fluxo pequeno de água, fazendo com que haja maior concentração de nutrientes nesse local. De acordo com ESTEVES (1998), sistemas lacustres como os reservatórios representam bacias de sedimentação, com características específicas de ambientes deposicionais, podendo atingir níveis de contaminação bastante elevados em certos locais. Pode ser que a diferença do local de coleta das amostras CAL, CAS e ponto branco promova essa diferença de resultados.

\subsection{Análise Química da Água}

Os resultados também demonstram diferenças na análise química da água do reservatório de Biritiba-Mirim. Algumas amostras coletadas na área sob influência de atividade agrícola e no ponto de referência apresentaram-se distintas quanto a alguns 
elementos químicos referenciados na resolução do CONAMA 357/2005 e diferem dos pontos amostrados na área com mata preservada, que se enquadram nos parâmetros previstos.

A presença dos metais $\mathrm{Al}$ e $\mathrm{Fe}$ nas amostras de água coletadas na área sob influência de atividade agrícola, em concentração acima do valor permitido pela legislação brasileira, pode ser atribuída ao carreamento de partículas do solo contendo esses metais aderidos aos minerais constituintes, principalmente argilominerais. Porém, estes elementos também podem ter origem no escoamento de agroquímicos e fertilizantes, contendo os metais estudados (LIMA e SILVA, 2013).

A produção agrícola expressiva no trecho em que há destruição da mata ciliar próxima às margens do reservatório de Biritiba-Mirim pode facilitar o carreamento dos resíduos agrícolas e, consequentemente, aumentar as concentrações dos metais na água. Tal fato pode justificar a alta concentração de $\mathrm{Al}, \mathrm{Fe}$ e Mn nas amostras de água nos pontos CAS 1 e CAS 3, mas não faz relação com a presença destes mesmos metais nas amostras coletadas nos pontos PBSM2 e PBSJ2, considerados pontos de referência, localizados na cabeceira do rio.

Segundo Alloway et al. (1997) uma das mais importantes fontes de poluição por metais é proveniente das atividades agrícolas. A agricultura constitui uma das mais importantes fontes difusas de poluição por metais, onde tais elementos podem ser encontrados em:

- Fertilizantes: N, P, S, K (macronutrientes); $\mathrm{Cu}, \mathrm{Zn}, \mathrm{Mn}, \mathrm{Mo}, \mathrm{B}$ (micronutrientes)

- Defensivos agrícolas: $\mathrm{NH}_{4}{ }^{+}, \mathrm{Cl}, \mathrm{F}, \mathrm{K}, \mathrm{Cu}, \mathrm{As}, \mathrm{Hg}, \mathrm{Pb}, \mathrm{Mn}, \mathrm{Cd}, \mathrm{Zn}$

- Dejetos de criação intensiva de porcos e aves: $\mathrm{Cu}, \mathrm{As}, \mathrm{Zn}$

\subsection{Análise do Uso e Ocupação do Solo por Sensoriamento Remoto}

Silva (2003) relata que os reservatórios de captação de água passaram a apresentar significativas funções e por isso tornaram-se estratégicos para o desenvolvimento de atividades econômicas, como a agricultura. Isso pode ser visto com os resultados na análise das imagens de uso e ocupação do solo por sensoriamento remoto, pois mostraram que entre os anos de 1990 e 2011 houve uma diminuição considerável da área de silvicultura, de cerca de $11,61 \%$ e das áreas de Mata Atlântica e a área de vegetação de fundo de vale, respectivamente 
de $5,58 \%, 30,53 \%$ e $26,16 \%$. No entanto, a área de horticultura no entorno do reservatório de Biritiba-Mirim mostrou considerável crescimento, com cerca de $133,75 \%$, enquanto a área de asfalto e solo exposto aumentou $6,58 \%$.

Para Prado (2004) o aprimoramento das condições das rodovias antes e após a construção dos reservatórios, além da facilidade ao acesso hídrico, promoveram a crescente modernização agrícola do entorno do reservatório.

\section{6. Água versus Sedimento}

A análise das amostras mostrou distinção entre os resultados obtidos na análise química da água e os resultados obtidos na análise química dos sedimentos. $\mathrm{Na}$ avaliação da água, observou-se a presença dos elementos alumínio, ferro e manganês nas amostras coletadas na área com atividade agrícola próxima ao reservatório e nas amostras coletadas no ponto branco, em concentração acima do valor permitido pela legislação brasileira, elementos que não aparecem nos resultados da química de sedimentos.

Contudo, nos três casos, ou seja, amostras coletadas nos três locais de estudo, área com mata preservada, área com atividade agrícola no entorno do reservatório e no ponto referência, observa-se enriquecimento das amostras pelos elementos $\mathrm{P}_{2} \mathrm{O}_{5}$, $\mathrm{SO}_{3}, \mathrm{~K}_{2} \mathrm{O}, \mathrm{MnO}, \mathrm{CuO}, \mathrm{ZnO}$ e $\mathrm{PbO}$, não encontrados nas análises realizadas nas amostras de água coletadas. Tal aspecto pode indicar que houve entrada de elementos potencialmente tóxicos em período anterior a atual lâmina de água. Ou ainda uma provável contaminação remota desses sedimentos.

Não há explicação razoável para o elemento químico que aparece em um resultado e não no outro. Pode ser que a constituição química das rochas do entorno do reservatório estejam influenciando a composição da água e do sedimento, mas teríamos que realizar análise dessas rochas. 


\section{CONCLUSÃO}

Quanto aos parâmetros físico-químicos da água de algumas amostras, as alterações do $\mathrm{pH}$ e OD, podem corresponder ao despejo de matéria orgânica proveniente de aditivos agrícolas utilizados na agricultura no entorno do reservatório.

Quanto à água, esperava-se e contatou-se que as amostras CAL estão dentro dos valores referenciados pelos parâmetros analisados, CONAMA 357/2005, MS 2914/2011 e MS 045/2014. Em algumas amostras CAS os elementos alumínio, ferro e manganês mostraram concentração acima do valor permitido pelas legislações em questão. Pode ser que esses elementos sejam provenientes da atividade agrícola ou da decomposição intempérica das rochas do entorno do reservatório e migração dos elementos mais solúveis das mesmas para seu interior.

Esperava-se que as amostras coletadas no ponto referência não apresentassem qualquer variação, mas os elementos alumínio, ferro e manganês encontraram-se em concentração acima do valor permitido pela legislação brasileira. Pode ser que este fato associado à atividade agrícola a montante do ponto de coleta e/ou a composição química da rocha que compõe o sedimento. Talvez esses pontos de referência, que também são utilizados pelo órgão estadual SABESP, não sejam confiáveis quanto a esses parâmetros analisados nessa dissertação.

Quanto ao sedimento, nos três casos, ou seja, nas amostras CAL, CAS e ponto referência, observa-se enriquecimento pelos elementos $\mathrm{P}_{2} \mathrm{O}_{5}, \mathrm{SO}_{3}, \mathrm{~K} 2 \mathrm{O}, \mathrm{MnO}, \mathrm{CuO}$, $\mathrm{ZnO}$ e $\mathrm{PbO}$, sendo as amostras CAL mais enriquecidas que as CAS. Pode ser que a composição das amostras, em sua maioria argila/silte e areia muito fina permita maior retenção desses elementos químicos. Cabe destacar que esses elementos em sua maioria são elementos utilizados fertilizantes e defensivos empregados na agricultura da região.

Esperava-se que as amostras CAS estivessem mais enriquecidas por elementos químicos, quando comparada as amostras CAL. Pode ser que a grande quantidade de aguapés presentes no reservatório esteja retendo esses elementos químicos. Também pode-se atribuir ao vento, de Sul para Norte, que através da movimentação constante das águas, carregue os elementos químicos da área CAS para a CAL. 
Pode-se dizer que nas amostras analisadas, não há comprometimento ambiental quanto ao elemento fósforo (P) segundo CONAMA 344/2004, já que os valores não atingem o máximo permitido pela resolução em questão. Assim como para o elemento cobre $(\mathrm{Cu})$, quando comparado aos valores obtidos nas amostras com os quatro parâmetros analisados.

Quanto ao uso e ocupação do solo, percebe-se que houve um crescimento exagerado da horticultura no entorno do reservatório de Biritiba-Mirim, cerca de $133,75 \%$, assim como um aumento de área de asfalto, que pode ser decorrente da melhoria das condições das rodovias, da facilidade ao acesso hídrico e da modernização agrícola do entorno do reservatório. Ao mesmo tempo, a diminuição das áreas de silvicultura e mata atlântica mostram a necessidade de uma maior área disponível para a atividade hortifrutigranjeira.

Conclui-se que hoje não há um gerenciamento adequado do uso e ocupação do solo no entorno dos reservatórios de captação de água para abastecimento público, como é visto nos reservatórios que compõem o sistema produtor do Alto Tietê. No entanto, a fim de evitarmos futuros problemas ambientais, como por exemplo, a contaminação e o comprometimento do solo e das águas desses reservatórios, tornando a água imprópria para o consumo e causando, principalmente, o desabastecimento das grandes cidades, como o que vem acontecendo nos anos de 2014 e 2015, deve haver uma melhor gestão dos recursos hídricos, que proiba o manejo inadequado do solo e que proteja as áreas de mananciais e a mata ciliar do entorno dos reservatórios. 


\section{REFERÊNCIAS BIBLIOGRÁFICAS}

ALlOWAY, B. J.; AYRES, D. C. 1997. Chemical Principles of Environmental Pollution, 2 ed. Ed. Chapman \& Hall, New York.

ASSEMBLÉIA LEGISLATIVA DO ESTADO DE SÃO PAULO - Lein ${ }^{\circ} 1.172$, de 17/11/1976 - Delimita as áreas de proteção relativas aos mananciais, cursos e reservatórios de água. Disponível em: http://www.al.sp.gov.br/norma/?id=29141

BAGLI, V. V. 2005. Mosaico de imagens de sensoriamento remoto. Proposta de dissertação de mestrado em computação aplicada. Faculdade de Ciência e Tecnologia, Instituto Nacional de Pesquisas Espaciais. São José dos Campos.

BARROS, F. G; AMIM, M. M. 2008. Água: um bem econômico de valor para o Brasil e o Mundo. Revista Brasileira de Gestão de Desenvolvimento Regional. v.4, n.1, p.75-108, janabr, Taubaté, SP, Brasil.

BOTTINO, F; CALIJURI, M; Calijuri,; MURPHY, KEVIN JOSEPH . Temporal and spatial variation of limnological variables and biomass of different macrophyte species in a Neotropical reservoir (São Paulo - Brazil). Acta Limnologica Brasiliensia (Online), v. 25, p. 387-397, 2013.

CARVALHO, A . R; SCHLITTLER, F. H. M; TORNISIELO, V. L. 2000. Relações da atividade agropecuária com parâmetros físico químicos da água. Química Nova, v. 5, p. 23.

CASAGRANDE, L. A. R.; SALVADOR, N. N. 2007. Uso de Insumos Agrícolas $e$ Ocorrência de Nitrato nas Águas Subterrâneas. In: CONGRESSO DE PÓS-GRADUAÇÃO, 4., 2007, São Carlos, Anais de Eventos da UFSCar, v. 3, p. 1793.

CAVALCANTI, M. A. M. P. 2002. A modelagem matemática associada ao sistema de informação geográfica como instrumento de previsão no estudo do impacto hidrogeológico de reservatórios. Tese de Doutoramento, Instituto de Geociências, Universidade de São Paulo, p. 142.

CCN - PLANEJAMENTO E ENGENHARIA S/C Ltda. 1997. Estudo de impacto ambiental. Sistema produtor Alto Tietê. Barragens de Biritiba-Mirim, Paraitinga e complementação Taiaçupeba. São Paulo. v. 2, p. 134. Relatório DAEE.

COMPANHIA AMBIENTAL DO ESTADO DE SÃO PAULO - CETESB. 2004. Histórico da Legislação Hídrica no Brasil. Disponível em: http://www.cetesb.sp.gov.br. Acesso em 13 de janeiro de 2015.

COMPANHIA AMBIENTAL DO ESTADO DE SÃO PAULO - CETESB. 2014. ARTIGO 1o DA DECISÃO DE DIRETORIA no 045/2014/E/C/I, DE 20 DE FEVEREIRO DE 2014 Publicada no DOU no 045, de 20/02/2014, p. 53 - Valores Orientadores para Solos e Águas Subterrâneas no Estado de São Paulo - 2014, em substituição aos Valores Orientadores de 2005.

COOKE, G.D.; WELCH, E.B; PETERSON, S.A.; NICHOLS, S.A. 2005. Restoration and management lakes and reservoirs. CRC. 584p. 
CPRM - Companhia de Pesquisas de Recursos Minerais. 1990. Projeto Santa Isabel / Mogi das Cruzes / Mauá - Relatório Final. Companhia de Pesquisas de Recursos Minerais. Pró Minério. v. 1 e 2. São Paulo.

DEPARTAMENTO DE ÁGUAS E ENERGIA ELÉTRICA - DAEE. 1975. Estudo de Águas Subterrâneas, Região Administrativa 1-Grande São Paulo. São Paulo. SOMA. v. 3, p. 220.

ESTEVES, F. A. 1998. Fundamentos de Limnologia. 2a Ed. - Rio de Janeiro : Interciência FILHO, W. P; CORAZZA, R; WACHHOLZ, F; TRENTIN, A. B; KRAMER, G; Barbosa, C. C. F. 2009. Influência de reservatórios em cascata nos dados de reflectância e de limnologia - reservatório de Passo Real e Dona Francisca, RioJacuí - RS. ANAIS XIV Simpósio Brasileiro de Sensoriamento Remoto, Natal, Brasil, 25-30 Abril, INPE, p. 4813-4819.

HORTELlANI, M. A; JORGE, E. S. S; ABESSA, D. M. S; SOUSA, E. C. P. M.2008.Avaliação da contaminação por elementos metálicos dos sedimentos do estuário Santos - São Vicente. Química Nova, v. 31, no.1, p. 10-19.

Instituto Nacional de Pesquisas Espaciais. Manuais do Sistema de Processamento de $\begin{array}{lll}\text { Informações } & \text { Georreferenciadas } & \text { (SPRING). }\end{array}$ Disponívelem:http://www.dpi.inpe.br/spring/portugues/manuais.html Acesso em: Janeiro de 2014.

JESUS, H. C; COSTA, E. A: MENDONÇA, A. S. F; ZANDONALE, E. 2004. Distribuição de metais pesados em sedimentos do sistema estuarino a ilha de Vitória - ES. Química Nova, v. 27 , no 3 , p. 378-386.

LEI $\mathrm{N}^{\mathbf{0}}$ 9.433, de 8 de Janeiro de 1997. Disponível em www.planalto.gov.br/ccivil_03/leis/19433.htm. Acesso em 13 de janeiro de 2014.

LIMA, A. M; SANTOS, F. F. 2013. Análise das propriedades físico-químicas e de metais potencialmente tóxicos na água do Rio Claro, próximo a Cidade de Jataí - GO. Revista Ciências Exatas e naturais, v.14, n.2, Jul/Dez.

MINISTÉRIO DA SAÚDE PORTARIA N. 518, DE 25 DE MARÇO DE 2004. Controle e vigilância da qualidade da água para consumo humano e seu padrão de potabilidade. Disponíve em: http://www.cetesb.sp.gov.br/userfiles/file/agua/legislacao/federal/port$\underline{\text { 51825032004.pdf }}$

MONTEIRO, M. D. 2006. Avaliação do conteúdo de metais e defensivos agrícolas na área de influência do reservatório de Biritiba-Mirim (SP). 2006. 47f. Trabalho de Formatura. Instituto de Geociências. Universidade de São Paulo, São Paulo, 2006.

MORAES, E. C. 2002. Fundamentos de sensoriamento remoto - capítulo 1. Instituto Nacional de Pesquisas Espaciais (INPE). São José dos Campos.

MORAIS, L. V; AMADOR, M. B. M. 2011. Uso da terra no entorno da represa CajaranaDistrito de São Pedro em Guaranhuns - PE. Revista científica ANAP Brasil, v.4, n.4. Julho.

NOGUEIRA, R. N; SILVEIRA, R. J; PEREIRA, R. S. 1997. Georreferenciamento de mapas temáticos e imagens de satélite no aplicativo IDRISI. Rev. Bras. de agrociência, v.3, n.3, p. 99-106, set-dez. 
NÚÑEZ, J. E. V; SOBRINHO, N. M. B; MAZUR, N. 2006. Consequências de diferentes sistemas de preparo do solo sobre a contaminação do solo, sedimentos e água por metáis pesados. Edafologia, v. 13, n.2, p 73-85.

PEREIRA, L. S. 2008. Evolução espaço - temporal do uso e cobertura da terra e qualidade da água do Ribeirão Piancó - Anápolis - Goiás. Dissertação de mestrado apresentada à Universidade Estadual de Goiás.

PIRES NETO, A. G.1992. Abordagens sintético-histórica e analítico-dinâmica: uma proposição metodológica para a geomorfologia. Tese de Doutorado - Faculdade de Filosofia, Letras e Ciências Humanas, Universidade de São Paulo. p. 332.

PRADO, R. P. 2004. Geotecnologias aplicadas à análise espaço temporal do uso e cobertura da terra e qualidade da água do reservatório de Barra Bonita, SP, como suporte à gestão de recursos hídricos. Tese apresentada à escola de engenharia de São Carlos para obtenção do título de doutor. São Carlos, SP.

PREFEITURA MUNICIPAL DE BIRITIBA-MIRIM - PMBM. Disponível em: <http://www.biritibamirim.sp.gov.br>. Acesso em 15 de maio de 2014.

POLÍTICA NACIONAL DE RECURSOS HÍDRICOS - LEI N $\mathrm{N}^{\circ}$ 9.433, DE 8 DE JANEIRO DE $1997 . \quad$ Disponível em: http://www.planalto.gov.br/ccivil 03/leis/L9433.HTM. Acesso em 14 de maio de 2014.

PORTARIA No 2914, DE 12 DE DEZEMBRO DE 2011 MINISTÉRIO DA SAÚDE. Qualidade da água para consumo humano. Diponível em: http://site.sabesp.com.br/uploads/file/asabesp_doctos/kit_arsesp_portaria2914.pdf

PREFEITURA MUNICIPAL DE BIRITIBA-MIRIM - PMBM. Disponível em: $<$ http://www.biritibamirim.sp.gov.br<. Acesso em 13 de janeiro de 2014.

RESOLUÇÃO N. 357, DE 17 DE MARÇO DE 2005 PUBLICADA NO DOU NO 053, DE 18/03/2005, P. 58-63

ROSS, J. L. S; MOROZ, I. C. 1997. Mapa geomorfológico do Estado de São Paulo Laboratório de geomorfologia Depto de Geografia - FFLCH - USP/ Laboratório de Cartografia Geotécnica - Geologia Aplicada - IPT/FAPESP - Fundação de Amparo à Pesquisa do Estado de São Paulo.

SABESP/CEPAS/IGc-USP. 1994. Diagnóstico Hidrogeológico da Região Metropolitana de São Paulo. Diagnóstico Final. Convênio SABESP/CEPAS-IG/USP. São Paulo. p. 115.

SILVA R.T; PORTO M. F. A. 2003. Gestão urbana e gestão das águas: caminhos da integração. Estudos avançados v.17, n.47 - São Paulo Jan./Apr.

SOBRAL, M. C. M; CARVALHO, R. M. C. M. O; SILVA, M. M; MELO, G. L. 2006. Uso e ocupação do solo no entorno de reservatório no Semi-Árido brasileiro como fator deterinante da qualidade da água. XXX Congresso Interamericano de Iingeniería Sanitaria y Ambiental. Punta del Este - Uruguai.

SOUSA; C, 2013. Relação entre a qualidade da água e sedimentos no reservatório de Biritiba - Mirim -SP face ao uso do solo em áreas sob vegetação natural e áreas agrícolas - Exame de qualificação de doutorado - Procam, SP. p. 96 
SPERLING, M. V. 2005. Introdução à qualidade das águas e ao tratamento de esgotos. Departamento de engenharia sanitária e ambiental - DESA Universidade Federal de Minas Gerais, v. 1 3A Edição,.

TEIXEIRA, E. C; FORMOSO, M. L. L; BINOTTO, R. B; SANCHEZ, J. D. 1999.Estudo do potencial de oxi-redução em águas subterrâneas que sofrem influência dos depósitos de rejeitos de carvão e cinas - Municípios do Rio Grande do Sul. Geochimica Brasiliensis v.13, n.1, p. 001-016.

TUNDISI, J. G. 2008. Recursos hídricos no futuro: problemas e soluções. Estudos avançado v. 22 , p. 63. 